\title{
Attic or Roof? An Evaluation of Two Advanced Weatherization Packages
}

K. Neuhauser

Building Science Corporation 


\section{NOTICE}

This report was prepared as an account of work sponsored by an agency of the United States government. Neither the United States government nor any agency thereof, nor any of their employees, subcontractors, or affiliated partners makes any warranty, express or implied, or assumes any legal liability or responsibility for the accuracy, completeness, or usefulness of any information, apparatus, product, or process disclosed, or represents that its use would not infringe privately owned rights. Reference herein to any specific commercial product, process, or service by trade name, trademark, manufacturer, or otherwise does not necessarily constitute or imply its endorsement, recommendation, or favoring by the United States government or any agency thereof. The views and opinions of authors expressed herein do not necessarily state or reflect those of the United States government or any agency thereof.

Available electronically at http://www.osti.gov/bridge

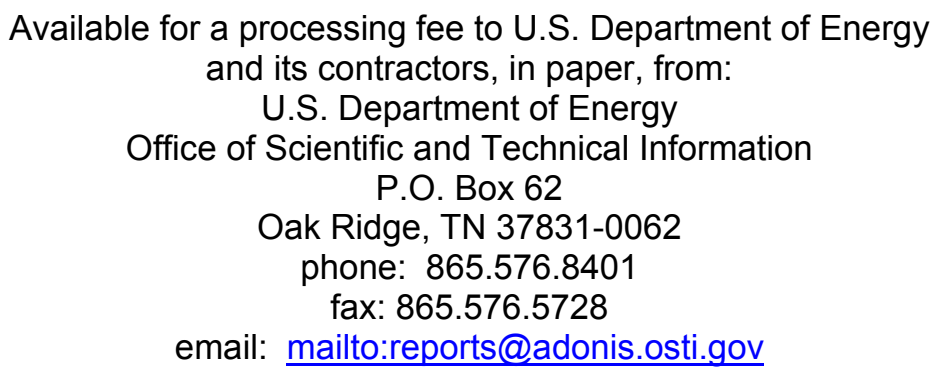

Available for sale to the public, in paper, from:

U.S. Department of Commerce

National Technical Information Service

5285 Port Royal Road

Springfield, VA 22161

phone: 800.553 .6847

fax: 703.605 .6900

email: orders@ntis.fedworld.gov

online ordering: http://www.ntis.gov/ordering.htm 


\title{
Attic or Roof? An Evaluation of Two Advanced Weatherization Packages
}

\author{
Prepared for: \\ Building America \\ Building Technologies Program \\ Office of Energy Efficiency and Renewable Energy \\ U.S. Department of Energy
}

Prepared by:

Ken Neuhauser

Building Science Corporation

30 Forest Street

Somerville, MA 02143

NREL Technical Monitor: Cheryn Engebrecht

Performed Under Subcontract No. KNDJ-0-40337-00

June 2012 
[This page left blank] 


\section{Contents}

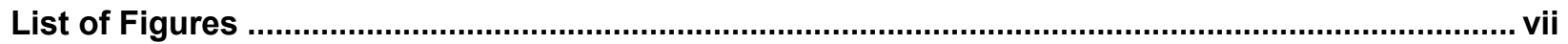

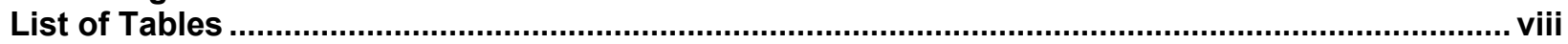

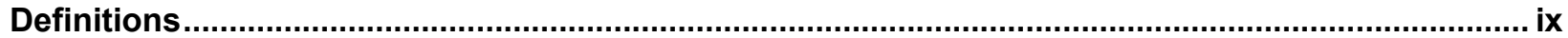

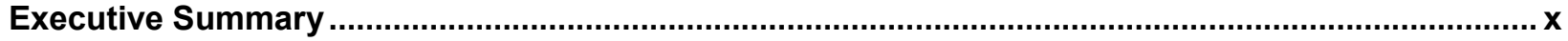

1 Introduction .

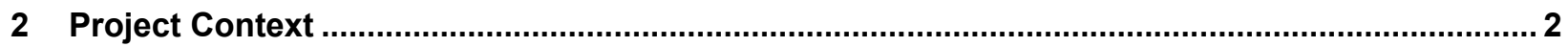

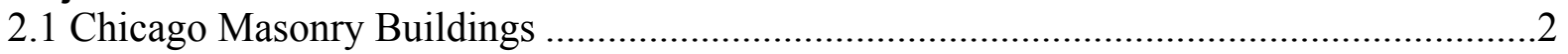

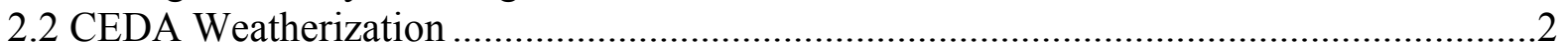

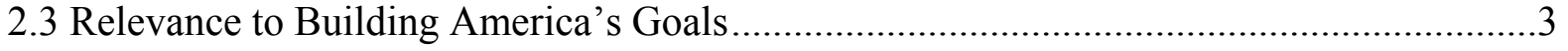

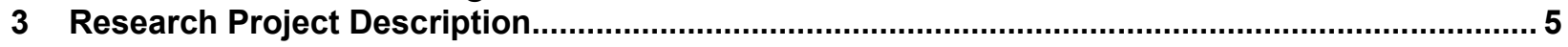

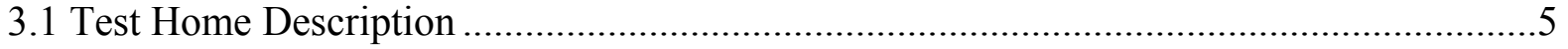

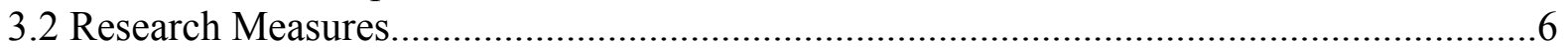

3.2.1 Attic Deck Insulation and Air Ssealing ....................................................

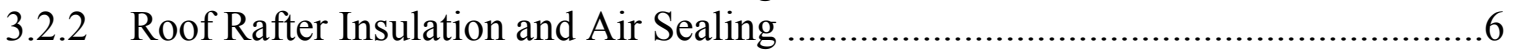

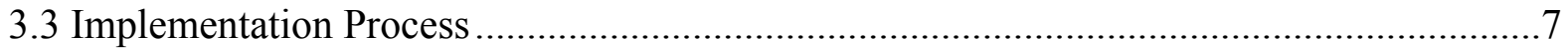

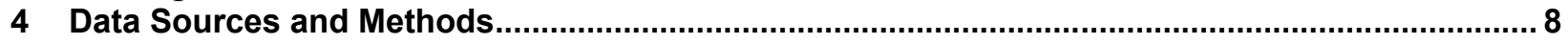

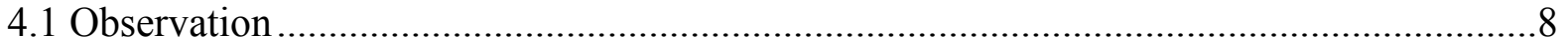

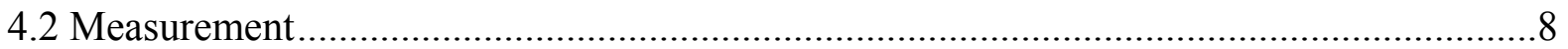

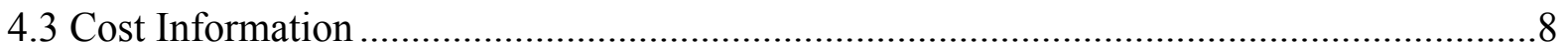

4.4 Limitations of Performance Measurement............................................................. 8

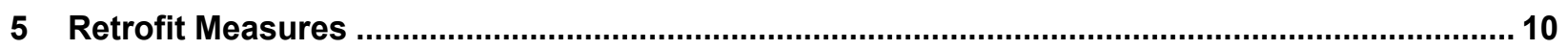

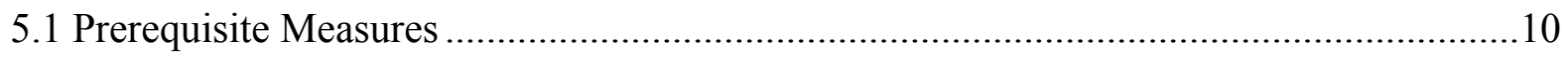

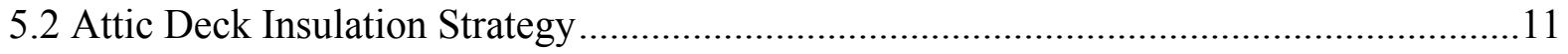

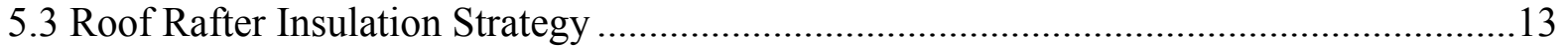

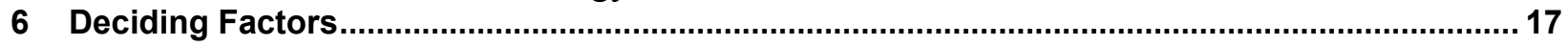

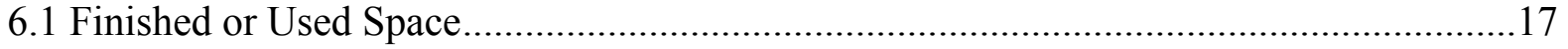

6.2 Access for Air Sealing at Attic Floor.................................................................. 17

6.3 Feasibility of Air Sealing and Insulation at Attic Access .............................................. 18

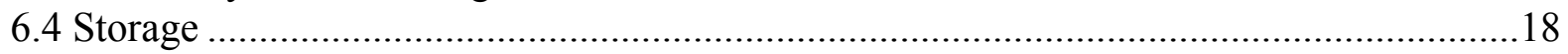

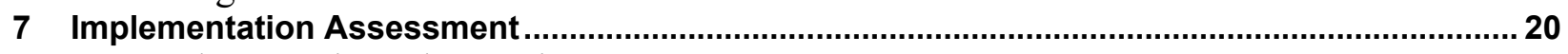

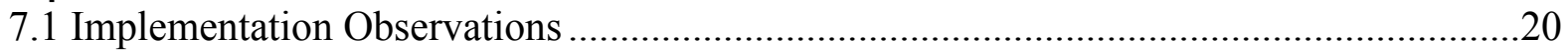

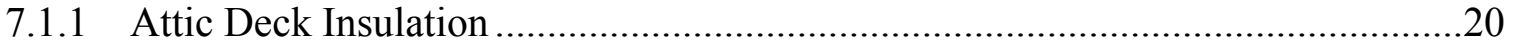

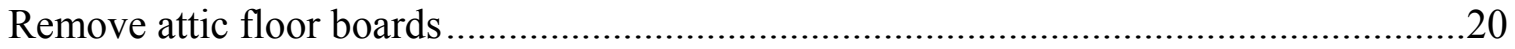

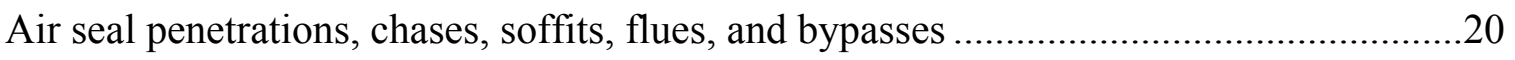

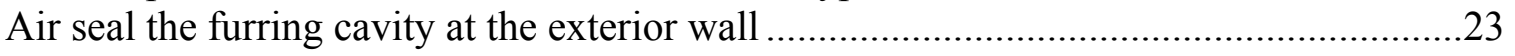

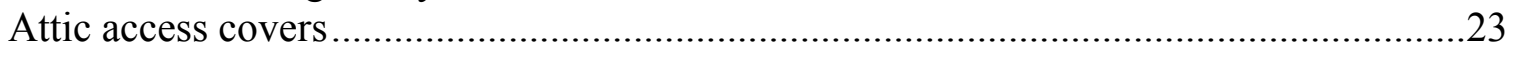

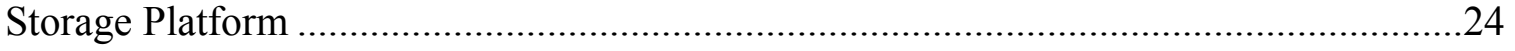

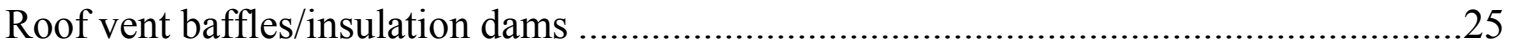

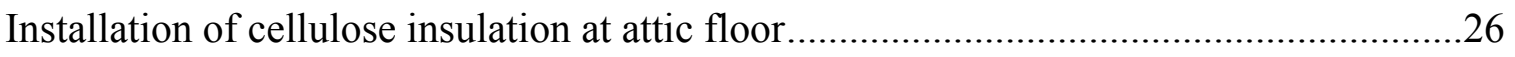

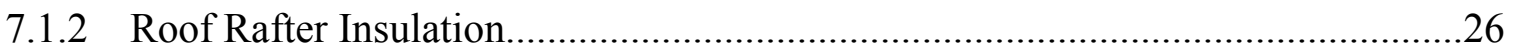

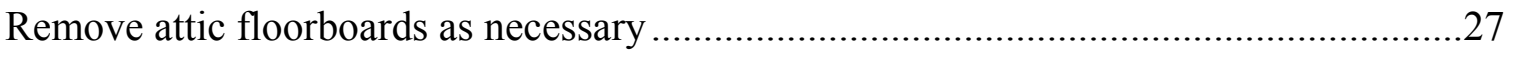

Rigid insulation transition piece from top of wall to underside of roof sheathing ............27

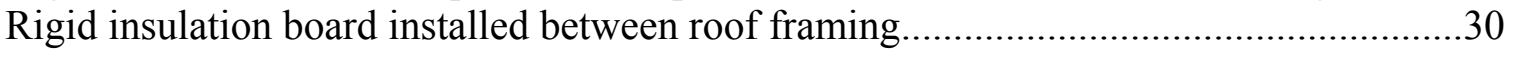

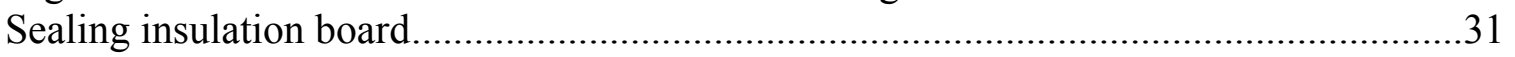

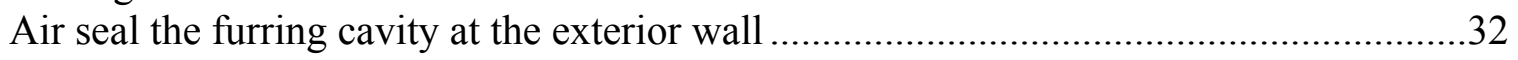

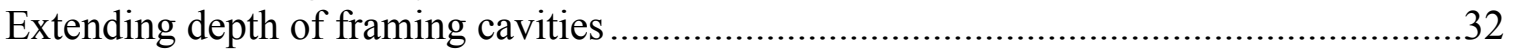




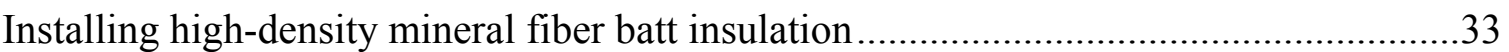

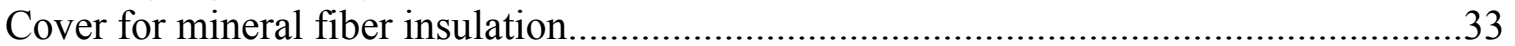

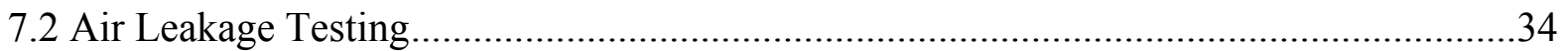

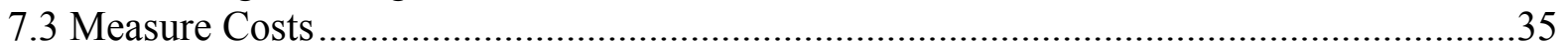

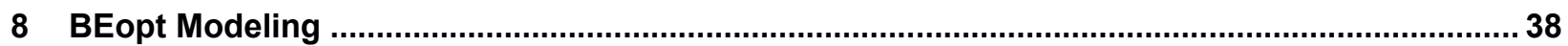

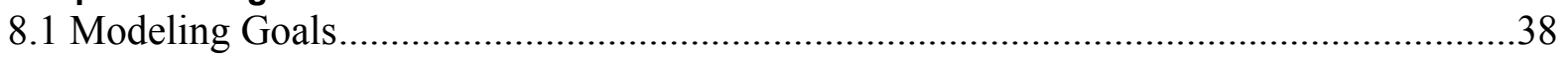

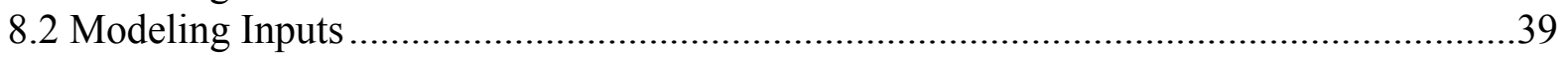

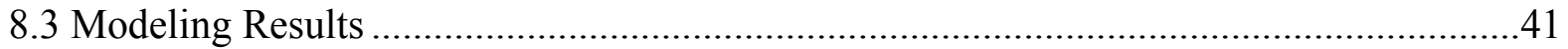

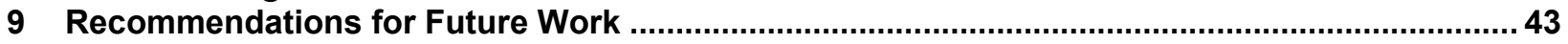

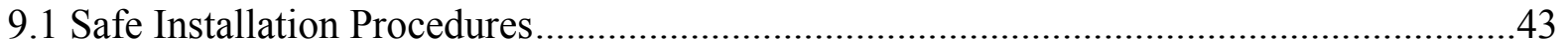

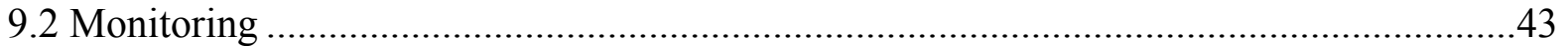

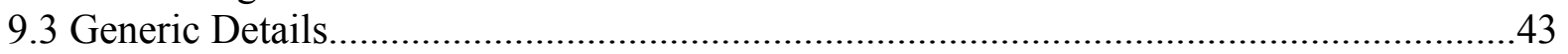

9.4 Alternate Strategies to Unvented Roof Retrofit..........................................................43

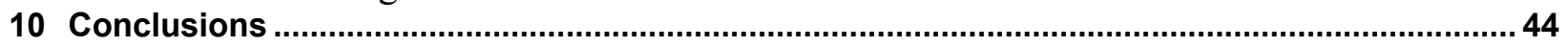

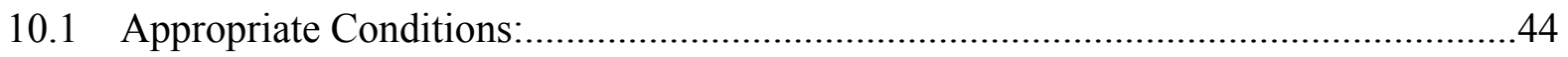

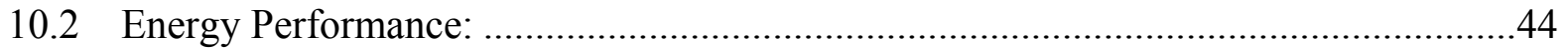

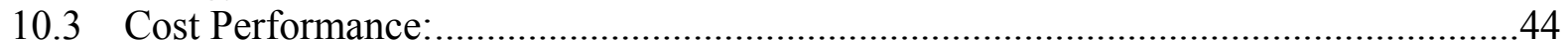

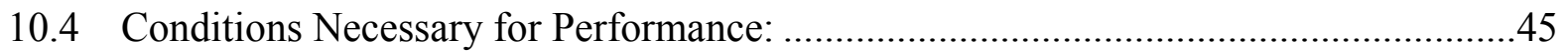

10.5 Conditions Necessary for Wider Adoption:...........................................................46

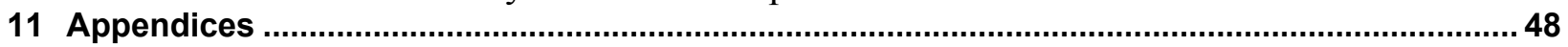

11.1 Appendix A: Sample work scope guidance memo .............................................48

11.2 Appendix B: Sample work order proposal.....................................................50

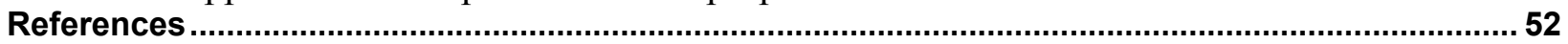




\section{List of Figures}

Figure 1. Typical Chicago brick bungalows ................................................................................... 5

Figure 2. Furring cavity between brick masonry and interior finish as seen from the attic ............. 12

Figure 3. Left: Attic floorboards removed to investigate conditions at top of wall during assessment of prototype house; Right: Attic floorboards removed to allow access to top of wall

Figure 4. Foil-faced polyisocyanurate board insulation installed to transition thermal control from top of masonry wall to roof. The rigid insulation board rests on top of a wood plate at the top of the brick wall. Note that furring cavity gap (at junction of wall plaster and ceiling plaster) is to interior side of the rigid board insulation as indicated by wood furring extending above the top of the brick wall.

Figure 5. Foil-faced polyisocyanurate insulation board with seams and joints sealed to adjacent framing.

Figure 6. Foil-faced polyisocyanurate insulation board between roof rafters and transitioning to top of wall with seams and joints to adjacent framing sealed.....

Figure 7. Finished room in attic of House 1 (Photo credit: E. Haber, printed with permission)....... 17

Figure 8. Left: Attic floorboards partially removed for attic deck air sealing and insulation; Right: Attic floorboards removed intact (Photo credit: S. Marchese, printed with permission) ........... 20

Figure 9. Left: Creating access to dropped soffit area and plumbing wall; Right: Attic floorboard repurposed in sealing plumbing chase (Photo credit: S. Marchese, printed with permission). 20

Figure 10. Bath fan housing cover encased in foam sealant (red arrow) and electrical junction box surrounded by metal insulation dam (blue arrow).

Figure 11: Left: Images from "Attic Air Sealing Guide and Details" showing steps for treatment of exhaust fan housing; Right: Images from this guide showing steps for treatment of electric junction box

Figure 12. CEDA Weatherization assessing effectiveness of air seal at furring cavity between brick masonry and interior finish (Photo credit: S. Marchese, printed with permission) .................... 22

Figure 13. Left: Corner of attic access hatch insulation dam and frame; Right: Attic hatch insulated but without gaskets

Figure 14. Hinged attic hatch with counterweight over attic access stairs. Gaskets and weather

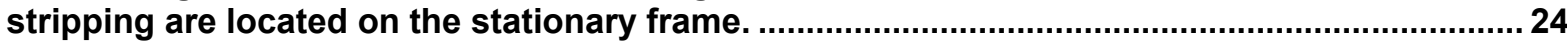

Figure 15. Storage platform framing (Photo credit: S. Marchese, printed with permission) ............ 24 Figure 16. Left: Attic storage platform with insulation dams at the perimeter; Right: A CEDA Weatherization team member checks the depth of insulation beneath platform ....................... 25

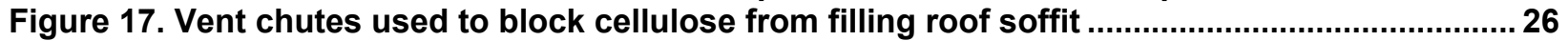

Figure 18. Left: Workers cutting access cut to expose top of exterior wall and furring cavity; Right: Access cut to expose top of exterior wall and furring cavity at inset opening (Photo credit: $S$. Marchese, printed with permission).

Figure 19. Foil-faced polyisocyanurate insulation notched around roof and ceiling framing (Photo credit: E. Haber, printed with permission)

Figure 20. Left: Framing added above exterior wall at inset entry; Right: rigid board insulation installed to transition thermal control from exterior wall to roof assembly...............................28

Figure 21. Left: Small space with limited access at face of dormer. Right: section of interior finish removed to allow air sealing (Photo credit: E. Haber, printed with permission)..

Figure 22. Foil-faced polyisocyanurate insulation installed above ceiling of finished room in attic (Photo credit: E. Haber, printed with permission)...

Figure 23. Foil-faced polyisocyanurate insulation fit into rafter framing cavities (Photo credit: $S$. Marchese, printed with permission)

Figure 24. Foam sealant applied to seal foil-faced polyisocyanurate to surrounding framing. In this image the application of rigid insulation and foam sealant is not complete. (Photo credit: E. Haber, printed with permission).

Figure 25. Left: Extruded polystyrene and wood furring strip used to extend rafter cavity; Right: Attic with rafter cavities extended in preparation for mineral fiber insulation (Photo credit: $S$. Marchese, printed with permission). 
Figure 26. High density fiberglass batt in extended rafter cavity; Right: Completed roof rafter strategy (Photo credit: $S$. Marchese, printed with permission)

Figure 27. Air leakage reduction for attic deck and roof rafter strategies ....................................... 34

Figure 28. BEopt image of representative house model.................................................................... 38

Figure 29. Source energy use bar graph of 4-scenario BEopt modeling results showing the preretrofit case, the programmable T-stat, bath exhaust, and crawlspace insulation step, and the two roof insulation options

Figure 30. Costs-to-savings plot of 4-scenario BEopt modeling results showing the pre-retrofit case, the programmable T-stat, bath exhaust, and crawlspace insulation step, and the two roof

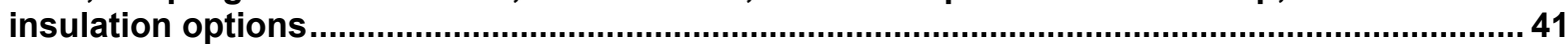

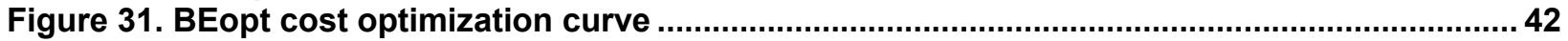

Unless otherwise noted, all figures and images were provided by Building Science Corporation.

\section{List of Tables}

Table 1. Summary of Common Decision Factors at Test Homes

Table 2. Attic Floor Insulating and Air Sealing Strategy Cost Components...................................... 35

Table 3. Roof Rafter Insulating and Air Sealing Strategy Cost Components ................................... 36

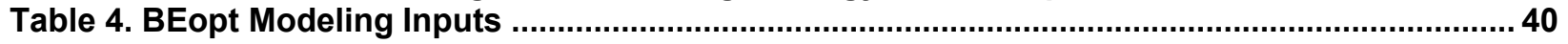

Unless otherwise noted, all tables were provided by Building Science Corporation. 


\section{Definitions}

$\mathrm{ACH} 50$

Building air changes per hour induced by a relative pressure difference of 50 Pascals between the building and ambient conditions

BSC

Building Science Corporation

$\operatorname{ccf}$

One hundred cubic feet. This is a measure generally applied to natural gas.

CEDA

Community and Economic Development Association of Cook County, Incorporated

CEDA Wx

CEDA Weatherization, a division of CEDA

DOE

United States Department of Energy

$\operatorname{cfm} 50$

Air flow, through an enclosure or assembly induced by a relative pressure difference of 50 Pascals across the enclosure or assembly

IAQ Indoor air quality

IHWAP Illinois Home Weatherization Assistance Program

$\mathrm{Pa} \quad$ Pascals (unit of pressure)

SIR Savings-to-Investment ratio.

SPF Spray-applied Polyurethane Foam

Wx Weatherization 


\section{Executive Summary}

This project examines implementation of advanced retrofit measures in the context of a largescale weatherization program and the archetypal Chicago, Illinois, brick bungalow. In response to the apparent weatherization program limitations with respect to homes with masonry bearing wall construction, this research project examines two distinct strategies for insulating and air sealing the top of houses. One strategy applies best practice air sealing methods and a standard insulation method to the attic floor. The other strategy creates an unvented roof assembly using materials and methods typically available to weatherization contractors.

Through implementation of the retrofit strategies in a total of eight (8) test homes, the research found that the two different strategies achieve similar air leakage and energy performance improvement relative to the pre-retrofit conditions despite the fact that the unvented roof strategy encloses a larger volume and results in a larger thermal enclosure area. Average air leakage measure reductions were approximately $55 \%$ for both strategies. Energy modeling predicts source energy use reductions of roughly $18 \%$ for both strategies.

The cost for the unvented, roof rafter insulation approach was found to be about $\$ 7,000$ more than air sealing and insulating at the attic floor. However, the roof rafter insulation strategy could also be viewed as a very cost-effective strategy to increase-by roughly $50 \%$ - the usable abovegrade conditioned floor area.

Through observations of the strategies implemented, the research described in this report identifies measures critical to performance as well as conditions for wider adoption. The research also identifies common factors that must be considered in determining the appropriate strategy for the top of the building. 


\section{Introduction}

The predominant construction types for residential structures in Chicago, Illinois, involve loadbearing masonry walls. Methods to insulate these wall assemblies are beyond the reach of typical weatherization programs. Yet, the need for weatherization in these masonry buildings is clearenergy costs are an increasing burden on household incomes. Given the wall assembly of these buildings, the most promising opportunities for weatherization to achieve significant benefits for residents of these masonry-walled structures appears to be at the top of the building: either in the attic or at the roof.

A typical measure to reduce heat loss at the top of the building is to apply loose cellulose or fiberglass batt insulation at the attic floor. Reducing heat loss at the top of the building, especially in a cold climate like Chicago, is particularly dependent on controlling convective losses (air leakage). Common conditions of attic or roof assemblies make it very difficult to achieve effective air leakage reduction at the top of the building. There are also common conditions - such as occupied, finished and heated rooms in attic spaces - that make insulation at the attic floor inappropriate.

This research project evaluates two strategies for insulating and air sealing at the top of masonry bungalow houses in a sample of one-story brick bungalow homes eligible to participate in the Community and Economic Development Association of Cook County (CEDA) Weatherization program. One strategy involves recognized "best practices" applied to attic floor insulation (Lstiburek, 2010). The other involves insulating and air sealing in the plane of roof rafters. The later strategy is developed as part of the research effort. The research also identifies conditions under which roof rafter or attic deck strategies are appropriate. The strategies are further evaluated in terms of air flow control, feasibility and cost. 


\section{Project Context}

\section{Chicago Masonry Buildings}

Masonry buildings are the dominant building type of residential structures in Chicago. While this may be expected for large older multifamily buildings, it is also true of smaller residential buildings in Chicago. According to Cook County Assessment Department data, 57\% of 1-unit housing stock and $58 \%$ of 2- to 4 -unit housing stock in Cook County is of masonry construction.

Illinois ranks second in the country in gas use per residential gas customer at 1,082 ccf/customer, behind only Alaska at 1,663 ccf/customer (AGA, 2010). Residential buildings in the Chicago area exhibit nearly $60 \%$ higher heating energy use than the Illinois state average (AGA, 2010).

\section{CEDA Weatherization}

The CEDA Weatherization programs serve income-eligible clients in Cook County, Illinois. CEDA Weatherization is one of over 30 community action agencies that participate in the Illinois Home Weatherization Assistance Program (IHWAP). The Illinois Department of Commerce and Economic Opportunity (DCEO) administers the program; DCEO's Office of Energy Assistance monitors all agencies in the IHWAP network.

The services that CEDA Weatherization provides are structured around a comprehensive energy audit performed by a CEDA Weatherization assessor. The audit assessment leads to development of a work order that may comprise measures in the following categories: ${ }^{1}$

- Retrofit measures: insulation, CFL lighting, refrigerator replacement, low-flow shower heads and faucet aerators, heating system replacement, window and door replacement.

- Air-sealing measures

- Health and safety measures (limited to $\$ 600$ per unit): handrails, fire extinguishers, gutters, downspouts, and decommissioning of unvented space heaters.

- Incidental repair measure (limited to $\$ 500$ per unit)

DOE Weatherization program funding requires that the entire building/house receive a savingsto-investment ratio (SIR) of 1 or greater before it can be weatherized. ${ }^{2}$ Software tools are used to estimate the savings from various measures. Costs per work item are established in the program. The state-level administration of IHWAP sets a limit of $\$ 5,200$ to the expenditure for each housing unit served. Approved contractors participating in the CEDA Weatherization programs implement the work scope. Upon completion of the work, CEDA Weatherization assessors conduct inspection of the work.

CEDA weatherizes all types of single-family and multifamily structures. In typical years, CEDA Weatherization has weatherized 3000-4000 housing units. With funding made available through the American Recovery and Reinvestment Act, budgeted volume of units has increased as follows:

2010: 7500 units,

\footnotetext{
${ }^{1}$ Note that the list of allowable measures in the program has changed slightly since the period of research.

${ }^{2}$ Typically, the value of savings is taken as the present value of recurring savings for a period of time at a standard discount rate. The present value of savings is then compared to the initial cost or investment of the measure.
} 
2011: 11,000 units, and

2012: 9000 units.

The high proportion of masonry buildings within its service territory creates a persistent challenge for CEDA Weatherization programs. An analysis of the programs found that energy use reductions achieved by weatherization activity in homes of masonry construction are typically $1 / 3$ less than what is achieved in wood-framed homes. It is certainly conceivable that this reflects the thermal performance of masonry wall assemblies and the lack of opportunity for improvement at levels of investment commensurate with typical weatherization programs. The furring cavity between the brick wall and interior finish does not provide adequate space for effective insulation, and interior wall build-out for insulation or insulation and re-cladding at the exterior would be prohibitively expensive.

Within limits of current means and methods and funding resources, the top of the building enclosure is likely to yield the best opportunities for improvement. Typical measures to reduce heat loss at the top of the building include applying loose cellulose or fiberglass batt insulation at the attic floor. It is well understood that controlling air leakage at the attic/roof plane is crucial to building energy performance and also has important impact on building durability and indoor air quality.

Implementing air flow control at the top of the building is fraught with challenges in typical Chicago building configurations. In one- to two-family structures where attics are often more accessible, flooring and storage of resident belongings would render it very difficult and expensive to implement air sealing at attic floor. There is also a high incidence of situations where establishing the thermal enclosure at the attic floor will not be appropriate. These situations include difficult access to critical areas for air sealing and finished or semi-finished space above the attic floor. Walk-up attic stairs are another common feature in Chicago homes that would compromise the level of performance achieved through attic air sealing and insulation due to air leakage and conduction.

In order for CEDA Weatherization and other programs in the Chicago area to achieve significant performance improvement in masonry buildings, alternatives to attic floor weatherization are needed.

\section{Relevance to Building America's Goals}

The goal of the U.S. Department of Energy's (DOE) Building America program is to reduce home energy use for existing homes by at least $15 \%$ compared to pre-retrofit energy use. For CEDA, such reductions in existing home energy use are imperative to maintaining housing affordability and quality of life for CEDA's constituents.

While the specific target of measures implemented through this research and the dominant target of CEDA Weatherization programs is to reduce energy costs and improve comfort in a heating dominated climate, demonstrated effective strategies for treating the top of the thermal enclosure (i.e. the attic and roof) are applicable in all regions of the country. This research demonstrates the effectiveness of measures outlined in "Attic Air Sealing Guide and Details" (Lstiburek, February 2010) and presents implementation guidance developed during the research effort. The demonstrated performance potential and implementation guidance produced by this research 
serves as a jumping off point for further advanced measures to address masonry building enclosures.

It is proposed that subsequent research evaluate strategies to dramatically improve the thermal performance of load-bearing masonry walls and installation of high performance windows. Such advanced measures cannot reasonably be pursued before "lower hanging fruit" such as that addressed in this research is captured. The implementation guidance developed through this research will ensure that top-of-building strategies accommodate future measures to address other components of the thermal enclosure. 


\section{Research Project Description}

CEDA Weatherization was able to secure special funding for a limited research project that allowed for a project budget of $\$ 15,000$ (as compared to $\$ 5,200$ in the regular weatherization program) in each of 10 homes. To implement this research project, CEDA Weatherization joined with BSC in a Building America research partnership. This allowed BSC to participate as the technical lead in the research project.

Upon establishing a Building America research partnership, CEDA Weatherization and BSC conducted planning meetings that identified many research needs. Analysis of the building stock within CEDA Weatherization service territory and of program performance led the research partnership to focus on one dominant housing type, the one-story brick bungalow, and on one component of the thermal enclosure, the attic/roof. The basic outline of this research project is to identify appropriate strategies, implement these in a sample of 10 test homes through a controlled process and evaluate the strategies by various parameters.

\section{Test Home Description}

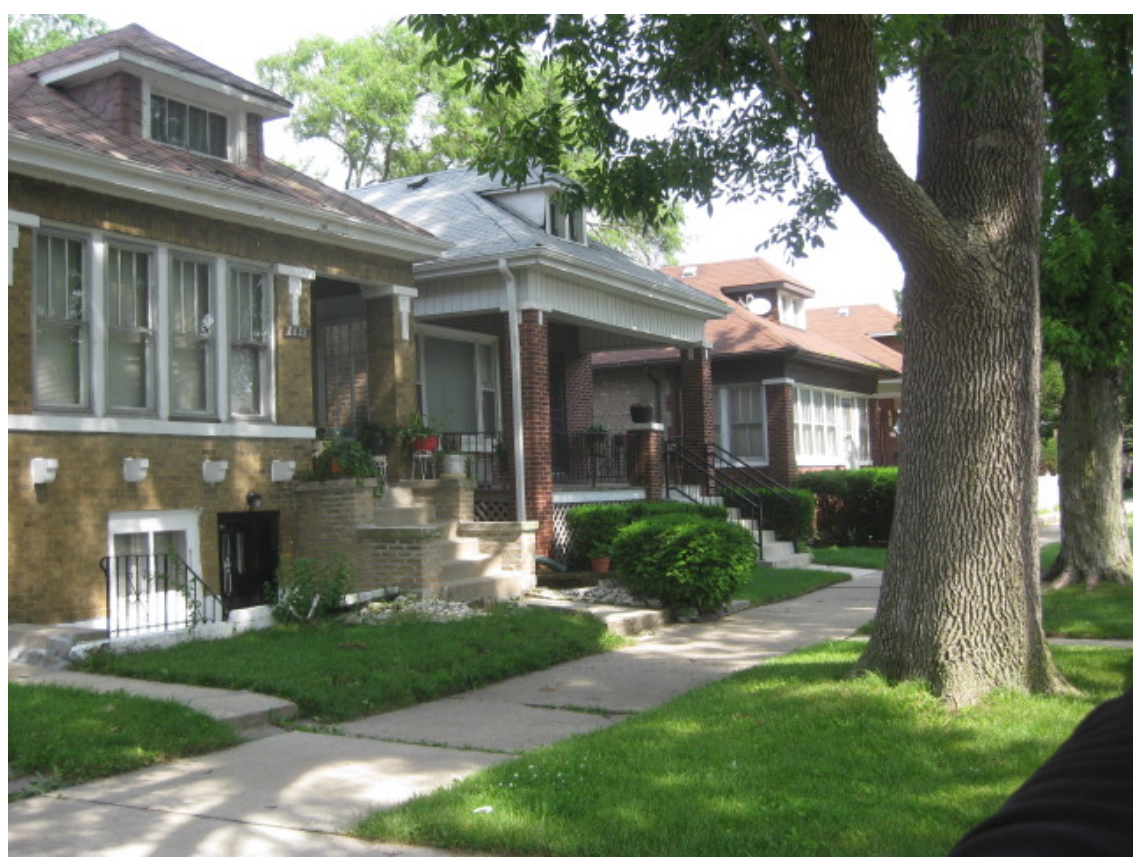

Figure 1. Typical Chicago brick bungalows

The test homes selected for this research project are all one-story bungalow-style homes with brick masonry bearing walls, full basements, and cast concrete or concrete block foundations. The homes have between 925 and 1,700 s.f. of conditioned living area on the first floor. The median value for conditioned floor area in the sample of test homes is 1,152 s.f.; the average is 1,216 s.f.

Most of the homes have a walk-up attic while one of the test homes has a scuttle hatch access to the attic. The attics typically have some older loose-blown insulation at the attic floor. While 
some of the test homes have deliberate roof vents in the form of either mushroom vents, turbine vents, or ridge vents, ventilation intakes are, for the most part, incidental. All but the test home with scuttle hatch access have some kind of wood floor boards (apparently original to the house) at the attic floor.

A lightly framed rear porch that has been enclosed sometime after original construction to provide additional four-season living space is typical to the Chicago brick bungalow. In a few cases observed, the porch was operated as an unconditioned space. The porch may be supported either on posts or a foundation wall. Even where the porch is supported on posts, siding and sheathing are typically carried down to a curb or grade level. Thus, there is typically a crawlspace or second basement beneath the rear porch space.

Another typical aspect of the test home type is an entry at the front, rear, or both that is inset relative to the footprint of the building. This creates an overhang of the roof and attic above the entry. Where there is an inset front entry, the inset occurs inside of the foundation walls such that there is a space in the basement with entry stairs and landing above. Often this space is separated from the rest of the basement as a closet or storage room.

Basements typically contain at least some finished or partially finished areas. A recreation room with a bar is not an uncommon feature. In some of the test homes, portions of the basement were clearly being used as sleeping areas. The majority of test homes have a history of periodic basement flooding.

\section{Research Measures}

\subsubsection{Attic Deck Insulation and Air Sealing}

A thermal measure commonly delivered through CEDA Weatherization programs is addition of insulation to the attic floor. The measure may or may not be accompanied by aggressive air sealing measures. In order to provide a reasonable basis of comparison between strategies, it was determined to enhance typical measures with "best practice" measures. The research strategy was to push this relatively familiar attic floor air sealing and insulation approach as far as reasonably feasible through the comprehensive air sealing measures such as outlined in the "Attic Air Sealing Guide and Details" (Lstiburek, February 2010) and developed in the course of the research.

\subsubsection{Roof Rafter Insulation and Air Sealing}

Because there are situations where proper insulation and air sealing of the attic floor is either impractical or inappropriate, the partnership determined that a solution that brought the attic space inside the thermal enclosure is needed. To devise an appropriate approach around insulating and air sealing in plane with the roof (enclosing the attic within the thermal barrier) BSC and CEDA assembled a group of recognized experts in the field of building performance and weatherization. This team met in Chicago over a period of three days to assess opportunities and evaluate initial implementation within a subject home identified by CEDA. CEDA also arranged for one of the weatherization program contractors to be on hand to advise on measure feasibility. CEDA Weatherization technical staff and consultants also performed blower door testing to assess building performance before and after different measures were implemented. This multiday operation resulted in a scope of work for the roof rafter strategy implemented in the research project. 


\section{Implementation Process}

The identified research measures were implemented through CEDA Weatherization program delivery channels. While the test homes in the research exhibit one of two thermal improvement strategies for the top of the building, the weatherization program scope also involves other thermal and energy efficiency measures. This prevented the isolation of attic floor or roof rafter insulation performance impact, though some insights can be gained from energy modeling (Section 8).

CEDA selected a contractor who had previously demonstrated success in CEDA's Weatherization program to perform all of the work relevant to the research project. This allowed for a greater level of consistency between different strategies implemented.

An outline of the process for implementing research measures in test homes is as follows:

1. CEDA Weatherization identifies potential test home candidates through analysis of customer data and program intake screening processes.

2. Designated technical and training staff conduct in-field assessments of prospective test homes. If the home appears to be a viable subject for either of the two research strategies, detailed data is collected, air leakage testing is performance, and preliminary work orders are prepared.

3. CEDA-BSC research team members review data collected for the prospective research test home and determine which of the two research strategies is appropriate for the home.

4. CEDA Weatherization technical staff finalize work scopes, BSC provides supplemental work scope guidance if needed.

5. Research strategy is implemented, as well as other weatherization measures by the designated program contractor. CEDA Weatherization staff provide implementation oversight.

6. CEDA Weatherization technical staff perform post-work measurement of air leakage.

7. CEDA-BSC teams perform analysis of cost, air leakage performance, and other data. 


\section{Data Sources and Methods}

\section{Observation}

During initial assessment of the test home, implementation of measures, and upon completion of measures, CEDA Weatherization staff collected data in the form of photos, customer interviews, and narratives. Expertly assembled and narrated videos shot during assessment of the prospective test homes proved an extraordinarily effective tool to communicate comprehensive information about the building to the BSC project team. The information conveyed in the videos allowed remote research team members to provide informed guidance concerning the measures to be implemented.

\section{Measurement}

Prior to the weatherization work and after completion of measures, CEDA Weatherization staff performed air leakage measurements on the test home. Air leakage performance was measured through the use of blower door testing. Measurements for each home were taken with the home in various configurations. For example, configurations with the door from the main living area to the basement opened and closed were included. A calculation of air flow in cubic feet per minute at an induced pressure difference of 50 Pascals, or cfm50, was derived for configurations at which measurements were taken.

The size and arrangement of the subject houses is substantially similar across the test homes evaluated in this report. Because of this, gross comparison between data can be made using the derived estimates of $\mathrm{cfm} 50$ air leakage. Relative reduction (e.g. percent reduction) in air leakage measurement is deemed to provide adequate normalization to allow comparisons within the test home sample and also with CEDA Weatherization work outside of the research project.

\section{Cost Information}

Many of the specific measures implemented in the research project are measures included in CEDA's regular weatherization program. Pricing for these measures in terms of material costs and labor inputs are established in a catalog of measures for the weatherization program. The research project used the same pricing as in the regular weatherization program for usual weatherization program measures.

Some of the measures implemented in the research project are not defined in the regular weatherization program. Prices for these measures were determined through negotiation with the contractor selected to perform the research strategy implementations. These prices were negotiated after the contractor implemented the first roof rafter insulation and air sealing approach at House 1 as part of the process to develop this approach. The pricing was not renegotiated during the period of the research project. Work orders developed by CEDA Weatherization then used the weatherization program measure pricing as well as negotiated research measure pricing to develop package costs for each test home.

\section{Limitations of Performance Measurement}

Air leakage measurements combined with energy modeling provide an estimate of energy performance impacts of the research measures. Another means to gauge the energy performance impact of the strategies implemented would involve collection of actual energy consumption data over periods of time before and after the retrofits. Given the timeframe for the research and 
measure implementation, it will not be possible to obtain post-retrofit energy consumption data reflecting heating season conditions after implementation of the research project. Monitoring of interior conditions and analysis of utility billing data is discussed in Section 9, "Recommendations for Future Work". 


\section{Retrofit Measures}

The retrofit measures that are the focus of this research project are grouped into two separate strategies for insulating and air sealing the top of the building enclosure. The first strategy involves best practice implementation of typical weatherization measures to insulate and air seal the attic floor. The second strategy establishes the thermal enclosure boundary at the roof plane by insulating and air sealing between roof rafters. The subject homes in this project also receive a group of prerequisite measures aimed at combustion safety and indoor air quality (IAQ).

Due to the conditions of the supplemental funding for the research measures (i.e. the attic and roof insulation strategies), a variety of typical weatherization measures will be implemented along with the research measures in each test home. These measures may include replacement of light bulbs, weather stripping, furnace tuning, installation of cellulose in wood-framed walls of converted porches, and insulation and air sealing of crawlspace walls. In two cases, the retrofit work also involved replacement of an older boiler and direct-fired water heater with a condensing direct-vent boiler and a storage water heater.

The strategies implemented in this research project involve the application of two-part foam sealant. While skills to apply foam sealant are relatively widespread, there does not appear to be widespread appreciation for the potential hazards - particularly occupational hazards — apparent in use of two-part foam kits. The contractor implementing the work in the research project was given procedural guidance for application of two-part foam as well as equipment to assess airborne concentrations of hazardous substances.

\section{Prerequisite Measures}

BSC provided guidelines for minimum combustion safety and indoor air quality measures to be implemented at each test home in the research project as follows:

\section{Combustion Safety}

- Atmospherically vented water heaters, boilers or furnaces, where present, must be fitted with power venting.

\section{Background Ventilation}

- A mechanical ventilation system capable of delivering ventilation rates identified in ASHRAE 62.2 must be established in each home treated.

- For homes without forced-air heating, this ventilation system will consist of a suitable bath fan (rated for continuous duty and less than 1.0 sones) and an appropriate controller.

- Homes with forced-air heating could employ central fan-integrated supply (CFIS) ventilation involving a ducted outdoor air intake, motorized damper, balancing damper and controller.

- The ventilation system should be initially commissioned at $\sim 50 \%$ of the ASHRAE 62.2 ventilation rate. Information concerning how to recognize signs that ventilation rate is too low and how to adjust the ventilation rate must be conveyed to the homeowner.

CEDA Weatherization has incorporated the combustion safety measure by including powerventing or replacement of a boiler with sealed combustion boiler in work scopes of research test 
homes. Initially, the work scopes for test homes also included installation of a bath fan with a 20minute auto shut-off timer and integrated humidity sensing control. While this bath fan represents a significant improvement relative to pre-retrofit conditions, it does not constitute a system capable of meeting the background ventilation rates given in ASHRAE 62.2.

Subsequently, CEDA Weatherization identified a suitable controller that provides for manual control and is also capable of operating the bath fan as needed to satisfy ASHRAE 62.2 background ventilation guidelines.

Prior to implementing measures to control air flow and heat flow at the top of the building, it is necessary to prioritize water control. Any deficiencies in roof structure water control need to be remediated before advanced energy performance measures can be implemented. It is especially important to repair roof leaks prior to insulation of roof rafters. Roof rafter insulation could prevent observation of roof leakage or leakage-related moisture damage. The weatherization program does allow for some patching and repair of flashing implemented in conjunction with weatherization measures. If the cost allowance for this work is not sufficient to fix the roof leaks at a particular home, the CEDA Weatherization team defers advanced thermal work at the home and instead refers the home to a roof repair program.

\section{Attic Deck Insulation Strategy}

Adding insulation to an attic floor, whether the attic floor had insulation previously or not, is a fairly widespread and typical weatherization measure. In typical weatherization activity, the addition of attic insulation may or may not be accompanied by air sealing. For example, in the regular CEDA Weatherization programs, loose-blown fiberglass insulation may be installed over existing attic insulation or cellulose may be dense-packed beneath existing attic floorboards. Neither of these typical approaches to adding insulation allow for access to critical air leakage sites concealed by attic floorboards.

Within CEDA Weatherization programs, the typical insulation target for attic floor insulation is R40. The same target was selected for this research project. An objective of the research project was to demonstrate the best performance improvement feasible for this attic insulation approach. Therefore, prior to the start of research project implementation work, BSC and designated consultants to the BSC BA research team as well as consultants to CEDA met with CEDA technical staff and contractors working in CEDA programs to identify measures necessary to achieve optimal improvement in an attic floor insulation and air sealing approach. The best practice air sealing guidelines in "Attic Air Sealing Guide and Details" (Lstiburek, February 2010) were designated as defining the air sealing work scope. BSC was also available to provide guidance on situations not addressed in the air sealing guide.

The following is an outline of measures included in the attic deck insulation strategy:

1. Remove attic floorboards if present.

2. Air seal penetrations, chases, soffits, flues, etc. as per "Attic Air Sealing Guide and Details."

3. Air seal the furring cavity at the exterior wall. 
4. Construct an insulated and gasketed moveable hatch hinged and with counterweight for walk-up stair openings, or construct insulated and gasketed cover for attic ladder-access hatches.

5. Construct a storage platform according to needs of the homeowner.

6. Install pre-formed roof vent baffles in rafter bays to block insulation from the soffit.

7. Install cellulose insulation to a uniform depth of 12 ”.

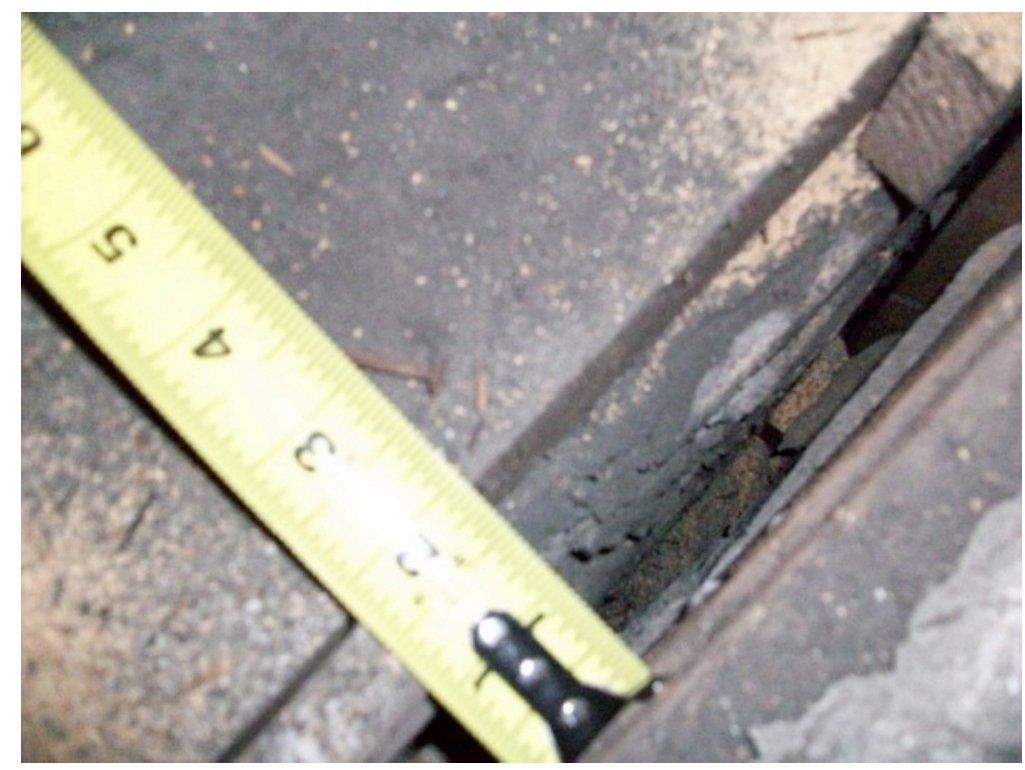

Figure 2. Furring cavity between brick masonry and interior finish as seen from the attic

Treatment of the hatch for walk-up stair access and the storage platform are measures not directly described in "Attic Air Sealing Guide and Details." For the moveable hatch over access stairs, BSC advised that the cover be constructed similar to an access hatch cover with plywood or dimensional lumber around the opening to act as an insulation dam, edge support, and a substrate for gasketing.

When an attic floor is insulated to the R40 target thermal performance level with cellulose, the depth of the cellulose will typically be significantly greater than the depth of framing. Because this will render the attic largely unusable as a storage space (in fact, when the thermal enclosure is implemented at the attic floor, frequent access to the attic space should be avoided/discouraged) it may be appropriate to provide the customer with a small storage platform in the attic. BSC provided the following guidance for storage deck construction: ${ }^{3}$

- Raise a plywood platform on braced 2x6 framing running perpendicular to attic floor framing/ceiling joists, or

\footnotetext{
${ }^{3}$ Both of these approaches to storage platform assume $\sim 5 \frac{1}{2}$ " ceiling joist depth and that the cavity beneath the storage platform will be dense packed with insulation.
} 
- Lay rigid insulation board to a thickness of 4" (XPS) or 3" (polyisocyanurate) on the ceiling joists and fasten $1 / 2$ " plywood or OSB to the ceiling joists through the insulation.

For both of these approaches:

- Install insulation dams at the sides of the platform to keep insulation off the platform and, more importantly, to mark the edge of the platform so that people don't mistakenly step off. The top of the insulation dams should be at least 4 " above the anticipated height of the insulation.

\section{Roof Rafter Insulation Strategy}

The approach for roof rafter insulation was developed in a prototype implementation (House 1). The prototype implementation followed careful assessment of conditions at the subject home and vigorous discussion of viable approaches by a team composed of BSC and CEDA technical staff as well as recognized experts in the field of building performance and weatherization. At various stages during the implementation, the air leakage control performance of the measures were assessed both qualitatively and quantitatively. Observation of the prototype implementation led to recommendations on installation and refinement of specifications.

The approach developed is an unvented roof assembly where rigid foam board insulation installed and sealed between framing provides primary air flow, vapor and thermal control. The joints between rigid foam board insulation are sealed and the board is air sealed to framing to achieve air flow control. Where the roof meets the exterior wall, the air flow, vapor, and thermal control functions are transferred to the top of the brick masonry wall using rigid foam board insulation and foam sealant. Because the brick masonry does not provide a robust air barrier function, the furring cavity between the exterior brick wall and interior wall finish (ref. Figure 2) is sealed from the attic with foam sealant.

The thermal control of the rigid foam insulation is supplemented by fibrous insulation installed to the interior of the rigid foam insulation. To achieve a nominal R-value parity with the attic deck insulation strategy, the target R-value for the roof rafter insulation assembly is R40. After review of the prototype implementation and discussion between BSC and CEDA Weatherization personnel, the roof rafter approach for subsequent test homes in the research was defined with specific roof rafter insulation assembly as follows:

1. Remove attic floorboards as necessary to allow working access to the top of the exterior wall and the top of the furring cavity at the interior side of the exterior wall.

2. Install vertical piece of $1 \frac{1 / 2}{2}$ Thermax polyisocyanurate rigid board insulation from top of wall to underside of roof sheathing. Notch rigid board insulation to fit around both ceiling and roof framing. This piece of rigid board insulation serves to 1) transition the air flow, vapor, and thermal control functions of the roof insulation assembly to the top of the brick masonry wall, and 2) separate the attic floor framing cavity from the soffit.

3. Install 3" Thermax polyisocyanurate rigid insulation board (approximately R20), in two 1/2/2" layers with joints between boards in successive layers offset by at least 8 ". Install insulation board between rafters and in contact with roof sheathing. If friction fit does not provide firm support, temporarily secure insulation board with a toenail fastening to framing. Butt seams 
in the first layer (against the roof deck) should be air sealed with either a flexible exterior grade caulk or metal tape.

4. Seal insulation board to surrounding framing, seal joints between boards, and seal any penetrations through insulation boards with two-part closed-cell spray-applied foam sealant following safe application protocol.

5. Seal the furring cavity gap between the masonry wall and interior wall finish (ref. Figure 2) with two-part foam sealant.

6. Sister lumber onto bottom cord of rafter framing as needed to provide $5 \frac{1}{2}$ " cavity depth to inside of rigid board insulation.

7. Install high-density R21 fiberglass batt or R23 mineral fiber batt insulation in extended roof framing cavities.

8. Attach Dow Weathermate or Weathermate Plus house wrap to sistered lumber to provide a continuous covering over the fibrous insulation.
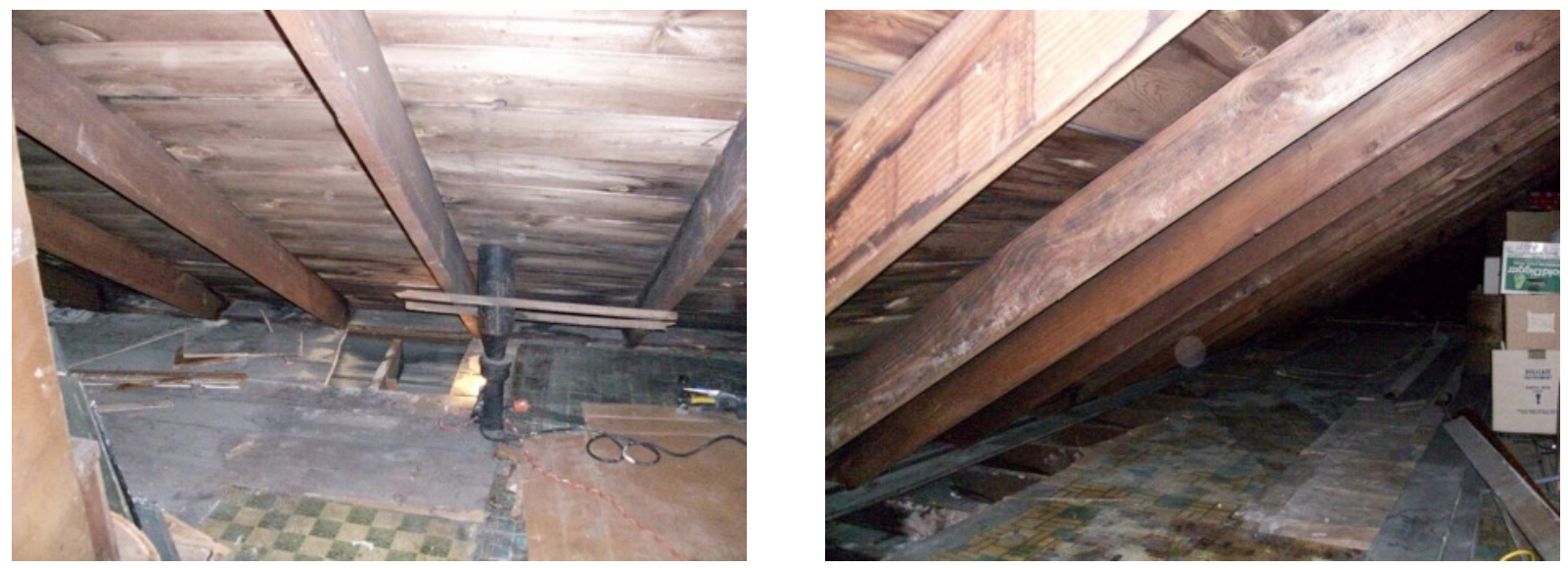

Figure 3. Left: Attic floorboards removed to investigate conditions at top of wall during assessment of prototype house; Right: Attic floorboards removed to allow access to top of wall 


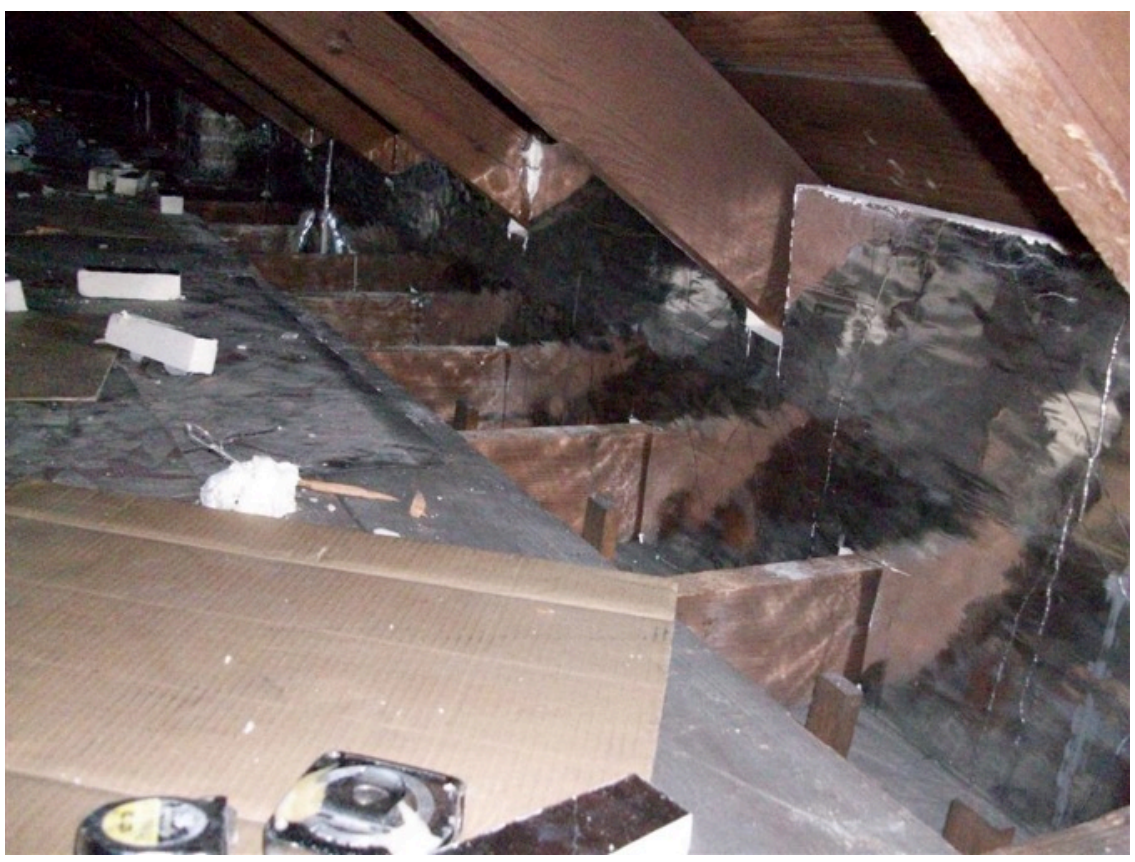

Figure 4. Foil-faced polyisocyanurate board insulation installed to transition thermal control from top of masonry wall to roof. The rigid insulation board rests on top of a wood plate at the top of the brick wall. Note that furring cavity gap (at junction of wall plaster and ceiling plaster) is to interior side of the rigid board insulation as indicated by wood furring extending above the top of the brick wall.

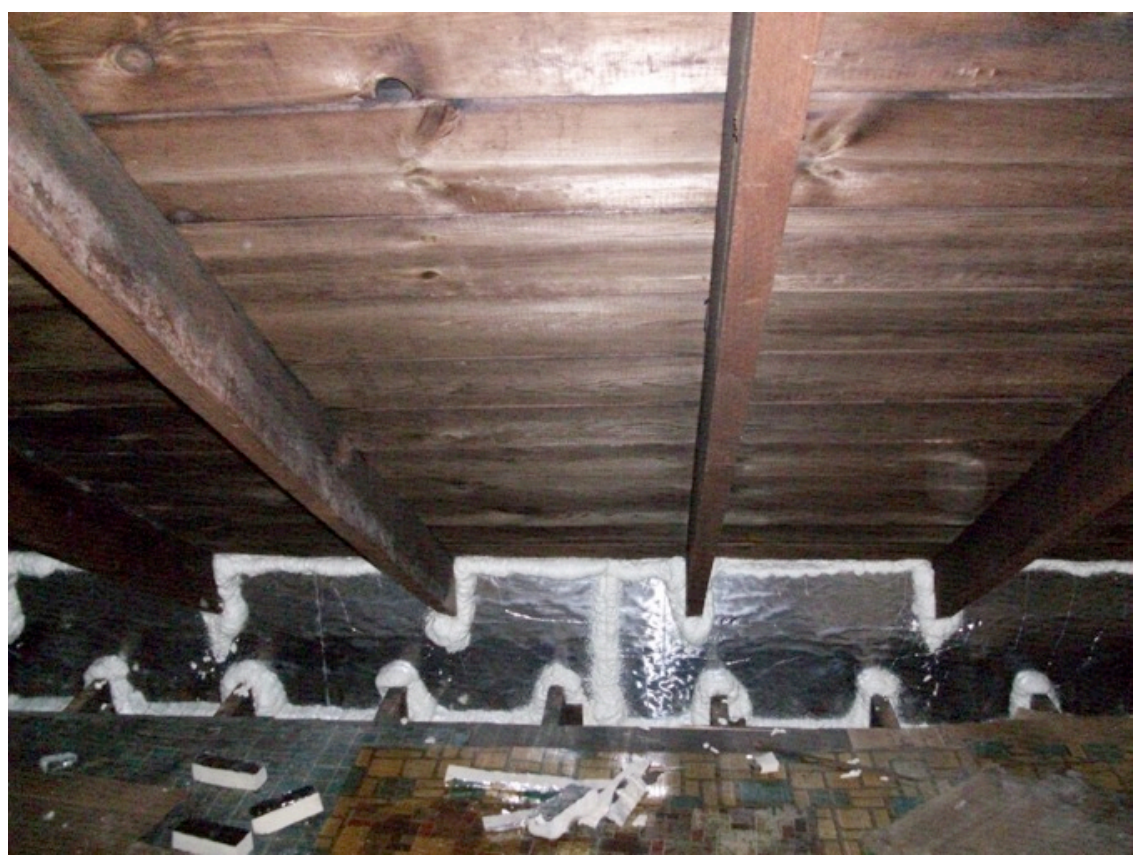

Figure 5. Foil-faced polyisocyanurate insulation board with seams and joints sealed to adjacent framing 


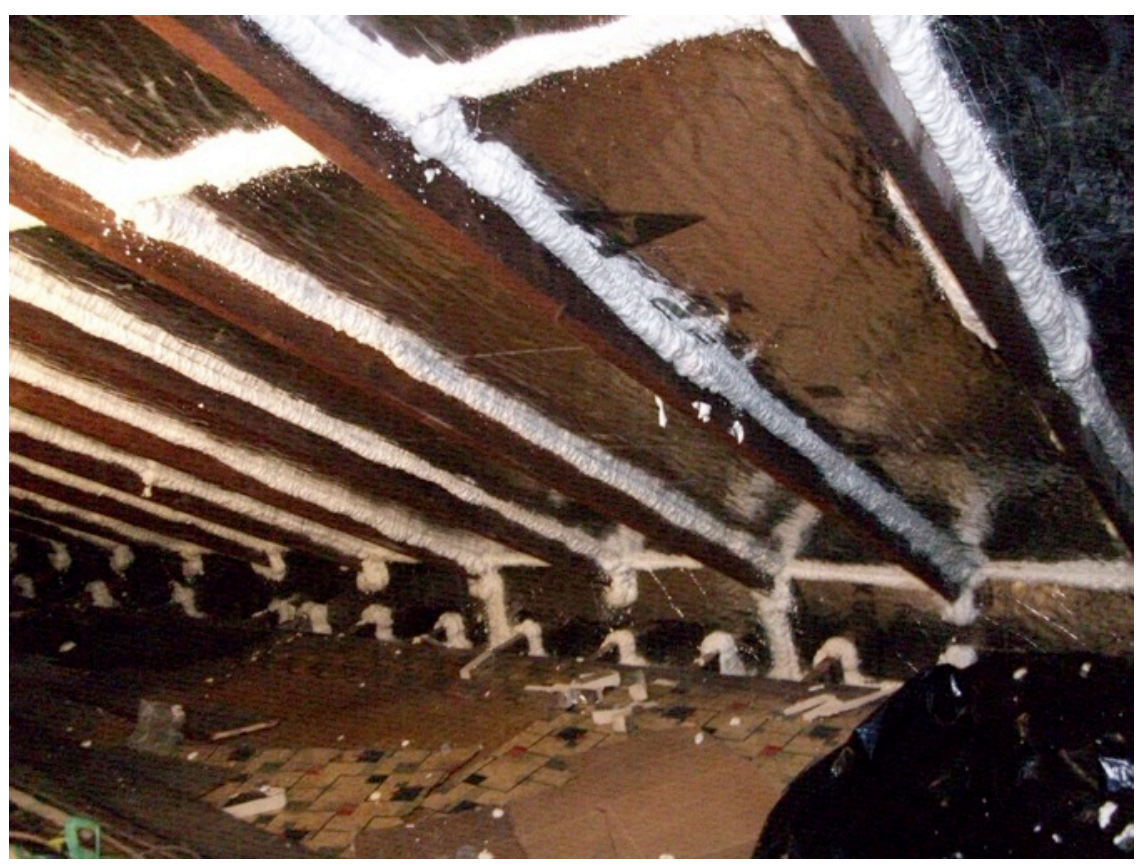

Figure 6. Foil-faced polyisocyanurate insulation board between roof rafters and transitioning to top of wall with seams and joints to adjacent framing sealed

The attic dormers, characteristic to the Chicago brick bungalow, present vertical walls with framing cavities that are usually more shallow than the framing cavity between roof rafters. Where the framing cavities are accessible, the open framing cavities are insulated and air sealed as the roof cavities. Where interior finishes prevent access to the framing cavities, the vertical dormer walls are dense-packed with cellulose insulation.

To allow the contractor flexibility to respond to conditions of the test homes and material prices, BSC provided the following guidelines for variations to the basic roof rafter specifications:

\section{Cellulose fibrous insulation alternate:}

- Sister/extend the roof rafters to provide a cavity of sufficient depth to accommodate cellulose installation achieving R20.

- Secure house wrap to the roof rafter extensions with cap nails or battens.

XPS rigid foam board insulation alternate:

- Install 2" XPS rigid insulation board between rafters and in contact with the roof sheathing, followed by $1 \frac{1 / 2}{2}$ Thermax polyisocyanurate rigid insulation board installed between rafters and in contact with the XPS insulation board. 


\section{Deciding Factors}

A desired outcome of the research was to successfully implement multiple examples for each top-of-building strategy. Objectives of the research are subordinate to the obligation to provide a benefit to homeowners. For each candidate test home, decisions about which strategy to employ are based upon careful consideration of building conditions and use. While the decision was informed by many factors, the factors discussed below are noted as significant and recurring. The applicability of these factors to the test homes are summarized in Table 1 below.

\section{Finished or Used Space}

A common feature in the Chicago bungalow is walk-up access (stairs) to the attic. It is not uncommon for the attic to be or to contain finished and heated space, semi-finished space, bedrooms, or occasional-use rooms. It is also not uncommon to find heating distribution extended to the attic. Rendering a space in use unusable, even if also reducing the home's total energy use, would be tantamount to taking a valuable resource away from the customer. Therefore, the roof rafter insulation and air sealing approach is favored if the attic space contains semi-finished space or exhibits significant use. However, it should be noted that finishes attached to the underside of rafters or otherwise obstructing access to framing cavities complicates implementation of the roof rafter approach.

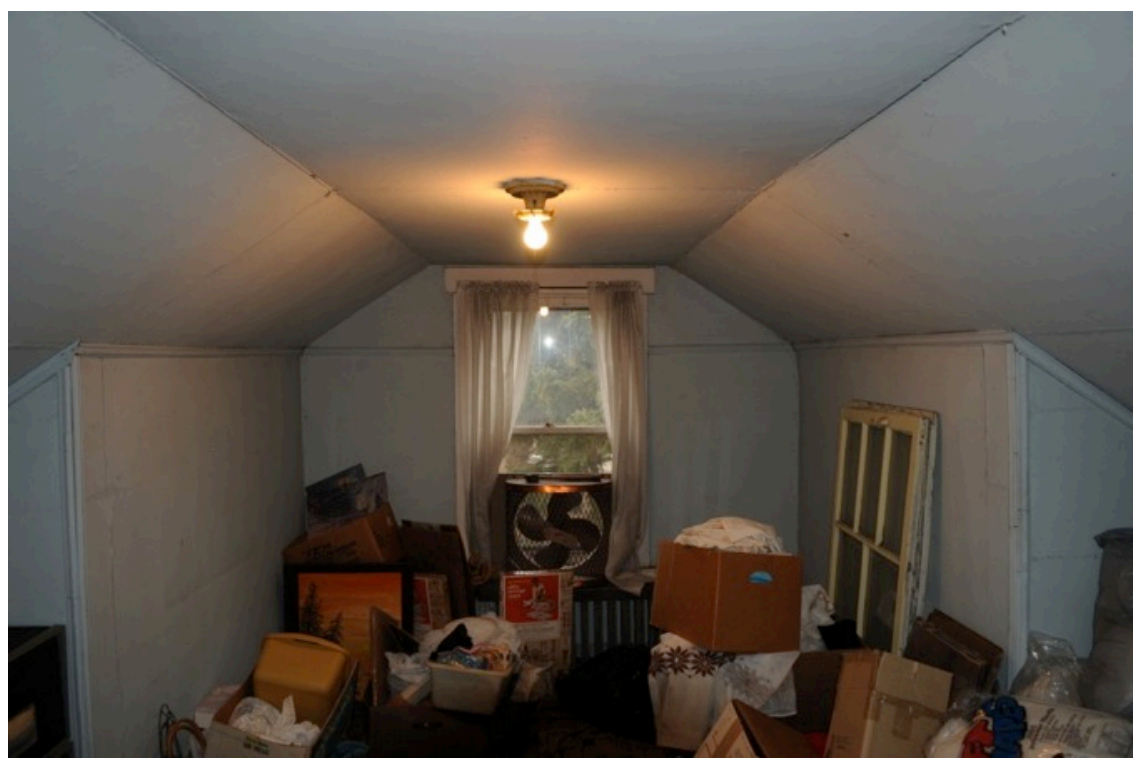

Figure 7. Finished room in attic of House 1 (Photo credit: E. Haber, printed with permission)

The residents of test homes that were designated for the attic floor approach indicated little or no use of the attic space. Factors coincident with low use of the attic include constrained access, such as a ladder-access attic hatch, or health/age of residents that makes use of even a walk-up attic difficult.

\section{Access for Air Sealing at Attic Floor}

The type of building that is the subject of this research typically exhibits significant connections between the attic space and basement through chases and furring cavities. Air leakage sites 
connecting the attic to the living space such as soffits over bathroom and kitchen areas, interior plumbing walls, and chases around chimneys are also prevalent. Access to the topside of the ceiling surface is needed to establish effective air flow control at the attic floor. Attic flooring and finishes that complicate access to critical air leakage bypasses are factors favoring implementing the roof rafter insulation and air sealing approach.

The test homes that were designated for attic floor insulation and air sealing in this project all had easily removable attic floorboards or no attic floorboards.

\section{Feasibility of Air Sealing and Insulation at Attic Access}

Walk-up attic stairs are a common feature in Chicago bungalow-style homes that can make it difficult to achieve effective air sealing and insulation at the separation between the attic and first floor. Given the complicated geometry and surface area of the stair enclosure, the most realistic location for a thermal control is over the top of the stairs in plane with the attic floor. Stairs with switch-back runs or those that would otherwise present challenges to creating an effective and serviceable attic access cover would favor implementation of the roof rafter insulation and air sealing approach. Conversely, straight run stairs, pull-down stairs, and scuttle hatches present less impediment to the attic deck insulation and air sealing approach.

\section{Storage}

Storage of resident belongings is typical in structures where attics are more accessible. A large amount of belongings in an attic complicates any strategy for insulating and air sealing the top of the building. This might require moving belongings multiple times, and may also require that air sealing and insulation at the attic floor be completed in multiple stages. Therefore, a large amount of stored items might affect the attic floor approach more than the roof rafter approach.

Storage space represents a benefit for the homeowner. Taking away storage space may negatively affect the overall impression of the weatherization work. The more an attic is used for storage, the more likely that loss of storage will be perceived as negating benefits to residents of weatherization activities. 
Table 1. Summary of Common Decision Factors at Test Homes

\begin{tabular}{|c|c|c|c|c|c|}
\hline $\begin{array}{c}\text { Test } \\
\text { Home }\end{array}$ & $\begin{array}{l}\text { Strategy } \\
\text { Design- } \\
\text { ated }\end{array}$ & $\begin{array}{c}\text { Finished } \\
\text { Space/Use in } \\
\text { Attic }\end{array}$ & Attic Floor & Attic Access & Storage \\
\hline House 1 & $\begin{array}{l}\text { Roof } \\
\text { Rafter }\end{array}$ & $\begin{array}{l}\text { Semi finished } \\
\text { craft room at } \\
\text { one end of attic, } \\
\text { disconnected } \\
\text { radiator }\end{array}$ & $\begin{array}{l}\text { Tongue and } \\
\text { groove (T\&G) } \\
\text { floorboards, } \\
\text { sheet good } \\
\text { floor cover }\end{array}$ & $\begin{array}{c}\text { Switch back } \\
\text { stair }\end{array}$ & heavy \\
\hline House 2 & $\begin{array}{l}\text { Attic } \\
\text { Deck }\end{array}$ & none & none & Scuttle hatch & none \\
\hline House $3 *$ & $\begin{array}{l}\text { Roof } \\
\text { Rafter }\end{array}$ & $\begin{array}{l}\text { Carpet at sorting } \\
\text { or craft platform }\end{array}$ & floorboards & $\begin{array}{l}\text { Switch back } \\
\text { stair }\end{array}$ & heavy \\
\hline House 4 & $\begin{array}{l}\text { Attic } \\
\text { Deck }\end{array}$ & none recent & $\begin{array}{c}\text { loose } \\
\text { floorboards }\end{array}$ & $\begin{array}{l}\text { Straight run } \\
\text { stair }\end{array}$ & light \\
\hline House 5 & $\begin{array}{l}\text { Roof } \\
\text { Rafter }\end{array}$ & $\begin{array}{l}\text { Loose carpet on } \\
\text { floor }\end{array}$ & floorboard & $\begin{array}{c}\text { Switch back } \\
\text { stair }\end{array}$ & none \\
\hline House 6 & $\begin{array}{l}\text { Attic } \\
\text { Deck }\end{array}$ & none & $\begin{array}{c}\mathrm{T} \& \mathrm{G} \\
\text { floorboards }\end{array}$ & $\begin{array}{l}\text { Switch back } \\
\text { winder stair }\end{array}$ & none \\
\hline House 7 & $\begin{array}{l}\text { Roof } \\
\text { Rafter }\end{array}$ & Active storage & floorboards & $\begin{array}{l}\text { Straight run } \\
\text { stair }\end{array}$ & moderate \\
\hline House 8 & $\begin{array}{l}\text { Roof } \\
\text { Rafter }\end{array}$ & None apparent & floorboards & $\begin{array}{l}\text { Switch back } \\
\text { winder stair }\end{array}$ & light \\
\hline House 9 & $\begin{array}{l}\text { Attic } \\
\text { Deck }\end{array}$ & Active storage & floorboards & $\begin{array}{l}\text { Straight run } \\
\text { stair }\end{array}$ & moderate \\
\hline House 10 & $\begin{array}{l}\text { Attic } \\
\text { Deck }\end{array}$ & Active storage & floorboards & $\begin{array}{l}\text { Straight run } \\
\text { stair }\end{array}$ & moderate \\
\hline House 11 & $\begin{array}{l}\text { Roof } \\
\text { Rafter }\end{array}$ & $\begin{array}{l}\text { Active storage, } \\
\text { semi-finished } \\
\text { room in poor } \\
\text { condition }\end{array}$ & floorboards & $\begin{array}{l}\text { Straight run } \\
\text { stair }\end{array}$ & moderate \\
\hline
\end{tabular}

House 3 is listed in this table although no measures were implemented in this test home. CEDA Weatherization technical staff conducted a thorough assessment and the implications for attic deck and roof rafter strategy were discussed among the research team. After designation of the insulation and air sealing strategy and preparation of a work scope, House 3 was deferred due to structural concerns. The numbering convention was maintained since assessment work had already proceeded on most of the homes, and renaming files would have risked confusion. 


\section{Implementation Assessment}

\section{Implementation Observations}

\subsubsection{Attic Deck Insulation}

At the time of this report, the attic deck insulation and air sealing approach has been

implemented through this research effort in three designated test homes. Implementation in two more homes is expected by early 2012 .

\section{Remove attic floor boards}

Removal of attic floorboards is not typically conducted in weatherization activity. The crews implementing this work improved techniques to remove floorboards during the course of the project. They learned that clean-up was easier and more material could be repurposed if boards are removed largely intact.
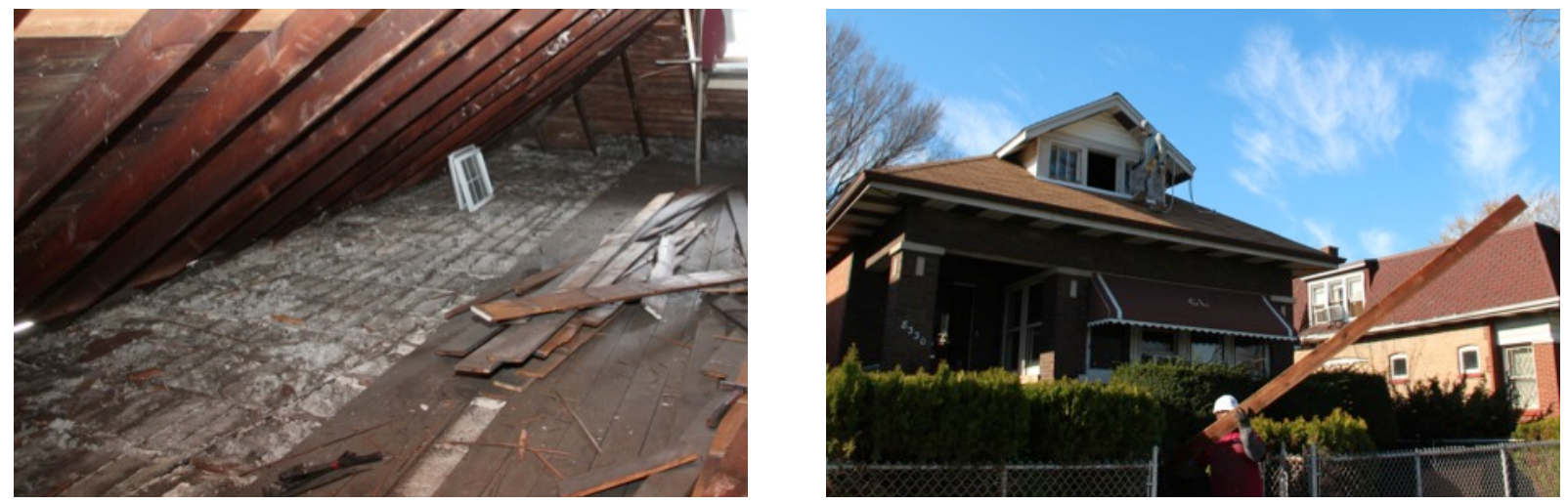

Figure 8. Left: Attic floorboards partially removed for attic deck air sealing and insulation; Right: Attic floorboards removed intact (Photo credit: S. Marchese, printed with permission)

\section{Air seal penetrations, chases, soffits, flues, and bypasses}

Observations showed that air sealing with one- or two-component foam is a familiar process for the contractor. The extent of air sealing and some of the specific measures in the work scope appeared to be less familiar. With the presence of existing insulation material or other debris, much work is often needed to provide a suitable substrate for air sealing materials.
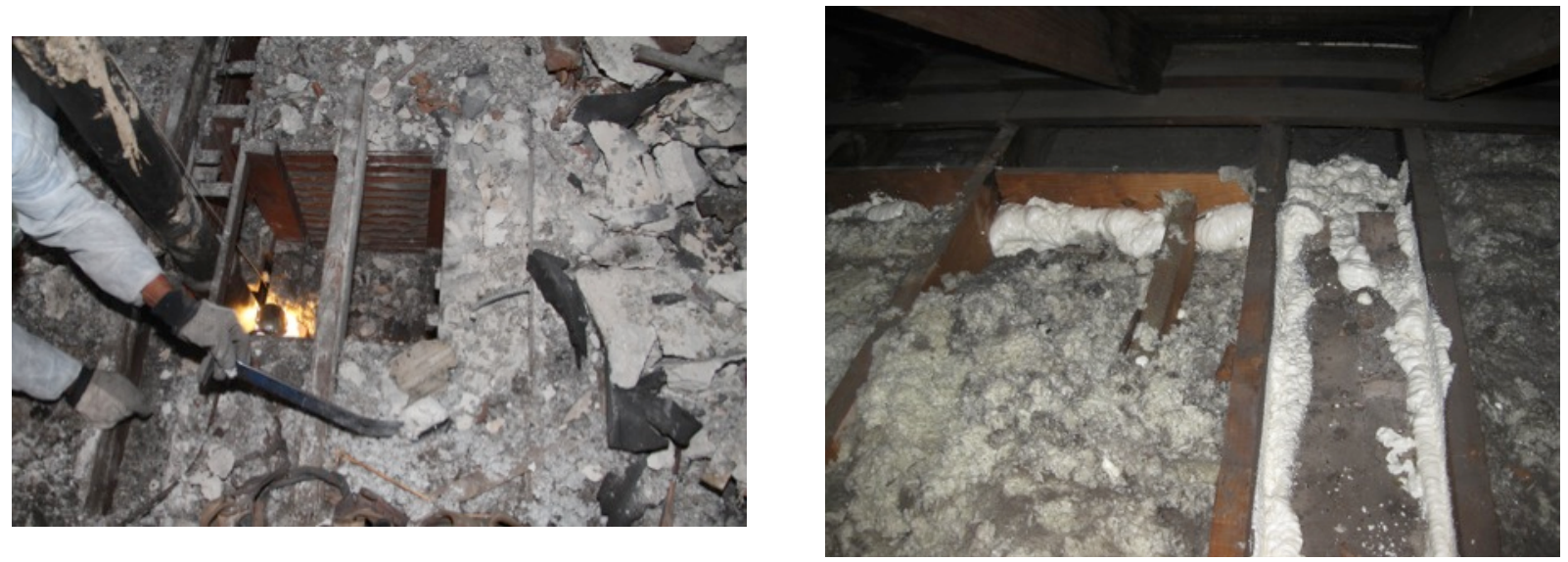

Figure 9. Left: Creating access to dropped soffit area and plumbing wall; Right: Attic floorboard repurposed in sealing plumbing chase (Photo credit: S. Marchese, printed with permission) 
Some details involving treatment of bath fan enclosures and electric junction boxes were not consistently executed as indicated in "Attic Air Sealing Guide and Details." It seems that the contractor favored two-part foam over tape and caulk because of the speed and versatility of the two-part foam application. The contractor also relayed that constructing boxes over recessed lights, for example, using taped gypsum board as indicated in the referenced guide was not practical at the prices paid for these measures in the regular weatherization program. In the case of the electrical junction box, it is conceivable that the budget for the work at the test home would not support electrical work that would have permitted treating the junction box as indicated in this guide (Figure 11).

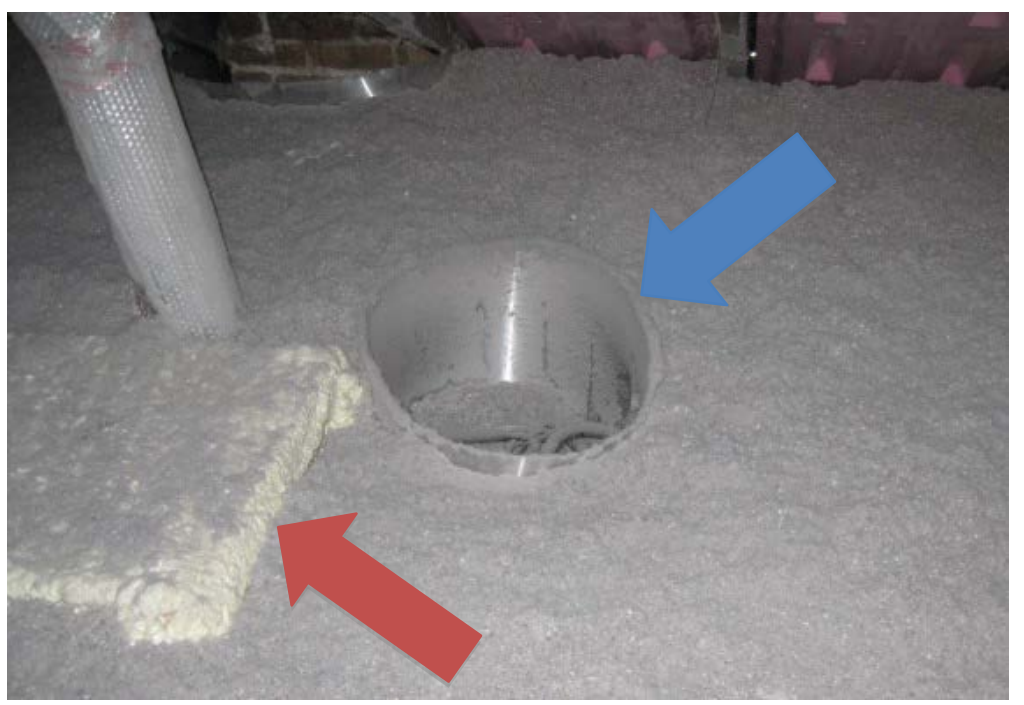

Figure 10. Bath fan housing cover encased in foam sealant (red arrow) and electrical junction box surrounded by metal insulation dam (blue arrow) 

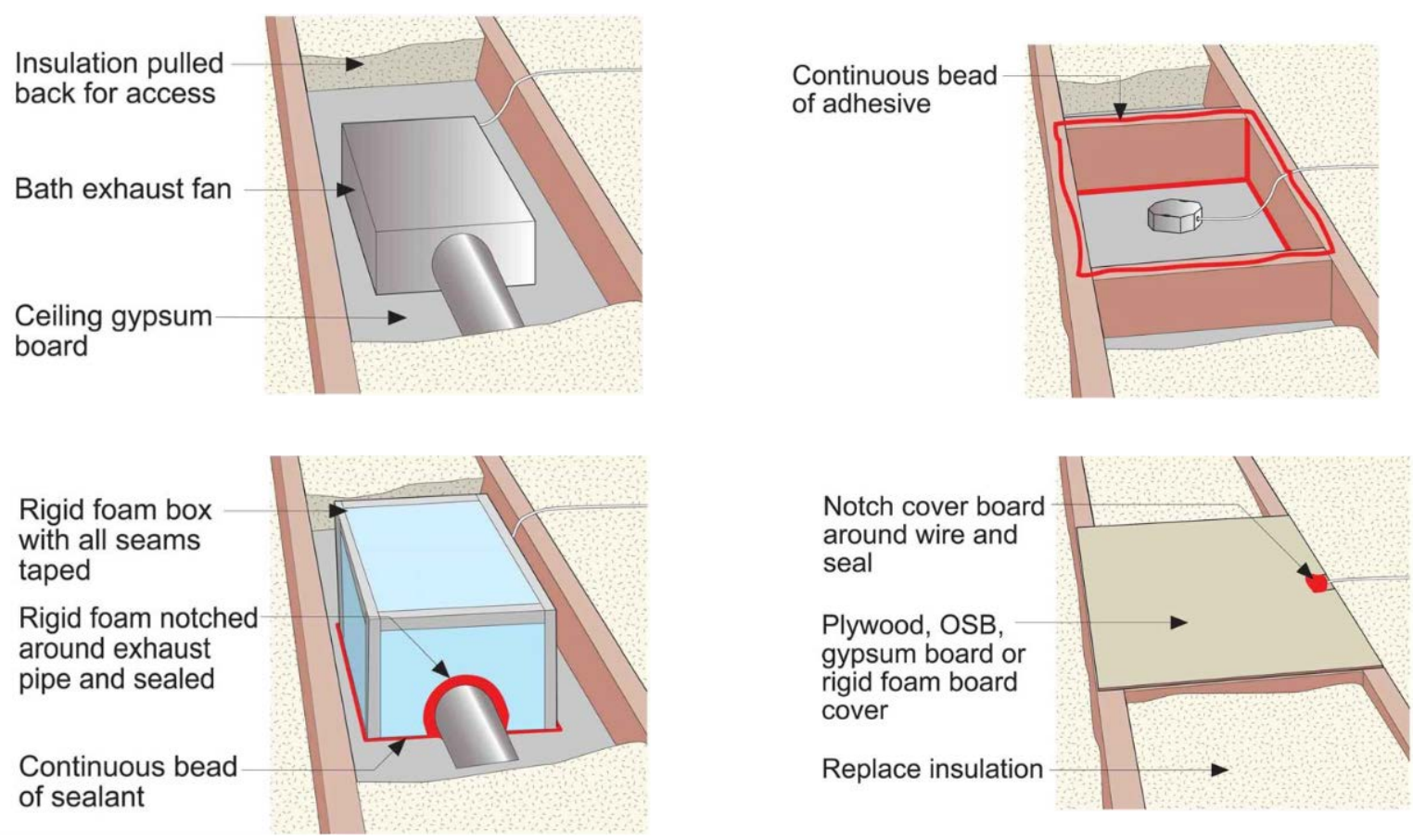

Figure 11: Left: Images from "Attic Air Sealing Guide and Details" showing steps for treatment of exhaust fan housing; Right: Images from this guide showing steps for treatment of electric junction box

CEDA Weatherization noted that a critical parameter of the effectiveness of this air sealing measure is the ability to conduct quality control assessment prior to installation of the cellulose insulation. In the research project implementations of the attic deck strategy, CEDA Weatherization assessors employed mechanical pressurization/depressurization and smoke sticks to verify effective air sealing. In CEDA's regular weatherization activity, there are not sufficient resources to provide separate in-process assessment visits. Also, contractors typically implement both air sealing and insulation in a time frame that would not allow for testing and assessment of the work.

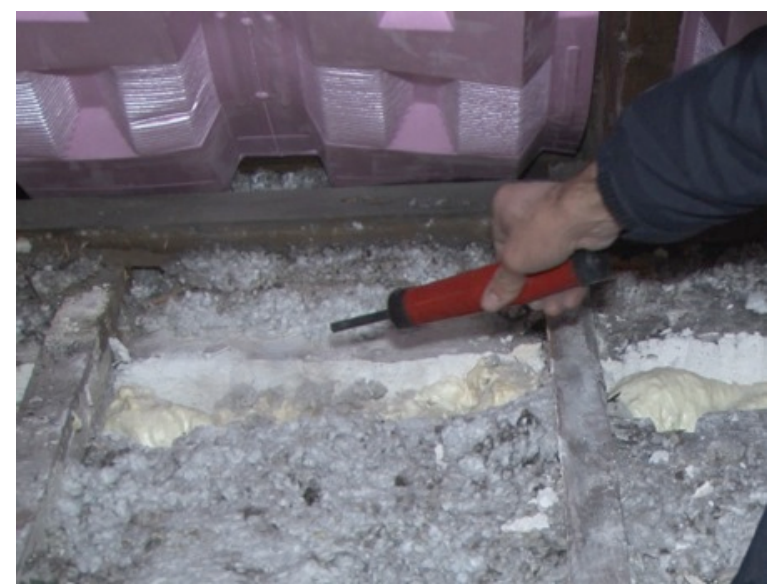

Figure 12. CEDA Weatherization assessing effectiveness of air seal at furring cavity between brick masonry and interior finish (Photo credit: S. Marchese, printed with permission) 


\section{Air seal the furring cavity at the exterior wall}

The contractor was able to successfully expose and seal the gap between the exterior wall plaster and the brick bearing wall. This required understanding the location of the thermal boundary. The inset entries and unconditioned porches mean that the exterior wall is not always aligned with the perimeter of the attic.

\section{Attic access covers}

In the three instances of the attic deck insulation and air sealing approach, the contractor encountered a scuttle hatch access, a straight run stair, and a switch-back stair. The attic access covers appear to be constructed well and included ample insulation.

A CEDA Weatherization quality control inspection found more air leakage than allowable at one instance where a scuttle hatch cover was installed without gaskets. The weather stripping typically used at these locations is an inexpensive self-adhered type. CEDA assessors have noted that this weather stripping sometimes fails during implementation of the measure. It is possible that gaskets of such weather stripping material had been installed but had since failed. Subsequent to noting the leaky attic hatch cover, the specification indicated vinyl bulb door weather stripping that is fastened with screws and sealed to the substrate with caulking.
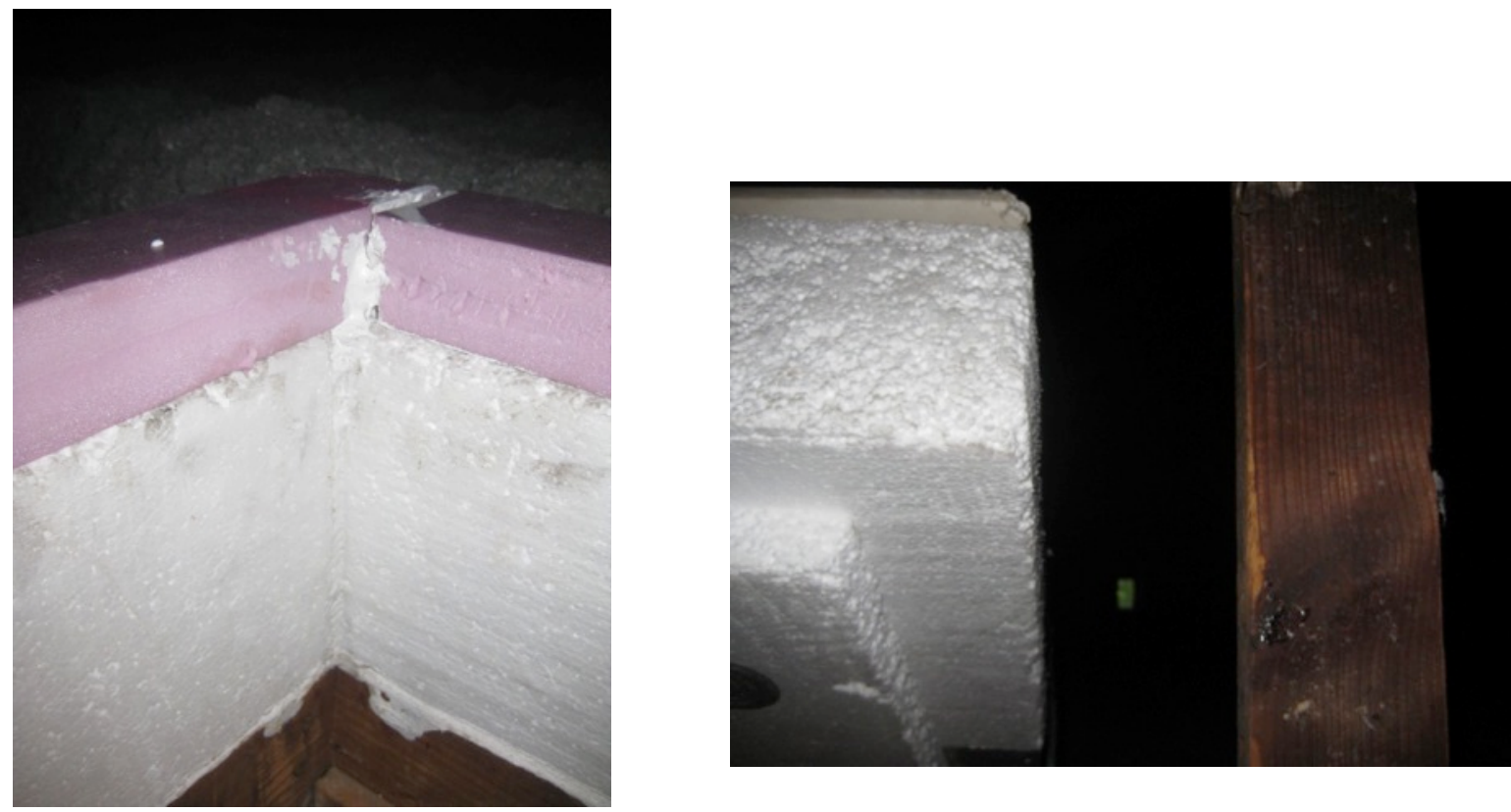

Figure 13. Left: Corner of attic access hatch insulation dam and frame; Right: Attic hatch insulated but without gaskets

The contractor provided a counterweight system for the attic stair access covers in order to facilitate operation by residents. The stair covers are also hinged to maintain the alignment of the cover and the gasketed frame. 


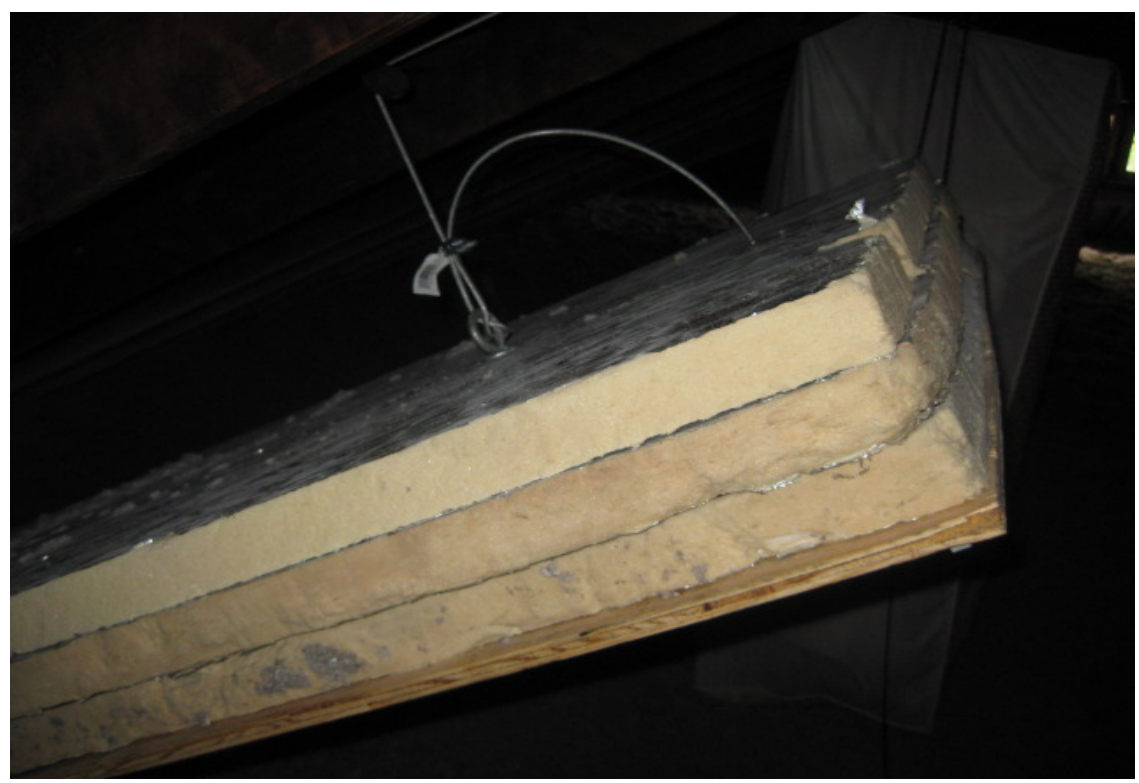

Figure 14. Hinged attic hatch with counterweight over attic access stairs. Gaskets and weather stripping are located on the stationary frame.

The contractors performing work in the test homes have shown aptitude in constructing thoroughly insulated and functional covers for attic access stairs. CEDA assessors report that these function very well. However, more widespread implementation is likely to reveal difficulties in treating stairs with switch-back runs or winding stair tread configurations.

\section{Storage Platform}

A storage platform was provided in the test homes receiving the attic deck insulation and air sealing approach. The platform is relatively small at the home with the scuttle hatch access. At the two homes with stair access to the attic, the platform provided functional storage space with a plywood walking surface and sturdy insulation dams at the perimeter of the platform. The platform was raised to provide adequate depth of insulation beneath.

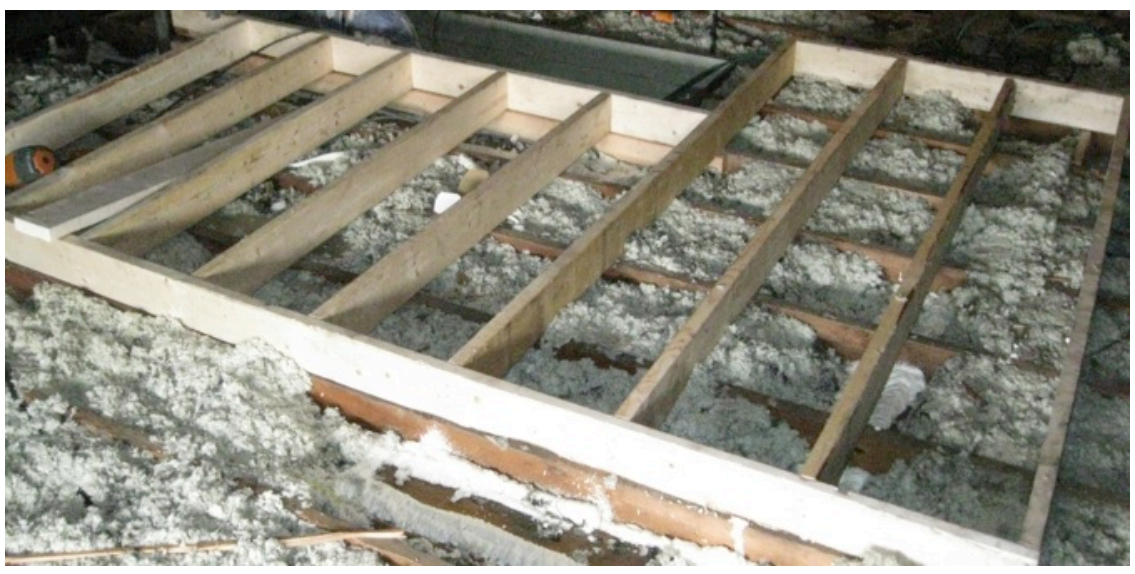

Figure 15. Storage platform framing (Photo credit: S. Marchese, printed with permission) 

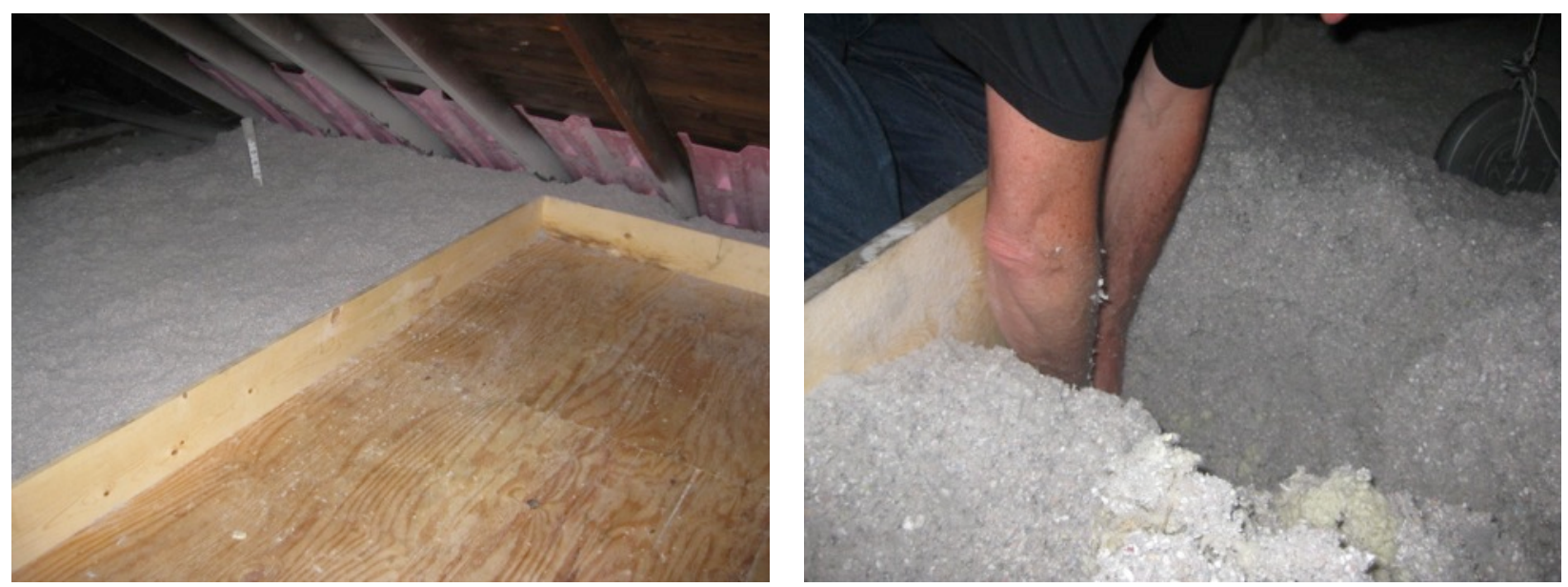

Figure 16. Left: Attic storage platform with insulation dams at the perimeter; Right: A CEDA Weatherization team member checks the depth of insulation beneath platform

\section{Roof vent baffles/insulation dams}

The non-standard and sometimes irregular spacing of roof rafters meant that the contractor had to cut pre-formed baffles to fit and/or use multiple pre-formed baffles in each framing bay. This created some additional labor and material costs relative to configurations where pre-formed vent baffles neatly fit the rafter spacing.

Pre-formed vent chutes were used primarily for blocking the cellulose from filling the roof soffit (Figure 17). The homes in this research project lacked deliberate soffit venting. The vent chutes would preserve some ventilation function for soffit vents should these be added in the future. 


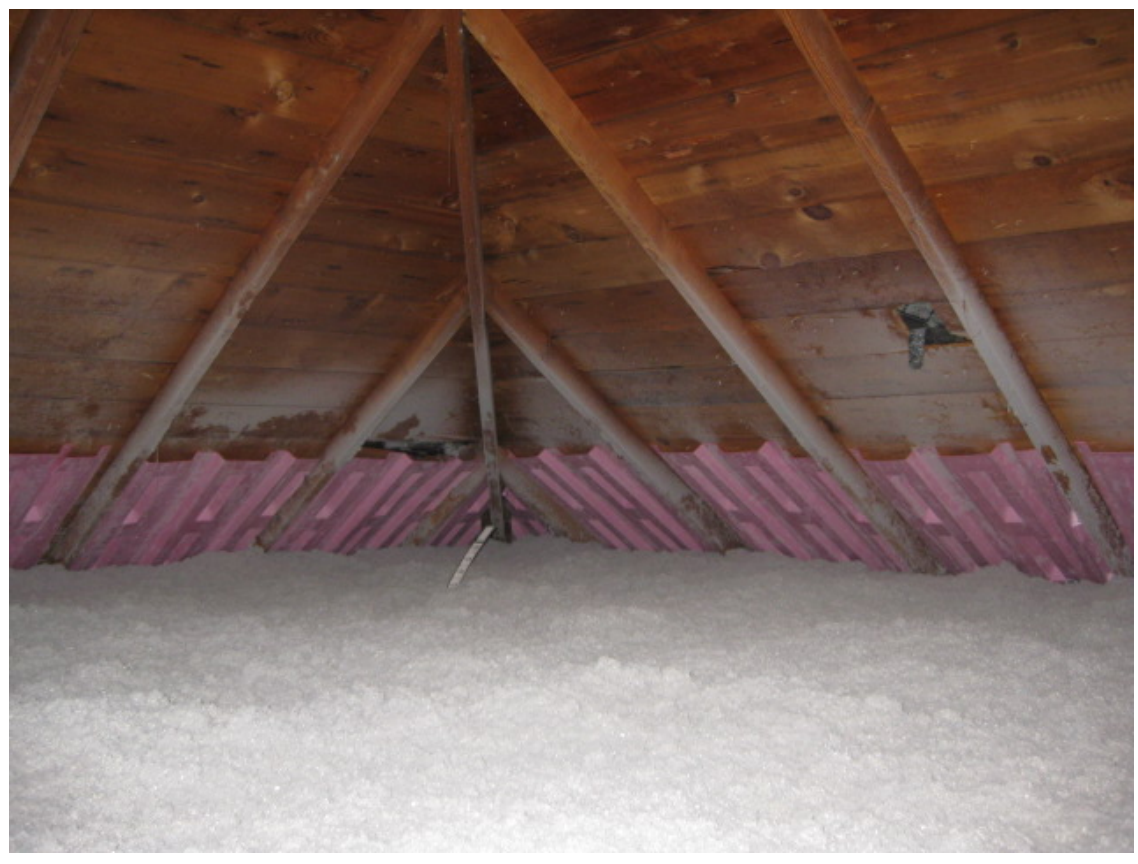

Figure 17. Vent chutes used to block cellulose from filling roof soffit

\section{Installation of cellulose insulation at attic floor}

The contractor appeared to achieve adequate and uniform insulation depth at the test homes where the attic floor was insulated to a nominal R40. In an effort to use material efficiently, the contractor employed markers to denote the line of the thermal boundary on the attic floor to guide installation. Areas of the attic overhanging unconditioned spaces could then be left uninsulated.

The experience of these three test homes confirms that blown-in cellulose insulation is a retrofit technique that can be reliably implemented to specifications. However, the full thermal performance and durable energy savings of this measure rely upon implementation of the other measures associated with this attic deck strategy.

\subsubsection{Roof Rafter Insulation}

This strategy was developed and first implemented in a prototype implementation (House 1). The contractor was not necessarily familiar with this specific process but the strategy does use skills already developed for minor demolition, cutting rigid insulation board, and air sealing. In fact, the strategy could likely be implemented by a reasonably able homeowner. The contractor also developed techniques to better facilitate the work in the course of the roof rafter insulation work. For example, the contractor learned that a sharpened drywall tapping knife is an effective tool to cut foil-faced polyisocyanurate boards.

It is evident that the roof insulation and air sealing measures were feasible with the labor and skill available to the contractor. Materials needed for the project were readily available. One significant cost factor that has emerged is that fire-rated rigid foam insulation bears a significant cost premium in the local market. 


\section{Remove attic floorboards as necessary}

Removal of attic floorboards was required in the roof rafter approach. Because air sealing the chases and bypasses between the attic and first floor is not necessary with this approach, most of the attic floorboards can remain in place. In fact, given that the approach is intended to preserve usability of the attic, it is desirable to limit removal of attic floor to those areas where removal is needed to achieve critical thermal and air flow control transitions.

With the majority of flooring remaining in place, somewhat more attention is needed to locate and expose the top of the exterior wall. At the test homes in this research project, the contractor was consistently able to correctly locate, expose, and seal the gap between the exterior wall plaster and the brick bearing wall. By taking time to review the work scope with the implementing contractor and then providing on-site guidance, CEDA Weatherization likely aided in the success of this measure.
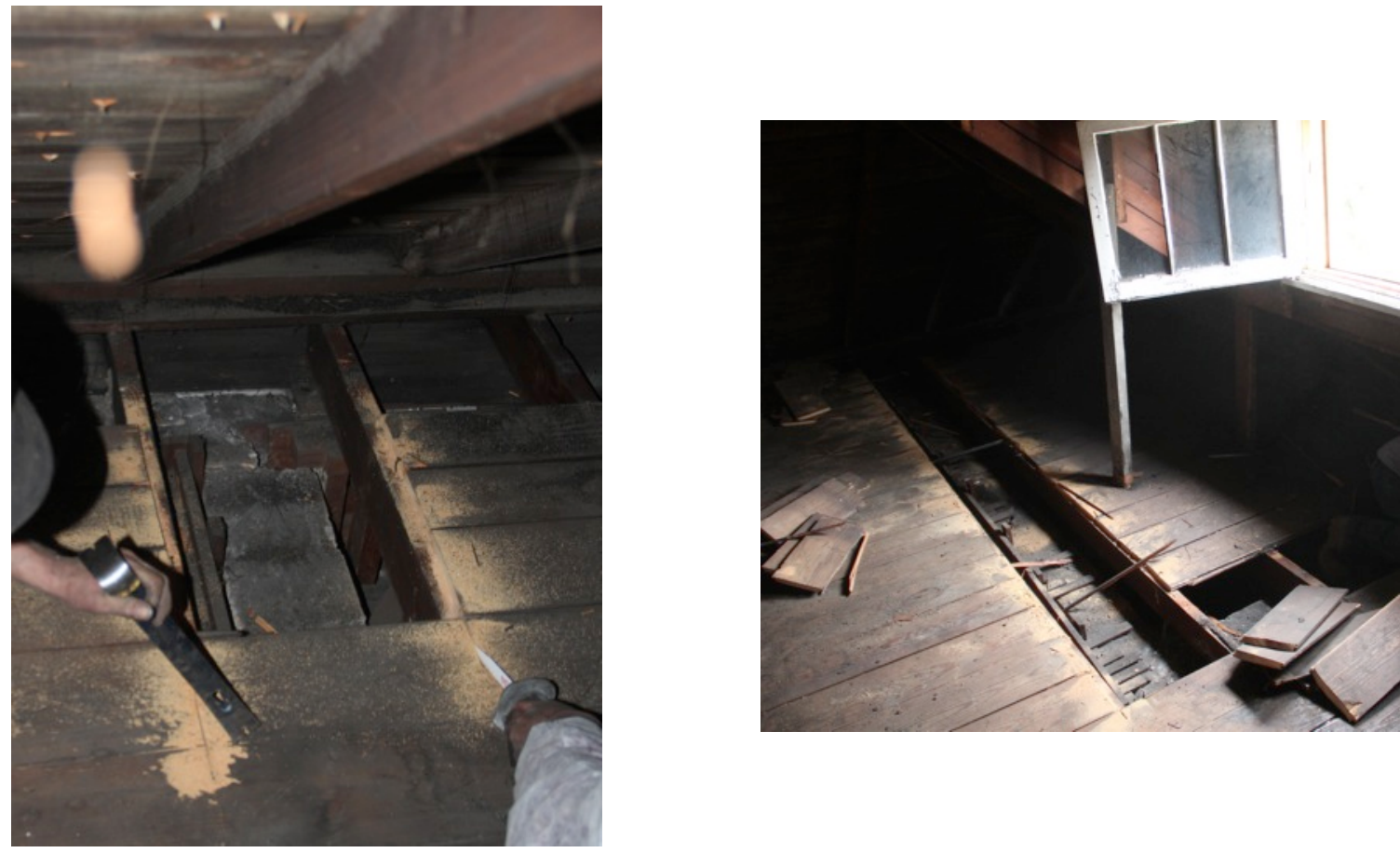

Figure 18. Left: Workers cutting access to expose top of exterior wall and furring cavity; Right: Access cut to expose top of exterior wall and furring cavity at inset opening (Photo credit: $S$. Marchese, printed with permission)

\section{Rigid insulation transition piece from top of wall to underside of roof sheathing}

The transition of air flow and thermal control from roof to wall appears to have been well implemented with notching at the bottom edge to accommodate ceiling joists and at the top to accommodate the roof framing (Figure 19). 


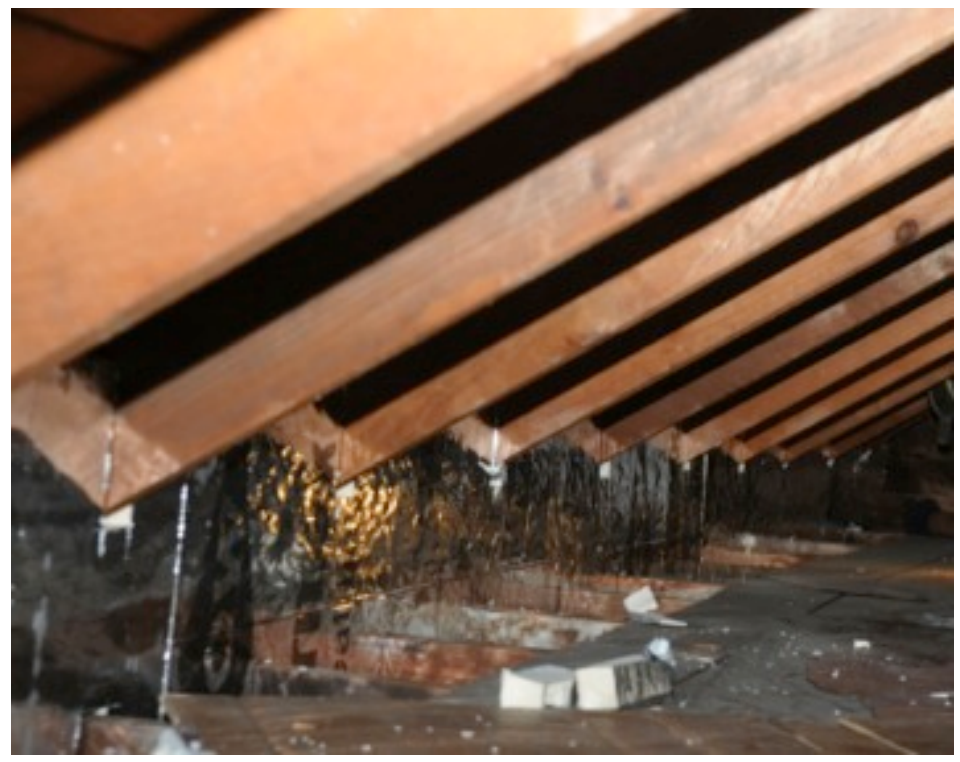

Figure 19. Foil-faced polyisocyanurate insulation notched around roof and ceiling framing (Photo credit: E. Haber, printed with permission)

The rigid board insulation transition followed the line of the exterior wall (the thermal enclosure boundary) at the floor below. Where the roof and attic project beyond the first floor thermal enclosure, such as at inset entries and unconditioned porches, the contractor constructed a framed wall to support the rigid board insulation transition (Figure 20). Initially, this step had been implemented as one of the first measures of the approach. Through multiple iterations of the roof rafter approach, the contractor learned that installing this transition after adding insulation in rafters saved both time and material.
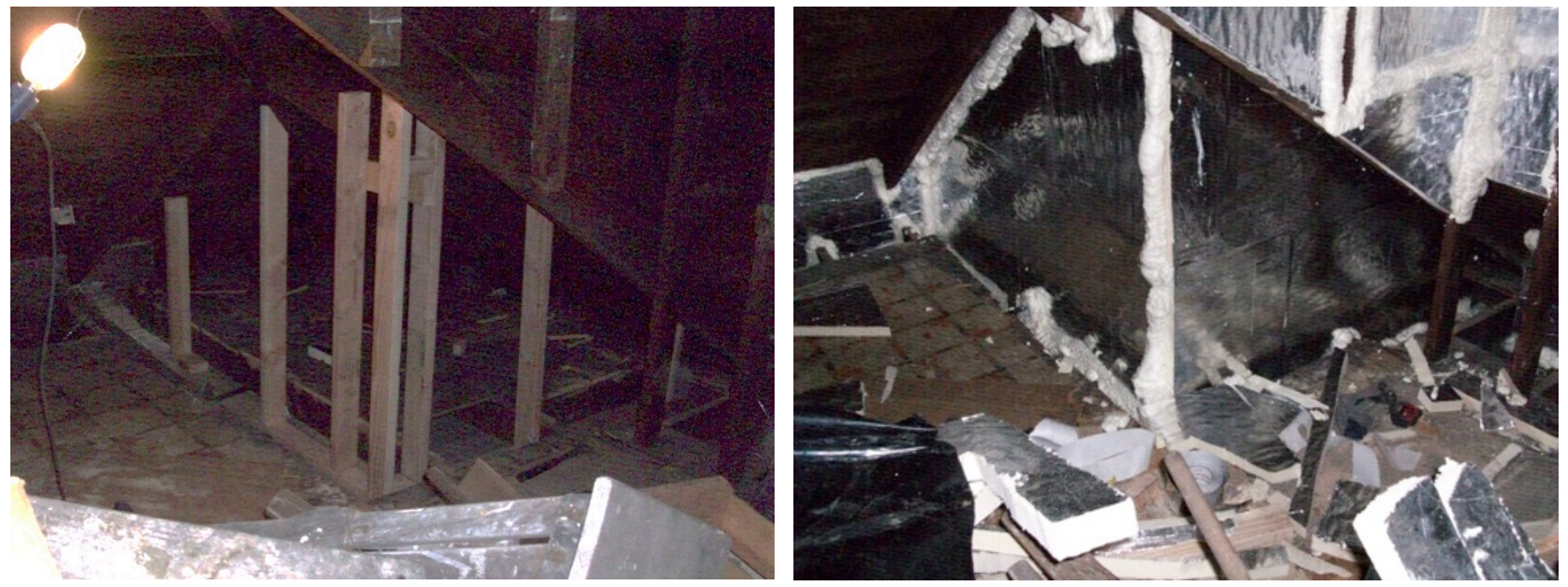

Figure 20. Left: Framing added above exterior wall at inset entry; Right: rigid board insulation installed to transition thermal control from exterior wall to roof assembly

In the prototype implementation of the roof rafter approach, the attic contained a small finished room. This room had interior finish attached to the underside of the roof rafters, and interior finish on the side walls and face wall of the dormer that was to be retained. The cathedralized 
ceiling and configuration of the face of the dormer presented challenges to some of the measures of the roof rafter approach.

The dormer face wall is located approximately 18 " to the inside of the exterior wall. This creates a small triangular space bounded by the roof, attic floor, and dormer face wall (ref. Figure 23). It was not possible for personnel to enter and work in this cavity, nor was it possible to maneuver sheets of rigid board insulation into this area. The contractor accessed this space by removing a section of interior finish at the base of the dormer face wall. Attic floor boards were then removed in small pieces to allow an attempt at air sealing the joist cavities from the porch roof soffit beyond. Cellulose was then dense-packed into the wall framing cavities and the small triangular space.

To insulate these portions of the roof, the contractor removed the small flat ceiling in the finished room and slid pieces of rigid insulation into the rafter bays of the cathedralized portion of the roof from above and below. After the rigid board insulation was sealed to the framing with foam sealant, the remaining cavity depth was dense-packed with cellulose insulation.
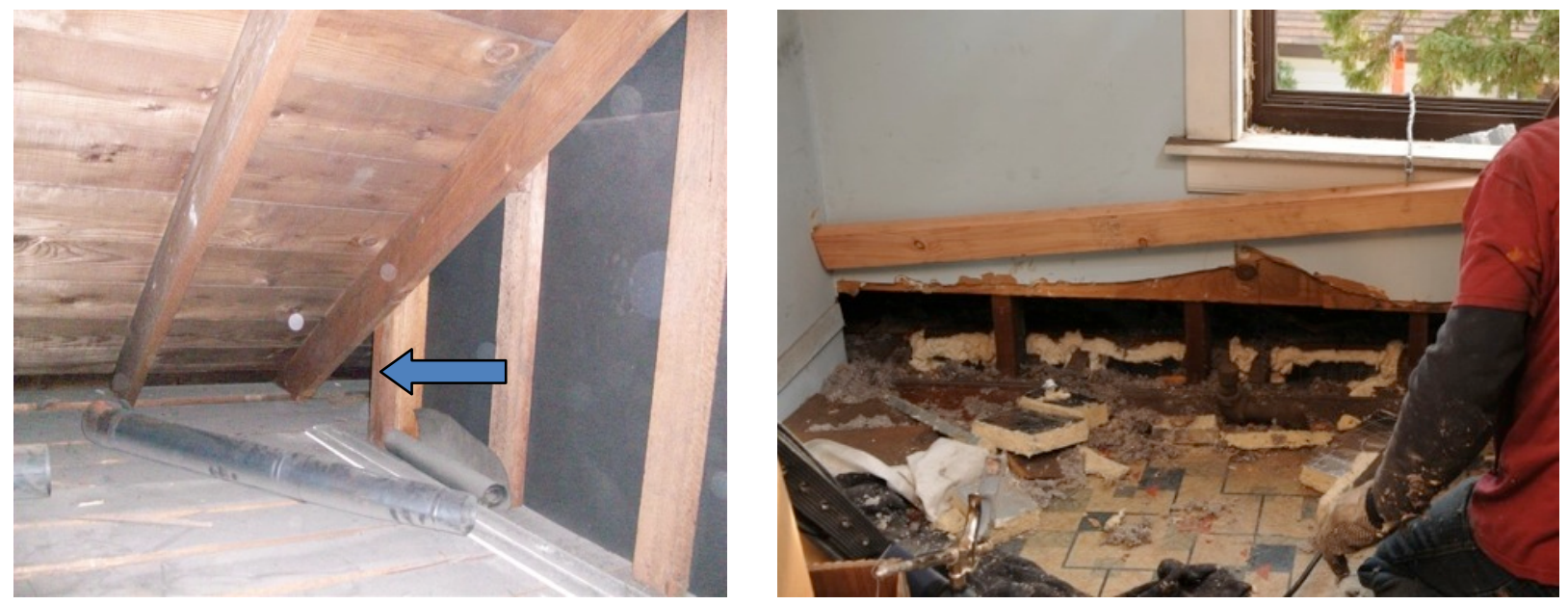

Figure 21. Left: Small space with limited access at face of dormer. Right: section of interior finish removed to allow air sealing (Photo credit: E. Haber, printed with permission) 


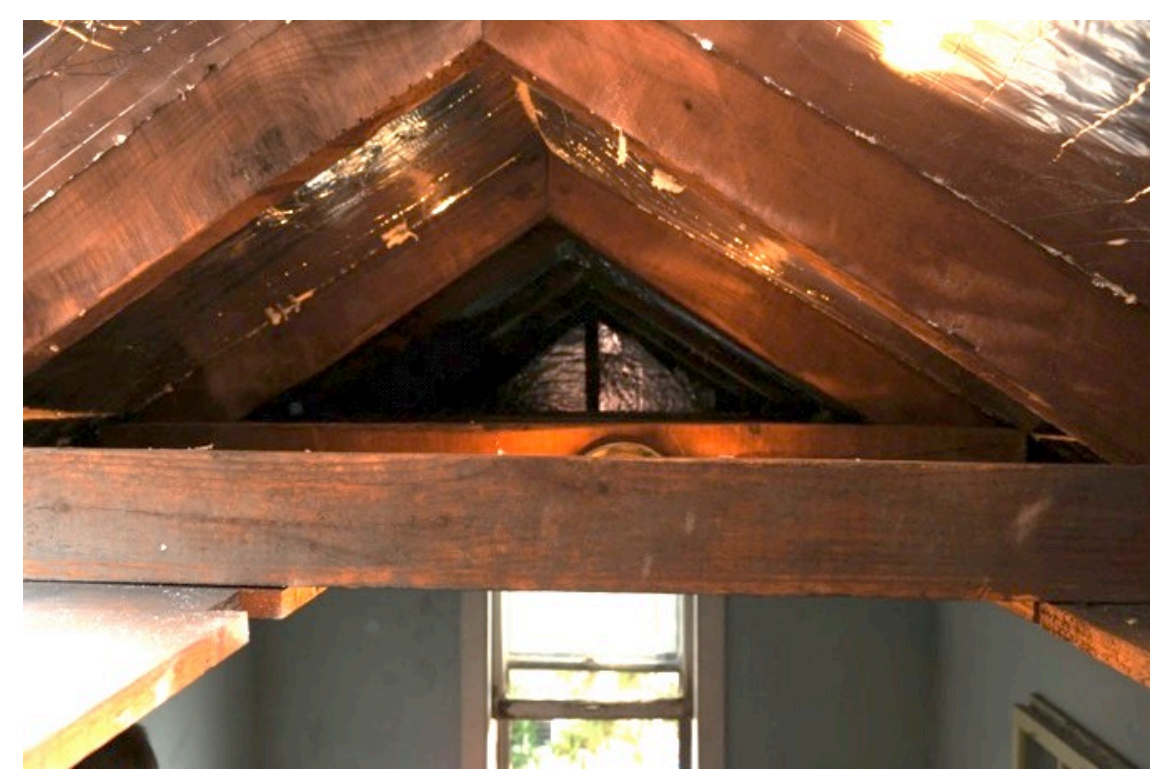

Figure 22. Foil-faced polyisocyanurate insulation installed above ceiling of finished room in attic (Photo credit: E. Haber, printed with permission)

\section{Rigid insulation board installed between roof framing}

Because of the difficulty of bringing 4'x8' sheets of material into the attic space, the implementing crews cut sheets of rigid insulation board into strips outside of the building. The contractor developed a practice of cutting the strips slightly narrower than measurements of the framing cavities in order to accommodate small variations in spacing without having to measure each bay and convey the measurement to the person cutting outside.

As seen in Figure 23 below, this practice of cutting the rigid board insulation can result in small gaps between the insulation board and the framing. While it is arguable that this gap may have a small negative impact by allowing convective air flow around the insulation, the small gap may also contribute positively to redistribution of moisture concentrations. The contractor learned that this gap facilitated sealing the rigid board foam to the rafters because it allowed the nozzle of the applicator to be drawn between the foam board and the rafter. This joint is likely to be more robust than a fillet joint between the smooth foil facing and the rough wood rafter. 


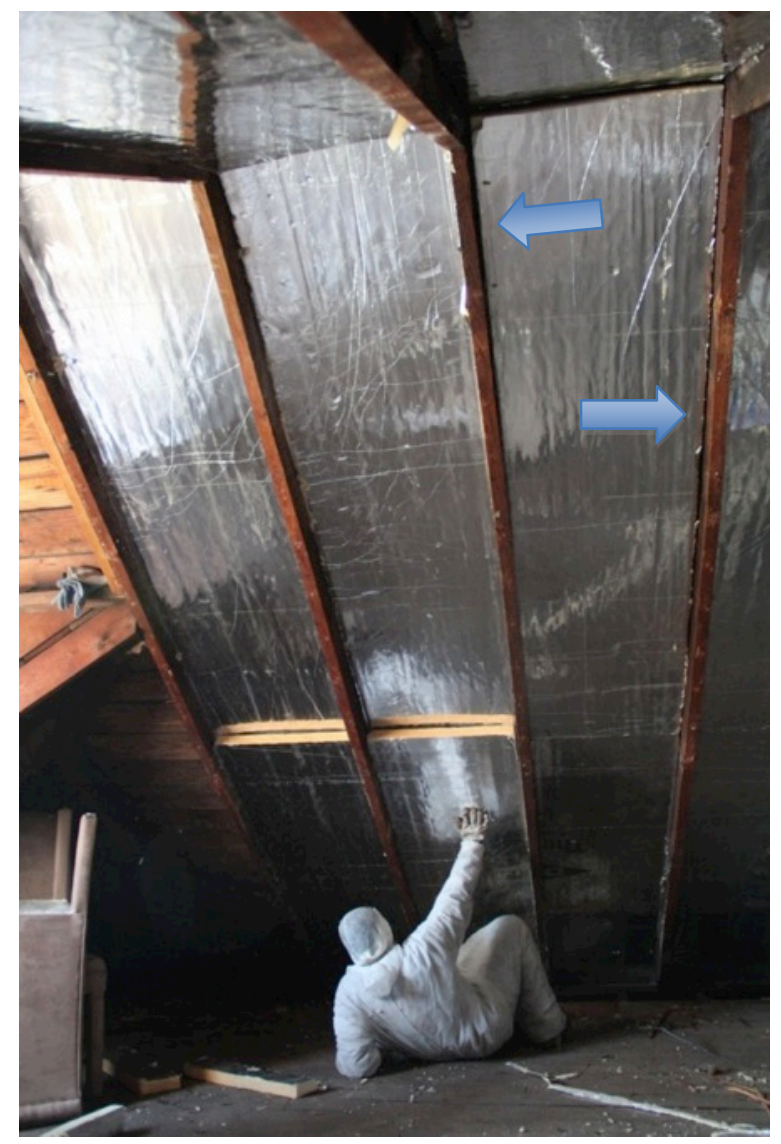

Figure 23. Foil-faced polyisocyanurate insulation fit into rafter framing cavities (Photo credit: $S$. Marchese, printed with permission)

\section{Sealing insulation board}

The roof rafter approach was observed to provide generally better access and substrate conditions for air sealing with two-part foam sealant.

At the prototype implementation of the roof rafter approach, a duct blaster fan was installed in a dormer window at one end of the attic to exhaust air and provide positive cross ventilation during application of two-part foam sealant. Measurements taken during and after application of the two-part foam showed that levels of unreacted components remained below occupational safety thresholds.

From the prototype implementation board sealing, it was apparent that the contractor's crews were adept at application of two-part foam sealant and understood the functional objective of the air sealing. It was also noted that mechanically induced cross-ventilation had not been standard practice for safe application of two-part foam in confined spaces. A more common practice is to open windows at two ends of the attic (where operable windows are present). During the heating season, the stack effect would enhance the effectiveness of this approach. A CEDA Assessor measured a passive pressure difference of $20 \mathrm{~Pa}$ during one winter time application of the passive cross-ventilation approach. 


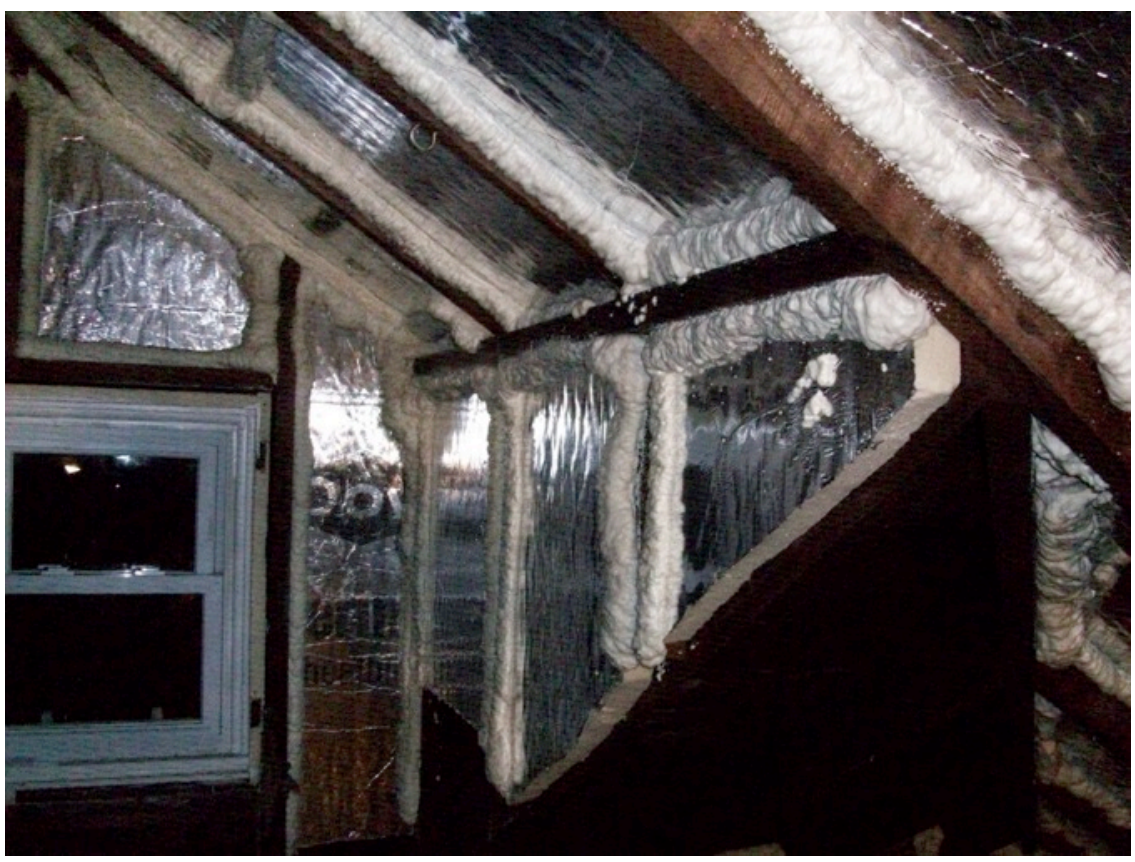

Figure 24. Foam sealant applied to seal foil-faced polyisocyanurate to surrounding framing. In this image the application of rigid insulation and foam sealant is not complete. (Photo credit: $E$. Haber, printed with permission)

\section{Air seal the furring cavity at the exterior wall}

This measure did not pose an implementation challenge once access had been created by removal of attic floorboards. Some of the CEDA Weatherization assessors developing work orders determined that air sealing at the top of the plumbing wall is useful in the roof rafter approach as the plumbing wall otherwise provides connections to the furring cavity through interstitial spaces.

\section{Extending depth of framing cavities}

Rather than using dimensional lumber, the contractor chose to extend the rafter cavity depth by adhering strips of extruded polystyrene to the bottom of the rafters, then fastening wood strapping to the rafters through the polystyrene. This measure provided both labor and cost savings. There would also be a small benefit to thermal performance through reduction of wood framing thermal bridging.

After one iteration of the roof rafter approach, the contractor determined that the bottom cord of the rafter should be extended prior to "foaming in" of the rigid board insulation installed between rafters. This avoided having to trim overspray in order to allow installation of furring to the bottom of the roof rafters. 

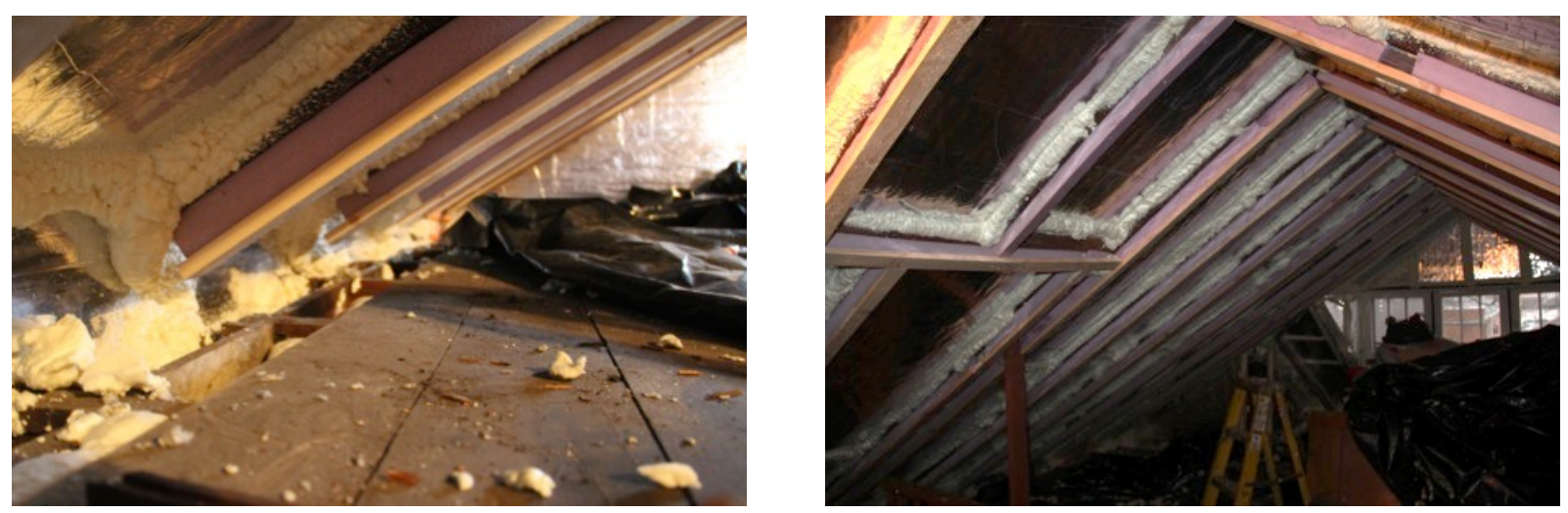

Figure 25. Left: Extruded polystyrene and wood furring strip used to extend rafter cavity; Right: Attic with rafter cavities extended in preparation for mineral fiber insulation (Photo credit: $S$. Marchese, printed with permission)

\section{Installing high-density mineral fiber batt insulation}

In most of the implementations of the roof rafter strategy, the contractor installed high-density fiberglass batt insulation with a nominal R-value of 21 to the inside of the foil-faced polyisocyanurate and covered with a simple house wrap. At the prototype implementation, the contractor insisted on the use of cellulose for the fibrous insulation and drywall rather house wrap over fibrous insulation.

Members of the crews commented that installation of batt insulation is generally faster than blown cellulose. CEDA assessors noted, however, that installation of batt insulation, even in this research project, seldom involves trimming of batts to fit irregular bays or to accommodate obstructions. One CEDA Assessor posited that installation of batt insulation according to best practices would not be less time-consuming than blown cellulose.
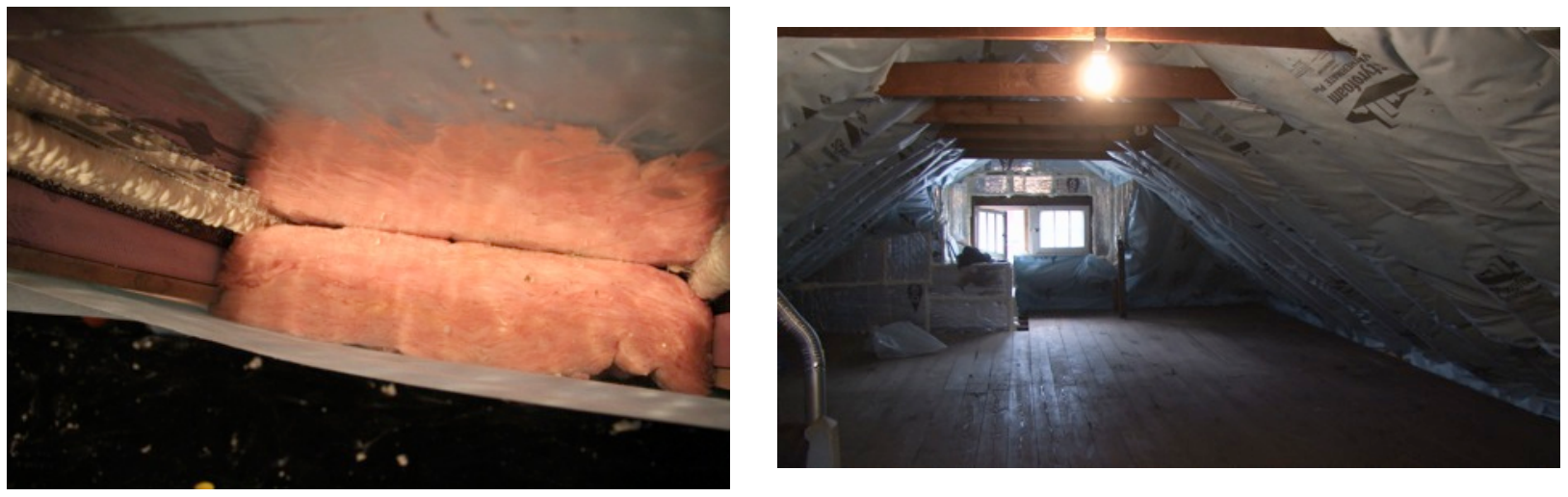

Figure 26. High density fiberglass batt in extended rafter cavity; Right: Completed roof rafter strategy (Photo credit: S. Marchese, printed with permission)

\section{Cover for mineral fiber insulation}

The homeowner was quite pleased with the drywall covering installed to the inside of the assembly at the prototype implementation. The difficulty that the weatherization program faces with installation of a gypsum wallboard covering is that it provides a disproportionate benefit to 
customers receiving this measure. Even if the contractor were to offer to install drywall for the same cost as the house wrap covering, this would create a situation where the weatherization program could be seen as using energy efficiency funding to create non-energy amenities for certain customers. Equal or equivalent benefit for customers is a goal of CEDA's regular weatherization program. For subsequent test homes, a house wrap was used as the material to cover the fibrous insulation and prevent loose fibers from circulating into the living space.

\section{Air Leakage Testing}

As part of the initial assessment of each candidate test home, CEDA Weatherization conducted air leakage measurements of the pre-retrofit conditions. Testing was also conducted after completion of the package of retrofit measures as part of regular follow-up quality control. For this research project, air leakage measurements were also taken with the home in different configurations in terms of opening or closing basements, attic, and porches to the main living space on the first floor.

At the time of this writing, three instances of the attic deck insulation and air sealing approach have been implemented and five instances of the roof rafter insulation and air sealing approach have been implemented. Relative reductions in air leakage measurement reduction are presented in Figure 27 below for the testing configuration with an open door between the main basement and the main living area for homes with both pre- and post-retrofit testing data available. This configuration provided the most complete series of pre- and post-retrofit air leakage measurements. The testing data also show that the air leakage measurement changes very little (less than $6 \%$ in all cases where data is available) when the door to the basement is opened. ${ }^{4}$ The relative reductions provide a normalization of the air leakage reduction that is not subject to errors in interpreting or measuring the geometry of the buildings.

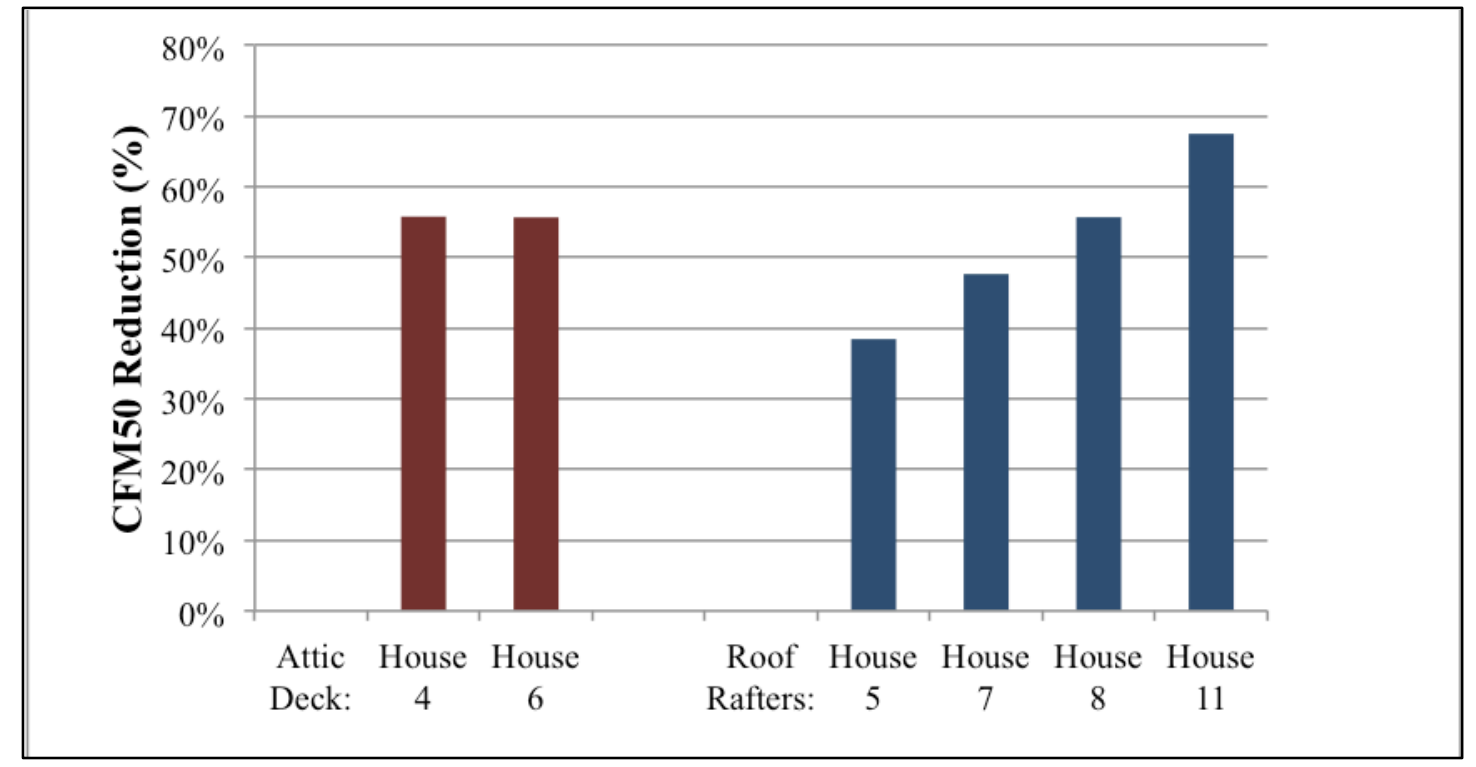

Figure 27. Air leakage reduction for attic deck and roof rafter strategies

\footnotetext{
${ }^{4}$ This observation is consistent with BSC's experience which finds that even with extraordinary efforts to separate the basement from living space above, basements remain fairly well connected to the living space.
} 
On average, the relative air leakage reduction achieved through the roof rafter approach is very similar to the relative air leakage reductions achieved through the attic deck approach (approximately 55\%). The CEDA Weatherization staff also report that the implementing crews seemed to become more adapt at implementing the roof rafter approach during the course of the research. This anecdotal observation coincides with the trend apparent in the air leakage reduction measured at these test homes.

A potential performance vulnerability with the roof rafter approach is that it leaves existing attic dormer windows in place. These may be significant sources of air leakage and conductive heat loss/gain.

\section{Measure Costs}

The total costs for measures implemented in this research project do not reflect typical weatherization budgets. In CEDA Weatherization's regular weatherization program, the expenditure limit per home is $\$ 5,200$. The special funding that enabled this research project allows up to $\$ 15,000$ to be allocated in each of ten homes.

The detailed work orders issued to the implementing contractor allow for itemization of the costs for each of the two retrofit strategies. The tables below summarize the measure costs including both labor and material costs, represented in work orders.

Table 2. Attic Floor Insulating and Air Sealing Strategy Cost Components

\begin{tabular}{|c|c|c|c|}
\hline Component/Measure & $\begin{array}{l}\text { Unit Cost } \\
\text { \$ / S.F. or Unit }\end{array}$ & $\begin{array}{l}\text { Cost / Project } \\
\text { Average }\end{array}$ & $\begin{array}{l}\text { Cost / Project } \\
\text { Range }\end{array}$ \\
\hline $\begin{array}{l}\text { Remove all attic } \\
\text { flooring }\end{array}$ & $\$ 0.35 / \mathrm{sf}$ & $\$ 240$ & $\$ 0-\$ 514$ \\
\hline $\begin{array}{l}\text { Air Sealing package } \\
\text { and contractor kit }\end{array}$ & & $\$ 630$ & $\$ 630$ \\
\hline $\begin{array}{l}\text { Box in exhaust fan } \\
\text { housing }\end{array}$ & $\$ 26.00$ ea & $\$ 13$ & $\$ 26.00$ \\
\hline Box in recessed light & $\$ 26.00$ ea & $\$ 30$ & $\$ 0-\$ 270$ \\
\hline Attic hatch cover & & $\$ 162$ & $\$ 162$ \\
\hline Attic stair cover & & $\$ 287$ & $\$ 228-\$ 412$ \\
\hline Storage platform & & $\$ 384$ & $\$ 44-\$ 1,055$ \\
\hline Soffit chutes & $\$ 3.62$ ea & $\$ 238$ & $\$ 167-\$ 344$ \\
\hline $\begin{array}{l}\text { Cellulose R-40 11" } \\
\text { settled density }\end{array}$ & $\begin{array}{l}\$ 1.29-\$ 1.32 / \\
\text { sf }\end{array}$ & $\$ 1,620$ & $\$ 1,250-\$ 2,312$ \\
\hline other & & $\$ 117$ & $\$ 0-\$ 464$ \\
\hline $\begin{array}{l}\text { Subtotal for Attic } \\
\text { Floor Approach }\end{array}$ & & $\$ 3,493$ & $\$ 2,944-\$ 5,574$ \\
\hline
\end{tabular}


Table 3. Roof Rafter Insulating and Air Sealing Strategy Cost Components

\begin{tabular}{|c|c|c|c|}
\hline & Unit Cost & Cost / Project & Cost / Project \\
\hline Component/Measure & \$ / S.F. or Unit & Average & Range \\
\hline $\begin{array}{l}\text { Remove pull floor } \\
\text { boards around } \\
\text { perimeter of attic }\end{array}$ & $\$ 0.35 / \mathrm{sf}$ & $\$ 185$ & $\$ 64-386$ \\
\hline $\begin{array}{l}\text { Thermax rigid board } \\
\text { insulation }\end{array}$ & $\$ 4.75 / \mathrm{sf}$ & $\$ 7,633$ & $\$ 6,945-\$ 8,954$ \\
\hline $\begin{array}{l}\text { Air Sealing package } \\
\text { and contractor kit }\end{array}$ & & $\$ 630$ & $\$ 630$ \\
\hline $\begin{array}{l}\text { XPS and } 1 \times 2 \text { wood } \\
\text { strapping for } \\
\text { extending rafters }\end{array}$ & $\begin{array}{l}\$ 0.42 \text { / linear } \\
\text { foot of rafter }\end{array}$ & $\$ 342$ & $\$ 314-\$ 386$ \\
\hline $\begin{array}{l}\text { Fasteners and } \\
\text { adhesive }\end{array}$ & $\begin{array}{l}\text { \$12/box } \\
\$ 2.81 / \text { tube }\end{array}$ & $\$ 78$ & $\$ 14-\$ 94$ \\
\hline $\begin{array}{l}\text { High density } \\
\text { fiberglass batt (R21) }\end{array}$ & $\$ 1.09 / \mathrm{sf}$ & $\$ 1,787$ & $\$ 1,594-\$ 2,055$ \\
\hline $\begin{array}{l}\text { Weathermate } \\
\text { insulation cover }\end{array}$ & $\$ 0.21 / \mathrm{sf}$ & $\$ 530$ & $\$ 189-\$ 1,896$ \\
\hline other & & $\$ 1,670$ & $\$ 1,285-\$ 1,912$ \\
\hline $\begin{array}{l}\text { Subtotal for Roof } \\
\text { Rafter Approach }\end{array}$ & & $\$ 11,087$ & $\$ 10,130-\$ 14,035$ \\
\hline
\end{tabular}

Within each test home for which a work order was prepared for both the roof rafter and the attic deck approach, the cost for the roof rafter approach is $\$ 7,080$ more than the attic deck approach, on average.

An important measure cost data consideration is that these reflect prices negotiated prior to implementation of most of the test home retrofits. It is reasonable to expect that some of these costs would be adjusted for future retrofits employing these strategies. For example, even though during the course of the project the contractor reduced the labor time to remove floorboards, the cost used in the work orders still falls well short of the contractor's total cost to remove the attic floorboards. If the unit price paid for this measure were adjusted to better reflect the contractor's cost, both strategies would have a high cost but the change to the attic deck strategy would be greater.

The attic stair covers were observed to function very well. The counterweight systems provided easy operability to the large stair covers, allowing them to open fully with minimal effort and also to remain firmly closed. This measure represented a departure from standard practice for attic deck insulation in the regular weatherization program. Given that it is difficult to directly 
associate the easy operability with energy savings, it is unlikely that the counterweight assembly could be an allowable cost in standard weatherization activity. However, it is arguable that this measure is necessary for the effective and lasting performance of the attic deck air sealing and insulation measure.

There are other factors that may have inflated the cost of the roof rafter strategy relative to the attic deck strategy. In implementation of the attic deck strategy, floorboards, if present, are removed from the entire attic floor. In the roof rafter strategy implementation, the floorboards are only removed in a strip above the exterior wall. This difference does not appear to be reflected in the work orders. In the work orders itemizing costs for both the roof rafter and attic deck strategies, the price allowed for attic floorboard removal with the roof rafter strategy was only slightly less — sometime the same - as the price allowed for floorboard removal associated with the attic deck strategy.

The roof rafter strategy specifications were developed to respond to then-current capabilities of CEDA Weatherization contractors. The contractors eligible to perform the research implementation did not have access to spray foam application equipment appropriate for insulation of framing cavities. Cutting the rigid board insulation to size and installing it between rafters and air sealing of the rigid insulation would likely represent more labor input than would be required for application of closed-cell spray-applied polyurethane foam insulation in the framing cavities. A foam plastic insulation material used in the attic would require a thermal barrier to meet code requirements relative to fire protection. Use of a material such as gypsum wallboard would effectively render the attic a finished space. Thermax insulation was specified as the rigid board insulation material. As noted previously, the local construction material market sees a significant cost premium for rigid foam insulation board carrying the appropriate fire rating.

CEDA has learned that the contractor implementing the work in the research project has decided to purchase spray foam installation equipment. This appears to be an indication that the contractor has recognized application of closed-cell SPF as a more cost-effective method for insulating and air sealing in the plane of the roof. 


\section{BEopt Modeling}

\section{Modeling Goals}

BEopt modeling was performed in order to estimate the energy use and provide a representation of cost effectiveness for the retrofit strategies. Since retrofit strategies were similar for each of the 10 homes, and they are of similar size and limited geometry data was available, a model of one representative home, Test Home 2, was created (Figure 28).

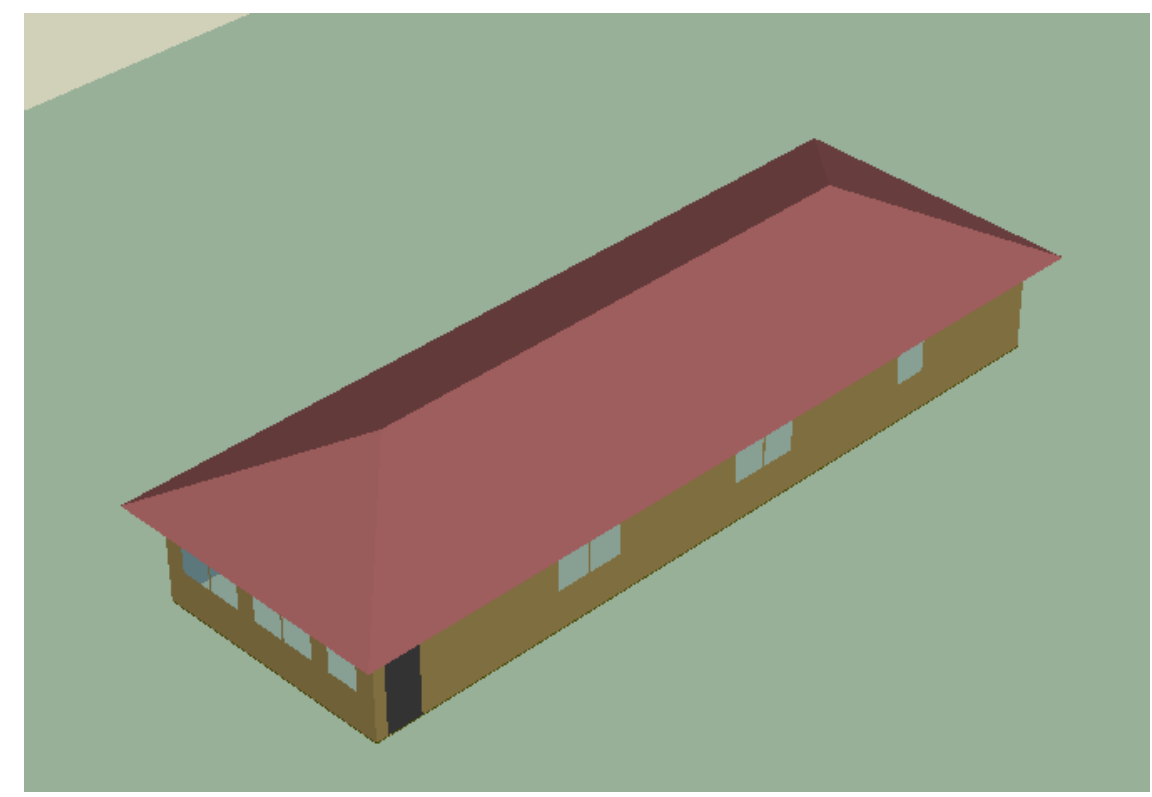

Figure 28. BEopt image of representative house model

Due to current software limitations, several of the important retrofit strategies used in this project cannot be readily captured with BEopt. In addition to measures beneficial to long-term durability but not energy use, such as the repair of roof leaks, the following details could not be modeled:

- Air sealing of the furring cavity at the exterior wall; this left an air channel stretching from the basement to the top of the walls (Figure 2)

- Installation and air-sealing of foil-faced polyisocyanurate at the intersection of the masonry wall to the roof (Figure 4)

- Insulation of the attic ladder-access hatch.

In addition to these attic/roof improvements and crawlspace insulation, exhaust-only ventilation and programmable thermostats were installed. Other home retrofit measures such as boiler replacement were considered in the cost optimization but ultimately fell outside the scope of work due to the fixed money available per house and the constraints of occupied retrofit.

The roof rafter insulation and air sealing strategy, by the necessary use of foam sealant as part of the insulation installation, includes the major portion of air sealing during installation of the 
insulation. In the case of cellulose on the attic floor, air sealing takes place before the insulation is blown in, and overlaps work that is needed for fire safety (boxes around luminaires), and to keep cellulose out of the living area. In both these cases, separating the cost of air sealing from that for insulation is not realistic.

The main directional decisions to be made regarding the treatment of each test home are between attic floor and rafter insulation. As discussed elsewhere in the report, these decisions are made largely on the basis of access, feasibility, and the occupants' desire for more usable space. The cost data entered in BEopt does not reflect the particular difficulties of insulating certain crawlspaces on the walls, nor does the annualized cost metric assess the added value of increasing or preserving dry, heated living or storage area.

\section{Modeling Inputs}

Two distinct modeling exercises were performed. The first modeling exercise estimates the energy usage in four different scenarios representing 1) the existing condition, 2) improvements unrelated to the attic/roof, 3) the attic deck insulation, and 4) the roof rafter insulation. These four scenarios are outlined below:

- Existing conditions ("Pre-retrofit"). This includes an R-5 attic floor and uninsulated, walls, basement, and crawlspace. Hydronic heating is provided by an $80 \%$ AFUE gas boiler and cooling by 10 SEER window air conditioners. Building America Benchmark parameters are used where existing conditions are unknown. An airtightness of 10 $\mathrm{ACH} 50$ is used based on infiltration testing measurements of pre-retrofit conditions. No mechanical ventilation exists in this scenario, as observed in many of the homes.

- Improvements unrelated to the attic/roof ("T-Setback, Bath Exhaust, Crawlspace"). This upgrade consists of adding 2" ccSPF and 2" mineral wool to the crawlspace walls, adding a programmable thermostat, and installing an exhaust-only ventilation system. Infiltration is reduced by $10 \%$ at this step to reflect air flow control improvement resulting from the crawlspace treatment as well as program-standard weather stripping.

- Adding insulation to the attic deck ("Attic Deck"). This step consists of air-sealing the attic floor and adding 11 " of cellulose. Infiltration is reduced by 55\% from pre-retrofit conditions, corresponding to the average reduction observed by comparing pre- and postretrofit blower door measurement results.

- Adding insulation to the roof rafters ("Roof Rafters"). This scenario is an alternative to and not an addition to the "Attic Deck" scenario. This step consists of installing 3" of polyisocyanurate rigid board (R-20) and R-21 fiberglass batt between the roof rafters. The air sealing improvement relative to the pre-retrofit condition is also 55\% reflecting pre- and post-retrofit blower door measurement results for implementations of this strategy.

The second modeling exercise involved BEopt cost optimization showing the location of possible scenarios on the least-cost curve. A separate BEopt model in Retrofit Optimization Mode was used for energy and cost optimization analysis. 
Inputs used to describe the building components for the existing conditions case, post-retrofit case as well as for selected alternatives are presented with the cost information used in the table below. As noted in the table, the boiler and domestic hot water heater upgrade were priced but not implemented in the test homes. These items were included in the cost optimization model but not the four-scenario model.

Table 4. BEopt Modeling Inputs

\begin{tabular}{|c|c|c|c|c|}
\hline $\begin{array}{l}\text { Building } \\
\text { Component }\end{array}$ & $\begin{array}{l}\text { Pre-retrofit } \\
\text { Parameter }\end{array}$ & $\begin{array}{l}\text { Post-retrofit Parameter } \\
\text { and Alternatives }\end{array}$ & $\begin{array}{l}\text { Cost of } \\
\text { Upgrade }\end{array}$ & Cost source \\
\hline Infiltration & $10.3 \mathrm{ACH} 50$ & $4.6 \mathrm{ACH} 50$ (55\% reduction) & $\begin{array}{l}\text { Included } \\
\text { in other } \\
\text { costs }\end{array}$ & $\mathrm{N} / \mathrm{A}$ \\
\hline \multirow{2}{*}{$\begin{array}{l}\text { Attic/Roof } \\
\text { Insulation and } \\
\text { Air Sealing }\end{array}$} & R-5 attic floor & $\begin{array}{l}\text { R-40 attic deck ( } 11 \text { " of } \\
\text { cellulose) }\end{array}$ & $\$ 2.37 / \mathrm{sf}$ & $\begin{array}{l}\text { CEDA work } \\
\text { orders }\end{array}$ \\
\hline & & $\begin{array}{l}\mathrm{R}-41 \text { roof rafters ( } 3 \text { " polyiso } \\
\text { and } \mathrm{R}-21 \text { fiberglass batt) }\end{array}$ & $\$ 6.97 / \mathrm{sf}$ & $\begin{array}{l}\text { CEDA work } \\
\text { orders }\end{array}$ \\
\hline $\begin{array}{l}\text { Crawlspace } \\
\text { Insulation }\end{array}$ & Uninsulated & $\begin{array}{l}\text { R-20 (2" ccSPF and } 2 " \\
\text { mineral wool) on crawlspace } \\
\text { walls }\end{array}$ & $\$ 3.61 / \mathrm{sf}$ & $\begin{array}{l}\text { CEDA work } \\
\text { orders }\end{array}$ \\
\hline Basement & Uninsulated & $\begin{array}{l}\text { Uninsulated (no } \\
\text { improvement) }\end{array}$ & N/A & $\mathrm{N} / \mathrm{A}$ \\
\hline $\begin{array}{l}\text { Above-grade } \\
\text { walls }\end{array}$ & $\begin{array}{l}\text { Brick, } \\
\text { uninsulated }\end{array}$ & $\begin{array}{l}\text { Brick, uninsulated (no } \\
\text { improvement) }\end{array}$ & $\mathrm{N} / \mathrm{A}$ & N/A \\
\hline Ventilation & $\begin{array}{l}\text { No ventilation } \\
\text { provided }\end{array}$ & $\begin{array}{l}\text { Exhaust-only ventilation, } \\
50 \% \text { of ASHRAE } 62.2\end{array}$ & $\$ 438$ & $\begin{array}{l}\text { CEDA work } \\
\text { orders }\end{array}$ \\
\hline Thermostat & $\begin{array}{l}\text { Non- } \\
\text { programmable } \\
71 \text { F heating, } 78 \\
\text { F cooling }\end{array}$ & $\begin{array}{l}\text { Programmable thermostat } \\
\text { installed with } 65 \mathrm{~F} \text { heating set } \\
\text { back }\end{array}$ & $\$ 86.50$ & $\begin{array}{l}\text { CEDA work } \\
\text { orders }\end{array}$ \\
\hline Boiler & $\begin{array}{l}\text { Approximately } \\
80 \% \text { AFUE, gas- } \\
\text { fired }\end{array}$ & $\begin{array}{l}\text { Condensing, 94\% AFUE, } \\
\text { gas-fired }\end{array}$ & $\$ 6,389$ & $\begin{array}{l}\text { CEDA work } \\
\text { orders }\end{array}$ \\
\hline $\begin{array}{l}\text { Domestic hot } \\
\text { water heater }\end{array}$ & $\begin{array}{l}\text { Assume gas } \\
\text { standard, EF } \\
0.59\end{array}$ & $\begin{array}{l}\text { High efficiency, indirect } \\
\text { fired heater, modeled as } \\
\text { BEopt "gas premium, EF } \\
0.67 \text { " }\end{array}$ & $\$ 1,553$ & $\begin{array}{l}\text { CEDA work } \\
\text { orders }\end{array}$ \\
\hline
\end{tabular}




\section{Modeling Results}

As shown in Figure 29 and Figure 30, the "T-Setback, Bath Exhaust, Crawlspace" step results in an improvement of 3\% from the baseline Pre-retrofit case while the "Attic Deck" and "Roof Rafter" steps result in improvements of $17.9 \%$ and $17.8 \%$ respectively. The equivalent insulation values of these two attic/roof options are very similar, though the surface area for heat transfer increases with the Roof Rafters option.

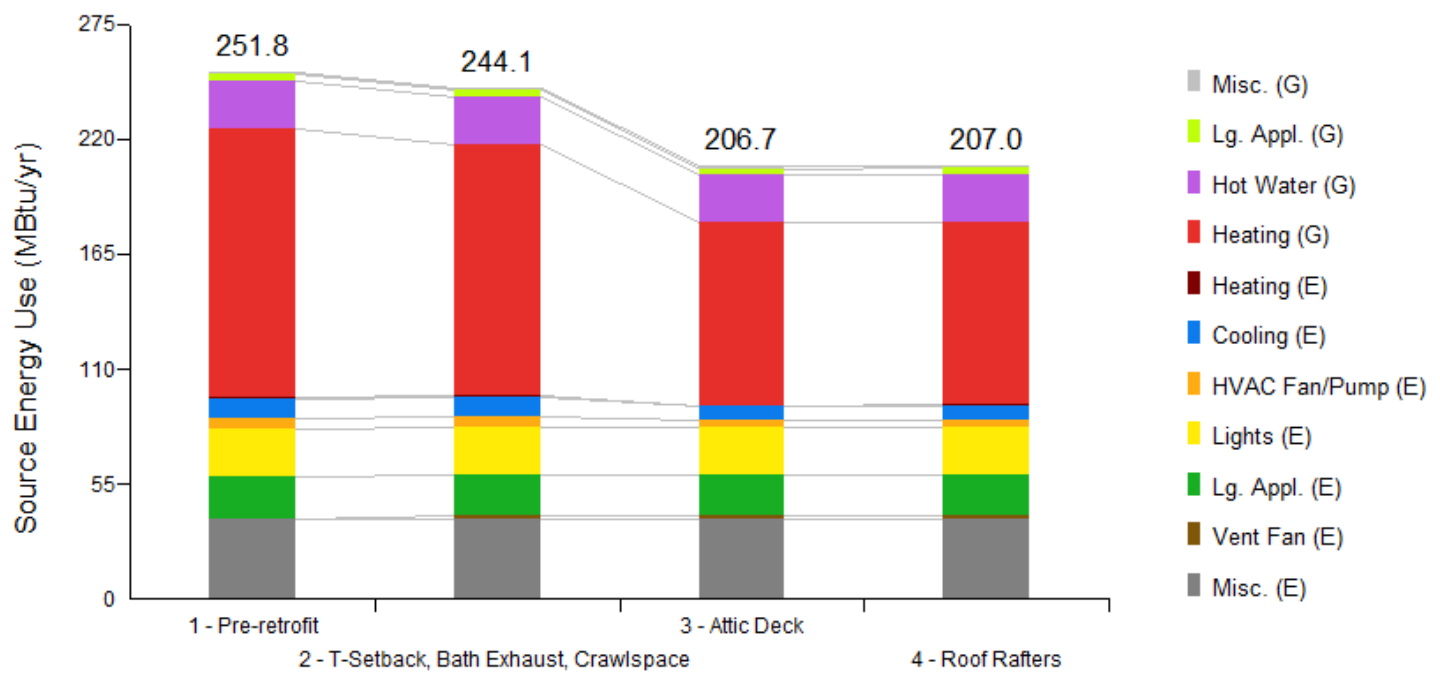

Figure 29. Source energy use bar graph of 4-scenario BEopt modeling results showing the pre-retrofit case, the programmable T-stat, bath exhaust, and crawlspace insulation step, and the two roof insulation options

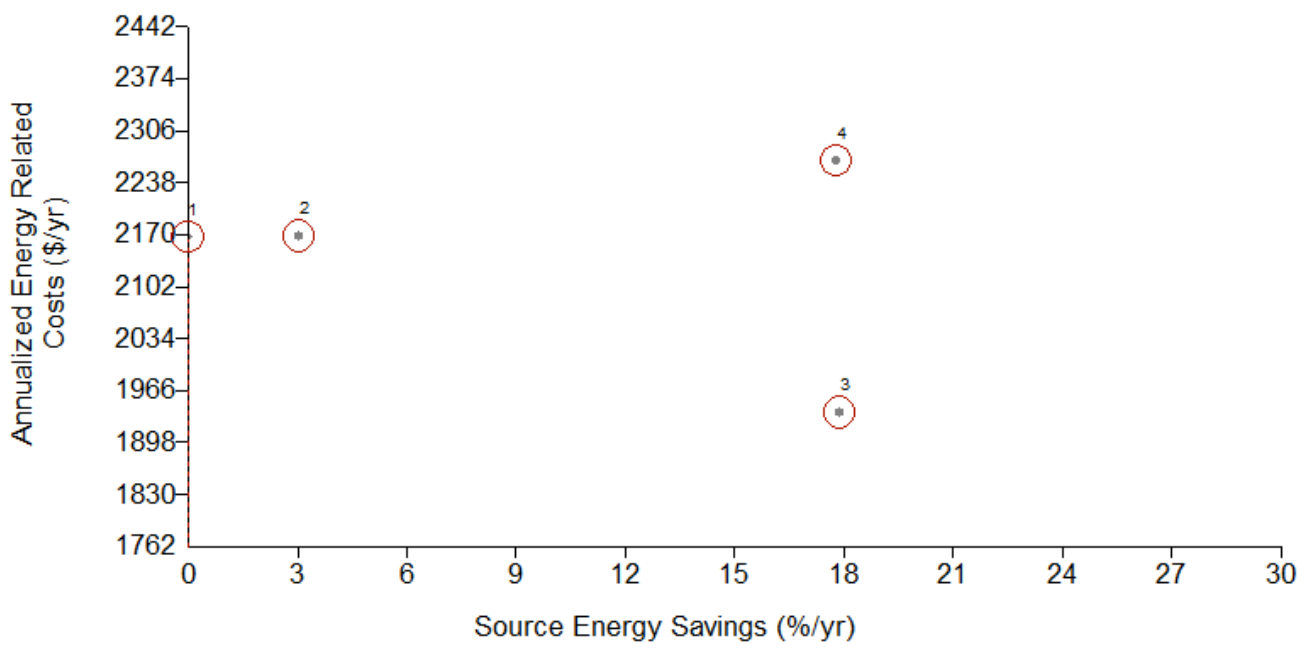

Figure 30. Costs-to-savings plot of 4-scenario BEopt modeling results showing the pre-retrofit case, the programmable T-stat, bath exhaust, and crawlspace insulation step, and the two roof insulation options 
The estimated $18 \%$ energy savings resulting from these improvements is reasonable considering the scope of work. While the combination of implemented strategies represents a substantial energy use reduction in absolute terms, the lack of insulation in the above-grade walls or basement limits the apparent relative energy use reduction. The installation of an exhaust ventilation system (represented in scenarios 2-4) increases energy use thus negating a portion of the savings achieved. However, ventilation systems are essential for indoor air quality; this is a tradeoff between energy use and occupant health and comfort.

This modeling exercise suggests that the energy performance of the attic deck approach and the roof rafter approaches is essentially the same. The modeling predicts that annualized energy related costs for the roof rafter approach are approximately $\$ 350$ per year more for the roof rafter approach.

Figure 31 below shows the results of the cost optimization model, using the parameters outlined in Table 4. The circled dot shortly above the low point of the least-cost curve represents the package of implemented upgrades that includes the attic deck insulation scenario. Above the least-cost curve is a similarly shaped arrangement of dots with higher costs. This represents various scenarios with the roof rafter insulation instead of attic deck insulation. While this option is significantly more expensive, it adds value to homeowners by providing another usable floor. Options further to the right represent scenarios that include the proposed boiler and domestic hot water heater upgrade. While these result in higher energy savings, they were not implemented due to cost constraints.

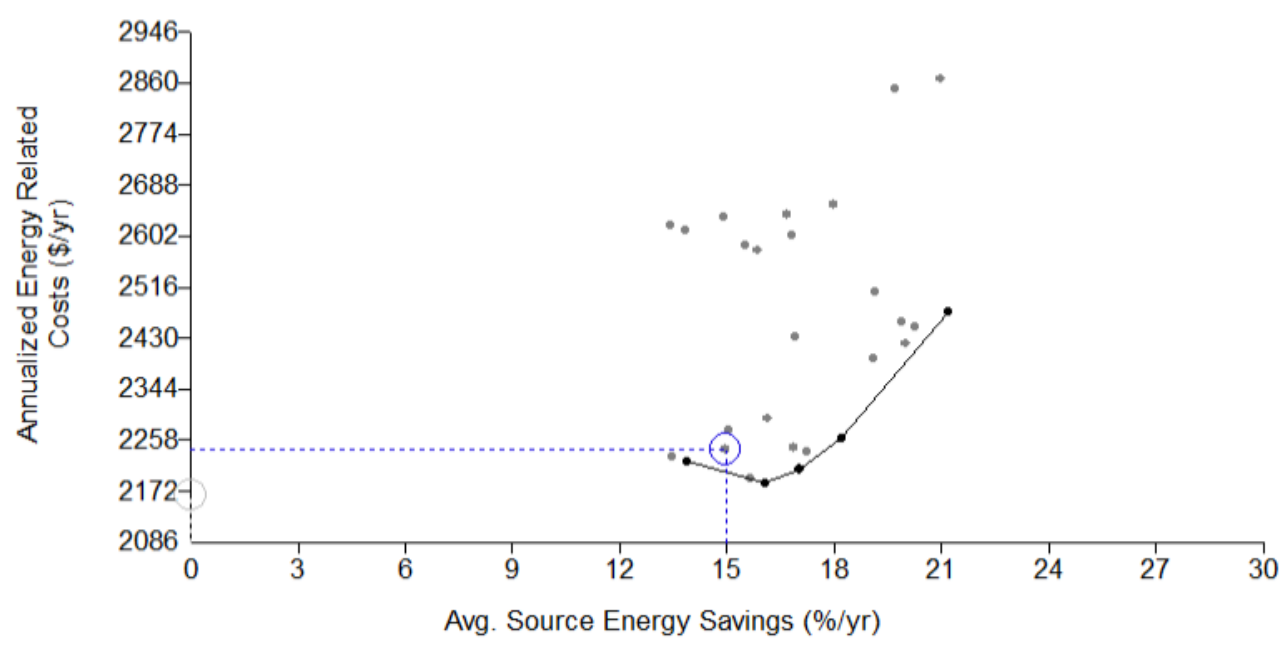

Figure 31. BEopt cost optimization curve 


\section{Recommendations for Future Work}

\section{Safe Installation Procedures}

For some reason, the safety protocols and controls employed in the professional SPF installation industry have not filtered down to the use of SPF from kits such as often used in a weatherization program context. There are some risk factors in installation of SPF that are, in fact, more acute in the weatherization and retrofit context due to the likelihood of encountering confined spaces. SPF application kits generally lack the technological safeguards of professional equipment used for application of SPF as a whole building insulation system. Safe installation protocols for SPF that can be used across weatherization programs are needed.

\section{Monitoring}

The quantitative performance measurement of this research has been air leakage reduction as measured by blower door testing. A more comprehensive assessment of the impact of measures implemented would combine utility bill analysis, building operation and use information, as well as information on how the use of buildings in the study may have changed since retrofit.

Utility bill analysis would help to quantify energy performance benefits. Temperature and relative humidity $(\mathrm{RH})$ monitoring would be a useful supplement to billing analysis as it will help to gauge comfort conditions and the presence of take-back phenomenon (i.e. where residents operate the building at higher levels of comfort than prior to the retrofit). Data logging equipment could be deployed to record temperature and relative humidity conditions within the building after implementation of the measures. Temperature and relative humidity data could also be used to assess performance of attic/roof thermal control measures and to supplement qualitative assessment of comfort conditions given by residents of test homes/buildings.

\section{Generic Details}

Details and implementation procedures outlined in this research could be further developed to allow wider dissemination and use. Some of the details and procedures developed for conditions encountered in this research are likely to have applicability in many more homes.

\section{Alternate Strategies to Unvented Roof Retrofit}

Cost information obtained through this research shows that the fire-rated rigid foam insulation represents a relatively high material and installation cost. The research scope did not allow exploration of a wide array of material combinations for the strategies employed. For example, the research was not able to assess whether insulation and air sealing of the attic with the use of SPF and an approved thermal barrier might prove a more cost-effective approach to insulating and air sealing at the plane of the roof. A broader array of tested and demonstrated material combinations might prove useful across markets with varying relative costs.

Exterior insulation implemented in conjunction with regular roof replacement may also provide interesting cost and performance synergies. 


\section{Conclusions}

\section{Appropriate Conditions:}

This research examines two distinct strategies for insulating and air sealing the top of buildings: attic deck insulation and air sealing, and roof rafter insulation and air sealing.

Selecting the appropriate strategy for any one home requires careful consideration of the particular conditions and use circumstances of the home. Although identification of the appropriate strategy for individual homes will not be formulaic, there are some factors likely to be pertinent across many cases. Attic deck insulation may be appropriate under the following conditions:

- The attic space is not used

- Limited storage of belongings in the attic

- Access is of simple geometry that can be covered by an insulated and gasketed hatch

- Floorboards are easily removed.

The following conditions tend to favor a roof rafter air sealing and insulation strategy:

- Attic space is actively used or there is finished space in attic

- Floor boards are difficult to remove

- Difficult access to critical air sealing areas at the attic floor

- Significant amount of resident items stored in the attic

- The household demonstrates an acute need for additional living space (e.g. if sleeping quarters located in the basement).

\section{Energy Performance:}

This research found that air leakage reduction and predicted energy performance of the different strategies to be very similar. The average air leakage measurement reduction was approximately $55 \%$ for both the attic deck strategy implementations and the roof rafter strategy implementations. Energy modeling of a representative brick bungalow configuration found that either strategy would reduce overall source energy use by approximately $18 \%$ relative to typical pre-retrofit conditions. Analysis of utility bills for the test homes is recommended as this would provide another valuable gauge to assess performance.

\section{Cost Performance:}

With the measures pricing used in the research project implementations, the cost for the roof rafter air sealing and insulation strategy was, on average, $\$ 7,080$ more than the cost for the attic deck air sealing and insulation strategy. While there is reason to expect that the roof rafter approach would be more costly (e.g. it uses a more expensive insulation material over a larger area), there are also factors that would tend to reduce the cost difference between the two strategies. 
As noted above, the unit price paid in the research implementations for removing attic floorboards is too low to support sustained implementation of this measure. An increase in cost for removal of attic floorboards would affect the attic deck strategy more than the roof rafter strategy. Some measures implemented in the research were assumed to be similar to measures in the regular program and priced accordingly. When following best practice guidelines, the contractor found that access of critical leakage areas at the attic floor and preparation of the substrate for air sealing to be considerably more involved than in general weatherization program activity. The costs for properly air sealing common air leakage sites such as bath fan housings and recessed lights is likely to be more than presently allowed in the weatherization program pricing used for the research implementations.

It was observed that the contractor found ways to streamline the roof rafter approach through variations to specified measures and sequence of operations. Therefore, prices for measures unique to the roof rafter approach that were initially unfamiliar might be priced lower after implementation of the research.

The roof rafter strategy specifications were developed to respond to then-current capabilities of CEDA Weatherization contractors. As noted, the local construction material market sees a significant cost premium for rigid foam insulation board carrying the appropriate fire rating. The installation of rigid board insulation between framing is also relatively labor-intensive. It is likely that an unvented roof retrofit strategy based on closed cell SPF insulation would be more cost effective.

\section{Conditions Necessary for Performance:}

Removal of floorboards, where present, is a critical step in achieving effective air flow control as well as air flow control transitions. CEDA Weatherization reports that this is rarely done in regular weatherization activity and that the added cost might jeopardize the cost effectiveness of the overall weatherization package for a home.

Another critical performance factor is quality control assessment of air sealing prior to installation of insulation. While the research project allowed for in-process assessment of the work, typical weatherization activity does not provide third-party assessment of the work prior to installation of insulation. One approach to address this would be to reallocated program resources used for final verification of measures to in-process assessment. Another approach could be to structure contractor incentives such that contractors have a vested interest in performing their own quality control assessment at critical steps of the process.

Tight-fitting and well-insulated covers for attic access are important to the overall performance of the attic deck strategy. This becomes more important with larger walk-up access. It is also likely to be more challenging to provide an appropriate access cover over attic stair access.

Air leakage control performance — and, consequently, energy performance — of the roof rafter approach relies on installation of a continuous air flow control system. Generally, the air flow control system is able to be visually inspected from the attic interior. This approach is reliant on skill in application of foam sealant so that the sealant is applied where it is likely to have a durable bond to the substrate and establish a continuous seal. Windows present in attic dormers do represent a potential weakness of the air flow control. If the window sash provides 
particularly poor air leakage control (e.g. if glass is missing from sash), tight fitting storms, window rehabilitation or window replacement may be necessary to achieve robust air leakage reduction for the strategy.

\section{Conditions Necessary for Wider Adoption:}

Wider adoption of either approach evaluated in this research would require development, dissemination and acceptance of safe application protocols for two-part foam kits. This need arises from the technology of two-part foam kits as well as the frequent use (opportunity for occupational exposure) and likelihood of confined spaces in weatherization work.

With the substitution of one-part foam sealant for two-part foam sealant, the roof rafter strategy could be implemented by reasonably able homeowners or volunteers. However, because of the durability risks of improper implementation or specification, more evaluation and development of guidance materials would be needed before a "do-it-yourself" process is viable.

The cost of implementation is likely to represent the most persistent challenges to widespread adoption of both strategies (attic deck and roof rafter). In the case of the attic deck strategy, measures critical to performance (thorough air sealing, access covers) and acceptability (attic storage) must be included in the overall package of attic deck treatment. There is no reasonable way to associate specific energy savings with these supporting measures. Still, the temptation will be to attempt to individually evaluate energy savings cost effectiveness of measures within a larger strategy. This ignores the interdependence of various components of the larger strategy and risks installation of lower cost packages that fail to achieve performance objectives.

The test homes in this research project showed that the roof rafter insulation and air sealing strategy represents a significantly higher cost than the strategy of insulating and air sealing at the attic floor. It must also be acknowledged, however, that bringing (or maintaining) the attic space within the thermal enclosure can significantly enhance the home. In the context of weatherization programs, these non-energy benefits are typically not allowed in calculations of qualifying metrics. Under some funding scenarios, non-energy benefits might even be seen as detrimental to goals of providing equal benefit.

If the non-energy benefit of usable above-grade space were valued, the incremental cost to achieve this benefit might seem small by comparison. Even with possible distortions to measure costs encountered in this research project, the energy modeling predicts that annualized cost for roof rafter approach is approximately $\$ 350$ more than for the attic deck approach. This would appear to be a small premium for a measure that increases usage of conditioned above-grade floor area by approximately $50 \% .^{5}$

It is worthwhile noting that almost all of the homes involved in the research had in-use living space, including bedrooms, in the basement. Since the basements are characteristically subject to occasional flooding and other causes of elevated humidity, it bears consideration whether creating additional living space over the first floor and under the existing roof might create healthier living conditions than the basement as it is. Sleeping quarters observed in basements occupied a small portion of the basement area. Moving the sleeping areas from basements would

\footnotetext{
${ }^{5}$ This is a gross estimate of the increased conditioned floor area based on an assumption that approximately half of the attic floor area would have a ceiling height that is too low to consider the area as useable living space.
} 
be the highest indoor air quality priority and could easily be accommodated within the conditioned attic space.

One possible approach to reconciling both the higher cost and greater use benefit of the insulated attic approach may be to establish some kind of cost sharing with homeowners for this strategy. Still, the higher cost of this measure, regardless of whether it is a shared cost, makes it unlikely that it will pass cost effectiveness screening for most weatherization programs. 


\title{
11 Appendices
}

\section{Appendix A: Sample work scope guidance memo}

Building
DSCience
Corporation

\section{Memo}

\author{
DATE: $\quad$ February 17,2011 \\ TO: $\quad$ Cassandra Fricke, Steve Marchese, Jason West, Terry Petersen / CEDA \\ FROM: Ken Neuhauser / Building Science Corporation (BSC) \\ RE: Work scope guidance: 1) Roof rafter treatment, 2) Attic storage platform, 3) Foundation wall insulation \\ CC: John Hamilton / CEDA; Joseph Lstiburek, Betsy Pettit / BSC
}

The recommendations below are offered to guide the development of contractor work scopes for work conducted under the joint CEDA-BSC Building America research project. Please do not hesitate to contact me if you have questions on the recommendations.

\section{Insulation of roof slope below the roof deck (between rafters):}

First, fix roof leaks. If the allowance for patching and flashing in the weatherization program is not adequate to fix the roof leaks, defer thermal work and refer home to roof repair program. This would also apply to the approach of air sealing and insulating at the attic floor plane.

Specification: 3" Thermax TM polyisocyanurate rigid insulation board, in two $1 \frac{1}{2} 2^{\prime \prime}$ layers. Install insulation board between rafters and in contact with roof sheathing. Joints between boards in successive layers offset by at least 8 ". Insulation board to fit snuggly between framing. If friction fit does not provide firm support, temporarily secure insulation board by toenail fastening to framing. Seal insulation board to surrounding framing, seal joints between boards, and seal any penetrations through insulation boards with two-part closed-cell spray-applied foam sealant following safe application protocol [Reference protocol developed for CEDA by Fitzgerald]. Sister lumber onto bottom cord of rafter framing to allow installation of high-density R21 fiberglass batt, or R23 mineral fiber batt insulation. Attach Dow Weathermate ${ }^{\circledR}$ or Weathermate Plus ${ }^{\circledR}$ housewrap to sistered lumber to provide a continuous covering over the fibrous insulation.

Note: whether the sistered lumber is $2 \times 3,2 \times 4$ or other depends upon the rafter depth. Having an insulation cavity for the fibrous insulation that is $1 / 2$ " shallower than the nominal thickness of the fibrous insulation is o.k. if this allows use of standard lumber sizes. Having an insulation cavity that is deeper than the nominal thickness is not acceptable.

\section{Cellulose fibrous insulation alternate:}

If using dense-packed cellulose for the air permeable insulation to the interior of the rigid insulation board, the roof rafters must be sistered to provide a cavity of sufficient depth to accommodate a cellulose installation achieving R20. The housewrap must be secured to the sistered roof rafters with cap nails or battens.

\section{XPS rigid foam board insulation alternate:}

XPS insulation may be used in combination with Thermax in the air impermeable rigid board insulation layer. Specification would be similar to above with the exception that 2" XPS rigid insulation board is installed between rafters and in contact with the roof sheathing, followed by $11 / 2$ " Thermax ${ }^{\mathrm{TM}}$ polyisocyanurate rigid insulation board installed between rafters and in contact with the XPS insulation board.

\section{Storage Platform:}

The target thermal performance for attic/roof insulation is assumed to be R40. When an attic floor is insulated to this level with cellulose, the depth of the cellulose will typically be significantly greater than the depth of framing. Because this will render the attic largely unusable as a storage space [in fact, when the thermal enclosure is implemented at the attic floor, frequent access to the attic space should be avoided/discouraged] the contractor may wish to be able to provide the customer with a small storage platform in the attic.

The following approaches to constructing a storage deck would be acceptable:

1) Raise a plywood platform on braced $2 \times 6$ framing running perpendicular to attic floor framing/ceiling joists, or 
2) Lay rigid insulation board to a thickness of 4 " (XPS) or 3" (polyiso) on the ceiling joists and fasten $1 / 2$ " plywood or OSB to the ceiling joists through the insulation.

Both of these assume $\sim 51 / 2$ " ceiling joist depth and that the cavity beneath the storage platform will be dense-packed with insulation. Both of these approaches must employ insulation dams at the sides of the platform to keep insulation off the platform and, more importantly, to mark the edge of the platform so that people don't mistakenly step off. The insulation dams should be at least $4 "$ above the anticipated height of the insulation.

\section{Insulation of foundation walls:}

Some homes present an opportunity to insulate crawlspace or basement foundation walls. Special considerations and mitigation will apply to foundation walls subject to capillarity where framing supported by the wall is within 1 foot of exterior grade.

\section{Basement foundation wall insulation}

Basements in CEDA customer homes are assumed to be typically finished or semi-finished spaces. The following are recommended approaches for basement foundation walls:

1) Proprietary exposure-rated insulation and finish system: 2 "Thermax Heavy Duty Insulation installed to foundation wall with PVC interlocking "T" fastening system or mechanical fasteners. Seal entire perimeter of rigid insulation layer to foundation wall with closed-cell foam sealant. Seal exposed seams with foil tape matching finish color of insulation panels. Provide $1 / 8$ " weep holes between bottom of insulation panel and floor at 24 " o.c.

2) Rigid insulation board and thermal barrier: $2^{\prime \prime}$ XPS insulation board installed to foundation wall with mechanical fasteners. Seal entire perimeter of rigid insulation layer to foundation wall with closed-cell foam sealant or foamcompatible adhesive. Seal seams between insulation boards with compatible construction tape or foam-compatible adhesive. Provide 1/8" weep holes between bottom of insulation panel and floor at $24^{\prime \prime}$ o.c. Construct stud wall of $1-5 / 8$ " metal studs to interior of rigid insulation board. Bottom track of stud wall to be on capillary/thermal break consisting of a strip of $1^{\prime \prime}$ XPS insulation with a compressive strength of 25 PSI or greater. Install $12^{n}$ non-paperfaced gypsum wallboard to metal stud framing leaving $1 / 2 "$ between bottom of wallboard and floor.

3) Closed-cell spray foam and thermal barrier: Construct stud wall of $15 / 8$ " metal studs spaced $2^{\prime \prime}$ from foundation wall. Bottom track of stud wall to be on capillary/thermal break consisting of a strip of $1^{\prime \prime}$ XPS insulation with a compressive strength of $25 \mathrm{PSI}$ or greater. Apply $2-3^{\prime \prime}$ closed-cell spray foam insulation to the foundation wall following applicable application safety protocols. Install non-paper-faced gypsum wallboard to metal stud framing leaving $1 / 2$ " between bottom of wallboard and floor.

\section{Crawlspace foundation wall insulation}

The following are recommended approaches for crawlspace foundation walls :

1) Exposure-rated rigid insulation board: 2" Thermax foil-faced polyisocyanurate rigid insulation mechanically fastened to foundation wall. Seal entire perimeter of rigid insulation layer to foundation wall with closed-cell foam sealant. Seal exposed seams with foil tape. Provide $1 / 8^{\prime \prime}$ weep holes between bottom of insulation panel and floor at $24^{\prime \prime}$ o.c.

2) Closed-cell spray foam and thermal/ignition barrier: Apply $2-3^{n}$ closed-cell spray foam insulation to the foundation wall following applicable application safety protocols. Insulation can extend onto floor of crawlspace. Apply intumescent paint thermal barrier according to manufacturer's instructions to provide thermal barrier for the exposed foam. In some circumstances, use and access conditions of a crawlspace may permit application of the intumescent paint as an ignition barrier. Check local code and consider all possible future uses/alterations of the crawspace.

\section{Foundation wall-to-framing connection}

For each foundation insulation and crawlspace insulation option described above, recommended air sealing and insulation of the mud sill and rim joist area is as follows:

Apply 1-2" closed-cell spray foam insulation or 3-5" open-cell spray foam insulation to the perimeter framing or back side of brick following applicable application safety protocols. Ensure that foam coverage is continuous from underside of subfloor to top of foundation wall insulation system.

\section{Mitigation for framing supported on low-exposure, high-capillary-potential foundation walls}

Where wood framing is supported on a brick foundation wall that has less than one foot of exposure above the exterior grade, there is an elevated risk of moisture transfer to the wood framing. Where such conditions exist the following mitigation must be undertaken prior to insulating and air sealing the framing supported on the foundation wall:

Drive metal sheet under the wood framing to provide a capillary break between the wood and the foundation wall. 


\section{u.s. DEPARTMENT OF | Energy Efficiency \& \\ Renewable Energy}

\section{Appendix B: Sample}

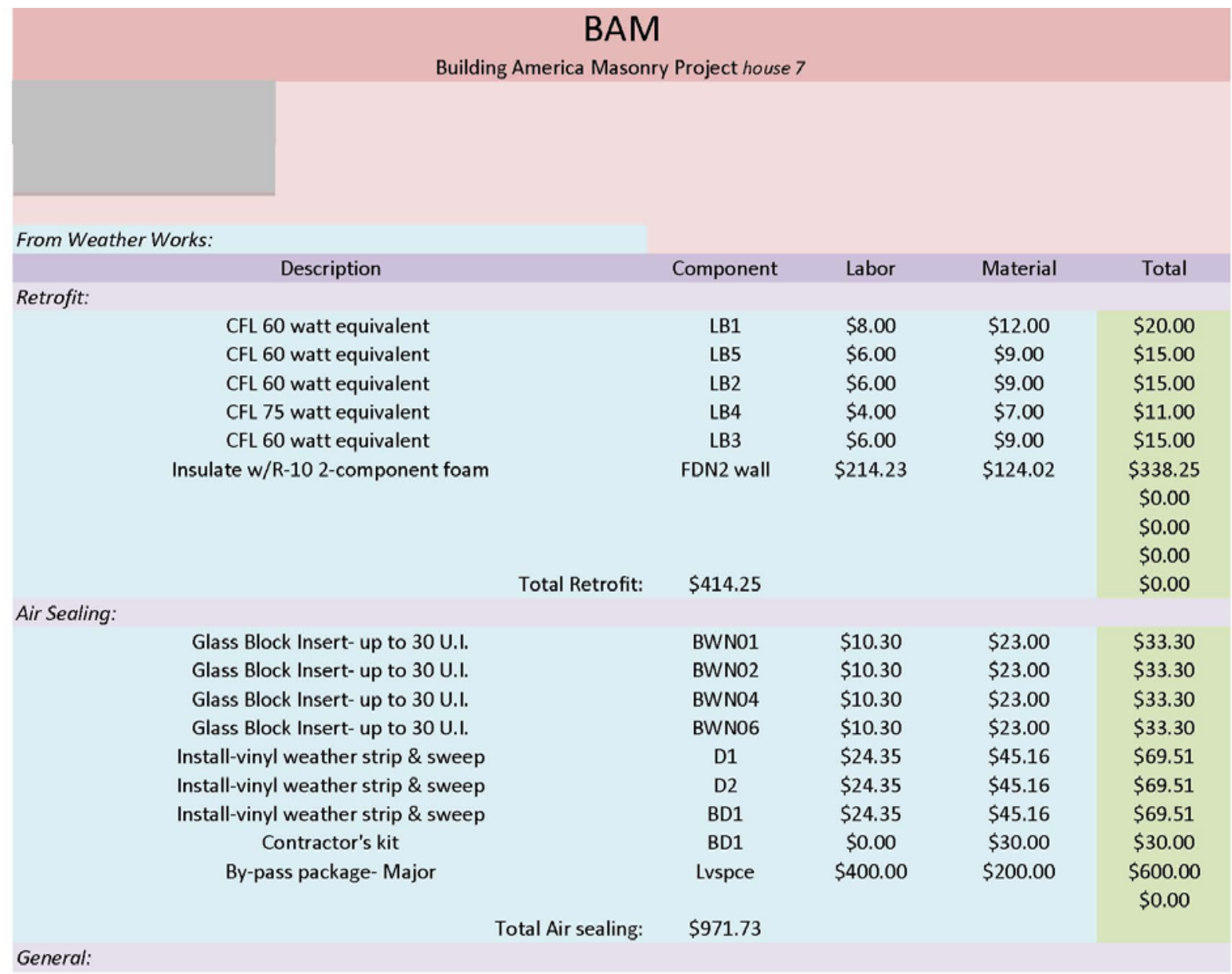




\begin{tabular}{|c|c|c|c|c|}
\hline Clean and Tune $80 \%$ forced air furnace & FRN1 & $\$ 125.00$ & $\$ 25.00$ & $\$ 150.00$ \\
\hline Ducting- transition w/filter rack \& cover & FRN1 & $\$ 79.50$ & $\$ 65.00$ & $\$ 144.50$ \\
\hline Install- Carbon Monoxide Detector (Basement) & $\mathrm{H} \& \mathrm{~S}$ & $\$ 5.30$ & $\$ 32.00$ & $\$ 37.30$ \\
\hline Trip charge Hazardous condition (gas leak) & H\&S & $\$ 42.40$ & $\$ 0.00$ & $\$ 42.40$ \\
\hline Hatch- Cut new hatch (FDN2 crawlspace) & BW2 & $\$ 21.20$ & $\$ 0.00$ & $\$ 21.20$ \\
\hline Hatch- Install new hatch (FDN2 crawlspace) & BW2 & $\$ 31.80$ & $\$ 27.64$ & $\$ 59.44$ \\
\hline Hatch- Insulate with R-20 and weatherstrip (FDN2 crawlspace) & BW2 & $\$ 9.55$ & $\$ 9.60$ & $\$ 19.15$ \\
\hline Insulate $\mathrm{w} / 2^{\prime \prime}$ mineral wool batt & BW2 & $\$ 62.01$ & $\$ 47.36$ & $\$ 109.37$ \\
\hline Ground moisture mitigation- install vapor barrier & FDN2 & $\$ 55.00$ & $\$ 30.00$ & $\$ 85.00$ \\
\hline Ground moisture mitigation- replace mudsill & BW2 & $\$ 139.16$ & $\$ 75.00$ & $\$ 214.16$ \\
\hline Insulate Band Joist w/R-10 2 component foam & $\mathrm{BJ} 2$ & $\$ 62.70$ & $\$ 36.30$ & $\$ 99.00$ \\
\hline Air Barrier install weathermate on crawl walls & BW2 & $\$ 13.53$ & $\$ 33.82$ & $\$ 47.35$ \\
\hline Attic General- pull floor boards & ATT1 & $\$ 63.60$ & $\$ 0.00$ & $\$ 63.60$ \\
\hline Install $1 \times 2$ wood furring to rafters & ATT1 & $\$ 120.00$ & $\$ 48.00$ & $\$ 168.00$ \\
\hline Install weathermate air barrier & ATT1 & $\$ 84.00$ & $\$ 210.00$ & $\$ 294.00$ \\
\hline Install high density fiberglass batt in rafter & ATT1 & $\$ 822.80$ & $\$ 807.80$ & $\$ 1,630.60$ \\
\hline Install $2 \times 2$ EPS foam furring strip & ATT1 & $\$ 80.00$ & $\$ 80.00$ & $\$ 160.00$ \\
\hline 4' screws and Adhesive & ATT1 & $\$ 0.00$ & $\$ 94.25$ & $\$ 94.25$ \\
\hline Exhaust-Install Broan QTRE100S Exhaust Fan & $H \& S$ & $\$ 92.00$ & $\$ 180.00$ & $\$ 272.00$ \\
\hline \multirow[t]{2}{*}{ Install set-back thermostat } & FRN1 & $\$ 47.70$ & $\$ 55.00$ & $\$ 102.70$ \\
\hline & & & Total: & $\$ 5,200.00$ \\
\hline Total General: & $\$ 3,814.02$ & & Remaining: & $\$ 0.01$ \\
\hline \multicolumn{5}{|l|}{ Additional Measure (rafter version): } \\
\hline Description & Component & Labor & Material & Total \\
\hline \multicolumn{5}{|l|}{ Retrofit: } \\
\hline Install R-20 Thermax sandwich (2 layers 1.55 ) & АТT1 & $\$ 2,842.40$ & $\$ 4,263.60$ & $\$ 7,106.00$ \\
\hline & & & & $\$ 0.00$ \\
\hline & & & & $\$ 0.00$ \\
\hline & & & & $\$ 0.00$ \\
\hline & & & & $\$ 0.00$ \\
\hline \multicolumn{5}{|l|}{ General: } \\
\hline & & & & $\$ 0.00$ \\
\hline & & & & $\$ 0.00$ \\
\hline & & & & $\$ 0.00$ \\
\hline & & & & $\$ 0.00$ \\
\hline & & & Combined: & $\$ 12,306.00$ \\
\hline & & & Remaining: & $\$ 2,694.00$ \\
\hline \multicolumn{5}{|l|}{ Additional Measure (Attic Floor version): } \\
\hline Description & Component & Labor & Material & Total \\
\hline \multicolumn{5}{|l|}{ Retrofit: } \\
\hline Cellulose-Loose Blow R-40 11" Settled Density & ATT1 & $\$ 626.64$ & $\$ 895.20$ & $\$ 1,521.84$ \\
\hline & & & & $\$ 0.00$ \\
\hline & & & & $\$ 0.00$ \\
\hline General: & & & & $\$ 0.00$ \\
\hline Vents-Soffit Chutes & ATT1 & $\$ 165.36$ & $\$ 117.00$ & $\$ 282.36$ \\
\hline Install-Pull Floor Boards as necessary for Air Sealing & ATT1 & $\$ 106.40$ & $\$ 0.00$ & $\$ 106.40$ \\
\hline Storage Platform $1 / 2^{n}$ CDX Plywood & ATT1 & $\$ 44.80$ & $\$ 41.60$ & $\$ 86.40$ \\
\hline Storage Platform Insulation Curb 1"x $10^{n}$ & АТT1 & $\$ 25.60$ & $\$ 39.68$ & $\$ 65.28$ \\
\hline Storage Platform Framing 2"x6" & ATT1 & $\$ 0.00$ & $\$ 82.80$ & $\$ 82.80$ \\
\hline \multirow{3}{*}{ Hatch-Install Foam Stair Well Hatch R-30 } & AT1 & $\$ 64.00$ & $\$ 163.80$ & $\$ 227.80$ \\
\hline & & & Combined: & $\$ 2,062.28$ \\
\hline & & & Remaining & $\$ 12,937.72$ \\
\hline
\end{tabular}




\section{References}

AGA (2010). "Residential Natural Gas Market Survey, 2009 Data". American Gas Association.

Baker, Peter (October 2006). "RR-0604: Incorporating Insulating Sheathing into the Design of the Thermal and Moisture Management System of the Building Enclosure". Building Science Corporation. Accessed January 7, 2011: http://www.buildingscience.com/documents/reports/rr0604-incorporating-insulating-sheathing-into-design-of-thermal-and-moisture-managementsystem-of-building-enclosure/view.

BSC (October 2003). "RR-0307: Windows and Occupant Comfort". Building Science Corporation. Accessed January 7, 2011: http://www.buildingscience.com/documents/reports/rr0307-windows-and-occupant-comfort/view.

BSC (November 2006). "Cold Climate: EcoVillage Cleveland". Building Science Corporation. Accessed January 7, 2011: http://www.buildingscience.com/documents/case-studies/csecovillage-cleveland/view.

BSC (May 2009). "Info-301: Drainage Plane/Water Resistive Barrier". Building Science Corporation. Accessed January 7, 2011: http://www.buildingscience.com/documents/informationsheets/3-water-management-and-vapor-control/drainage-plane-water-resistive-barrier/view.

Homes, T.; Hynek, D.; Kramer, T. (2011). “Testing \& Air Sealing Apartment Buildings.” Presentation at 2011 ACI National Home Performance Conference, San Francisco, CA.

Lstiburek, Joseph (June 2005). "BSI-004: Drainage, Holes and Moderation". Building Science Corporation. Accessed January 7, 2011 :http://www.buildingscience.com/documents/insights/bsi004-drainage-holes-and-moderation/view

Lstiburek, Joseph (October 2006). "BSD-105: Understanding Drainage Planes". Building Science Corporation: Accessed January 7, 2011: http://www.buildingscience.com/documents/digests/bsd-105-understanding-drainageplanes/view.

Lstiburek, Joseph (January 2007). "Mold Explosion: Why Now?" Fine Homebuilding. Accessed January 7, 2011: http:/www.buildingscience.com/documents/published-articles/pa-moldexplosion-why-now/view.

Lstiburek, Joseph (June 2008). "RR-0210: Mold Remediation in Occupied Homes". Building Science Corporation., Accessed January 7, 2011: http://www.buildingscience.com/documents/reports/rr-0210-mold-remediation-in-occupiedhomes/view

Lstiburek, Joseph (February 2010). "Attic Air Sealing Guide and Details ". Building Science Corporation. Accessed December 27, 2011: http://www.buildingscience.com/documents/guidesand-manuals/gm-attic-air-sealing-guide/view. 
Straube, John (December 2010). "Future of Window Technology . . .is Here!". Building Science Corporation. Accessed January 7, 2011: http://www.buildingscience.com/documents/publishedarticles/pa-future-window-technology/view.

Ueno, Kohta (December 2010). "RR-1012: Residential Exterior Wall Superinsulation Retrofit Details and Analysis". Building Science Corporation. Accessed January 7, 2011:

http://www.buildingscience.com/documents/reports/rr-1012-residential-exterior-wallsuperinsulation-retrofit/view. 


\section{U.S. DEPARTMENT OF Energy Efficiency \& ENERY Renewable Energy}

